Florida International University FIU Digital Commons

\title{
Dean of the School Board: An Oral History of the Distinguished Career of G. Holmes Braddock
}

Elizabeth Ann Ferreria-Alves

Florida International University

DOI: $10.25148 /$ etd.FI15101387

Follow this and additional works at: https://digitalcommons.fiu.edu/etd

Part of the Educational Administration and Supervision Commons

\section{Recommended Citation}

Ferreria-Alves, Elizabeth Ann, "Dean of the School Board: An Oral History of the Distinguished Career of G. Holmes Braddock" (2001). FIU Electronic Theses and Dissertations. 2329.

https://digitalcommons.fiu.edu/etd/2329 


\title{
FLORIDA INTERNATIONAL UNIVERSITY \\ Miami, Florida
}

\section{DEAN OF THE SCHOOL BOARD: AN ORAL HISTORY OF THE DISTINGUISHED CAREER OF G. HOLMES BRADDOCK}

\author{
A dissertation submitted in partial fulfillment of the \\ requirements for the degree of \\ DOCTOR OF EDUCATION \\ in \\ EDUCATIONAL ADMINISTRATION AND SUPERVISION \\ by \\ Elizabeth Ann Ferreira-Alves
}


To: Dean Linda P. Blanton

College of Education

This dissertation, written by Elizabeth Ann Ferreira-Alves, and entitled Dean of the School Board: An Oral History of the Distinguished Career of G. Holmes Braddock, having been approved in respect to style and intellectual content, is referred to you for judgment.

We have read this dissertation and recommend that it be approved.

Betty Morrow

Linda Spears-Bunton

Peter Cistone, Major Professor

Date of Defense: November 26, 2001

The dissertation of Elizabeth Ann Ferreira-Alves is approved.

Dean Linda P. Blanton

College of Education

Florida International University, 2001 
(C) Copyright 2001 by Elizabeth Ann Ferreira-Alves

All rights reserved. 


\section{DEDICATION}

I dedicate this dissertation to my husband, Celso Ferreira-Alves, and my three children, Nicholas, Philip, and Julia, for their enduring patience, understanding and loving encouragement during this long project. I also dedicate this dissertation to my parents, who instilled in me a deep respect for education and an ardent desire to achieve academic success. 


\section{ACKNOWLEDGMENTS}

I would like to thank and acknowledge the members of my committee for their incredible support and guidance during this study. Dr. Linda Spears-Bunton demonstrated a true understanding of oral history techniques and continually challenged me to go beyond the surface of the data to find its essence. Dr. Betty Morrow provided me with invaluable guidance on qualitative methodologies and kept me grounded in their

purpose. As chair of my committee, I would like to especially acknowledge Dr. Peter J. Cistone who initially encouraged me to enroll in the doctoral program at FIU and who served as my informal advisor throughout my coursework. Dr. Cistone's interest and enthusiasm for educational politics and policy sparked my own curiosity in the subject, and his knowledge of the Miami-Dade Public School system provided me with significant insights throughout this study.

I would also like to especially acknowledge and thank Mr. G. Holmes Braddock and his wife Virginia for sharing their lives with me during this project. The evenings spent in their home will always be special memories for me, as will the many lessons learned from this oral history research project. 


\title{
ABSTRACT OF THE DISSERTATION \\ DEAN OF THE SCHOOL BOARD: AN ORAL HISTORY OF THE \\ DISTINGUISHED CAREER OF G. HOLMES BRADDOCK
}

by

\author{
Elizabeth Ann Ferreira-Alves \\ Florida International University, 2001 \\ Miami, Florida \\ Professor Peter J. Cistone, Major Professor
}

Effective school board leadership is often an ephemeral ideal in today's highly politicized public education arena. However, effective leadership is necessary in order to ensure a fair and equitable education for all students. This dissertation described and explained one school board member's perspective of his career as a lens from which to view and assess public educational policy making in Miami-Dade County.

Now retired after thirty-eight years of service, G. Holmes Braddock is the longest serving, contemporary, urban school board member in the country. Spanning nearly four decades, his perspective provides a comprehensive view of urban education both locally and nationally. The significance of his longevity and the impact of his leadership on educational policy-making was the focus of indepth interviews with Mr. Braddock and other key educational "influentials." From this transcript data, recurring themes were revealed and categorized. Five elements of his perspective, i.e., teacher professionalization; desegregation; athletics; bilingual education; and his comprehensive leadership role, were identified and analyzed, as were five variables of his perspective, 
i.e., fairness; integrity; honesty; courage; and the situational context. Other secondary source material, such as excerpts from newspaper articles, school board minutes, and items from Mr. Braddock's own personal effects further augmented and triangulated the data.

Given that the purpose of this study was to describe and explain Mr. Braddock's perspective of his school board career, the findings can be understood from two different viewpoints. The elements of Mr. Braddock's perspective describe or characterize his career and represent the significant policy issues in which he demonstrated exceptional vision and leadership. However, taken alone, these elements cannot fully explain his distinguished career. Rather, an analysis of the variables of Mr. Braddock's perspective provides an explanation for the effectiveness of his leadership role. Personality traits such as fairness, integrity, honesty and courage and the impact of the situational context were factors that strongly influenced Mr. Braddock's decision-making. Thus, Mr. Braddock's school board career can be holistically understood as the intersection of person, place and time with significant public education policy issues.

The results of this study provide a unique and historical perspective of school board politics in Miami-Dade County. From Mr. Braddock's perspective, we are able to view one individual's leadership role over time and its impact on local public education policy. 


\section{TABLE OF CONTENTS}

CHAPTER

PAGE

I. INTRODUCTION

Context of the Study

Purpose of the Study

Rationale for the Study

Assumptions of the Study

Limitations of the Study

Summary of the Chapter

II. REVIEW OF RELATED LITERATURE 9

Teacher Professionalization $\quad 10$

$\begin{array}{ll}\text { Historical Context } & 10\end{array}$

The Role of Unions in Teacher Professionalization $\quad 11$

Teacher Professionalization in Miami-Dade County 13

Contemporary Issues for Teacher Professionalization 16

$\begin{array}{ll}\text { Desegregation } & 21\end{array}$

Historical Context $\quad 21$

Rationale for School Desegregation $\quad 22$

$\begin{array}{ll}\text { Other Benefits } & 24\end{array}$

Current Status of School Desegregation $\quad 24$

Desegregation in Miami-Dade County 25

Recent National Trends $\quad 27$

Recent Trends in Miami-Dade County $\quad 29$

Future Desegregation Trends $\quad 30$

Athletics $\quad 31$

Historical Context $\quad 31$

Rationale for Athletic Programs in Schools $\quad 32$

Other Benefits $\quad 34$

Current Trends in Athletics $\quad 35$

Athletic Trends in Miami-Dade County $\quad 37$

Bilingual Education $\quad 38$

Rationale for Bilingual Education $\quad 39$

Current Trends in Local Bilingual Education Initiatives 40

Comprehensive Leadership Role $\quad 42$

Leadership Defined $\quad 43$

$\begin{array}{ll}\text { Leadership Theories } & 44\end{array}$

Summary of the Chapter $\quad 48$

III. METHODOLOGY $\quad 50$

Preparation $\quad 51$

Description of the Participants 51

G. Holmes Braddock $\quad 51$ 
Dr. Wayne Blanton $\quad 52$

Dr. Joseph Fernandez $\quad 52$

Janet McAliley

Alan Olkes $\quad 53$

Pat Tornillo $\quad 53$

Octavio Visiedo $\quad 53$

Data Collection $\quad 54$

Data Analysis $\quad 55$

Presentation of the Data $\quad 57$

The Role of the Researcher $\quad 57$

Summary of the Chapter $\quad 59$

IV. RESULTS 60

Findings $\quad 60$

Organizational Framework for Analysis 61

The Elements of Mr. Braddock's Perspective 62

Teacher Professionalization $\quad 62$

Desegregation $\quad 68$

Bilingual Education $\quad 80$

Athletics $\quad 84$

Comprehensive Leadership Role $\quad 87$

The Variables of Mr. Braddock's Perspective 100

Fairness 101

Integrity 115

Courage 124

Honesty 131

Situational Context 134

Summary of the Chapter $\quad 141$

Elements of His Perspective 141

Teacher Professionalization $\quad 142$

Desegregation $\quad 142$

Bilingual Education $\quad 142$

Athletics 143

Comprehensive Leadership Role $\quad 143$

Variables of His Perspective $\quad 143$

Fairness 144

Integrity 144

Courage 144

Honesty 145

$\begin{array}{ll}\text { Situational Context } & 145\end{array}$

V. CONCLUSIONS AND IMPLICATIONS 146

Discussion $\quad 146$

Conclusions 148

Teacher Professionalization $\quad 149$ 
Desegregation

Bilingual Education

Athletics

Comprehensive Leadership Role

151

Implications

LIST OF REFERENCES 


\section{CHAPTER I}

\section{INTRODUCTION}

The purpose of this study was to describe and explain Mr. G. Holmes Braddock's perspective on his thirty-eight year school board career. Through the use of indepth interviews with Mr. Braddock and other educational "influentials," key elements and variables were revealed in the data. These key elements and variables were supported with excerpts from newspaper articles, school board minutes and items from Mr. Braddock's own personal effects. In this manner, triangulation of the data was achieved.

This chapter presents the background that establishes the context for the study, the purpose and rationale for this research, and the assumptions and limitations inherent in the study.

\section{Context of the Study}

The Miami-Dade County Public School system is the fourth largest school district in the United States. At present, it serves approximately 368,000 urban students of various backgrounds and cultures. According to 2000-2001 Miami-Dade County Public Schools statistics, $56 \%$ of the district's students are Hispanic, $31 \%$ are Black (the terms Black and African-American are used interchangeable throughout the study to denote people of color of African descent), $11 \%$ are White non-Hispanic, and $2 \%$ are listed as Other (Miami-Dade County Public Schools Statistical Highlights, 2001).

Demographic statistics of Miami-Dade County reveal that out of its two million residents, $57.4 \%$ speak no English at home. Further, an estimated $45.1 \%$ of the county's population was born outside of the United States (U.S. Census, 2000). Combined, these 
statistics illustrate the fact that the Miami-Dade Public School system is one of the most complex and diverse systems in the country.

Until recently, a seven-member board governed the Miami-Dade County Public Schools. These partisan members held four-year terms of office and were elected by the community at large. Beginning in the early 1960's, the demographics of Miami-Dade County changed dramatically from a majority White, non-Hispanic population to its present-day Hispanic majority. However, the composition of the school board did not, leading many to question whether the board truly represented its constituency.

This has not been a problem that is unique to Miami. According to Danzberger, Kirst, and Usdan (1992), there have been many recent debates over minority representation and school board compositions in large, urban school districts across the country. And while the fear of parochial political practices during the early part of the century initiated the tradition of district wide school board elections, it is the need for more community participation today that has fostered the impetus toward single member district elections. This occurred in Miami-Dade County in 1996 when voters elected a nine-member school board from single member districts.

The result of this transition to a nine-member board was a change in its composition. Over the past thirty years the board had had representation from both the local Black and Hispanic communities. However, the change in composition due to single member district elections in 1996 made the board more representative of the demographics of Miami-Dade County (four Hispanics, three Whites, two Blacks). The leadership of the board at the initiation of this study (1998) was held by a Black chair and a Hispanic vice-chair, and although minority leadership has been present in the past, 
much of the recent board agendas have tended to reflect more parochial interests. How these changes will fully impact the district and what the final outcome of these changes will be can only be surmised. But through all of these changes, one person has remained constant. Mr. G. Holmes Braddock, who until his voluntary retirement from the board in 2000 , served for thirty-eight consecutive years as a member of the Miami-Dade County School Board.

As a school board member with thirty-eight years of service in a large urban district, Mr. Braddock is an anomaly. Research indicates that the majority of today's school board members have three or fewer years of experience, while just over a third of all members have served for seven or more years (American School Board Journal, 1996). Don Blom, Associate Executive Director of the National School Boards Association, estimates that the current longevity of a board member is only about $1 \%$ or less. Further, to his knowledge there is no one else in a big city system or a major urban district that has served as many years as Mr. Braddock.

In Florida, only two other board members can exceed Mr. Braddock's longevity. Mr. Beauford E. Davidson of Hendry County has served as a board member since 1960 and Mr. James Boland, Jr. of Jefferson County has served since 1962 (Fiedler \& de Haven, 1998). However, in both instances these board members serve in rural counties where the total population in each is one-quarter the size of one region in the M-DCPS system. Further, as Fiedler and de Haven (1998) observe, in these rural counties political change comes very slowly. Therefore, while these school board members may have accrued equal years of service, neither of these members have done so in a political climate like Miami's. Thus, Mr. Braddock's achievements seem even more significant. 
Why are there so few school board members who can claim the longevity of service equal to that of Mr. Braddock? The American School Board Association suggests that "school boards are often the targets of parents, politicians, and special interest groups who expect the nation's public schools to solve America's troubles" (American School Board Journal, 1996, p. A19). The result is often "an atmosphere in which it's becoming tougher to get re-elected and easier to be recalled" (American School Board Journal, 1996, p. A19).

Given the highly political environment in Miami-Dade County, it is particularly noteworthy that Mr. Braddock was re-elected for ten terms of office as a school board member. What factors have contributed to Mr. Braddock's longevity on the board? What significance has his longevity had on school board politics, policies and decisionmaking? What can be learned from his leadership and service on the school board? These were just some of the questions that were explored in this study.

\section{Purpose of the Study}

The purpose of this study was to describe and explain through an oral history, $\mathrm{Mr}$. G. Holmes Braddock's perspective on his career as a member of the Miami-Dade County School Board. Two key exploratory questions guided this study. They were:

1. What elements constituted Mr. Braddock's perspective?

2. What variables influenced Mr. Braddock's perspective?

$$
\text { Rationale for the Study }
$$

If one were to analyze the significant changes that our country has undergone since the early 1960 s, each change would be reflected to some degree in our local school community. From desegregation to the women's movement, from majority rules to 
minority rights, from centralization to shared decision-making, the Miami-Dade Public Schools system has responded to societal changes that have occurred locally, nationally, and internationally. Using Grodzin's (1966) marble cake metaphor, local policy is often the result of filtering and intermingling of politics at various levels of government. How individuals influence school board policies and politics is idiosyncratic to the situation and the locale. However, as Scribner and Layton (1995) point out individual school board member's values do impact policy in significant ways, as do individual motivations (Dahl, 1991).

With this in mind, it is also important to note the role that school plays within society. According to Wirt and Kirst (1992), school is the dominant institution in society. As such, decisions made at the local school level with relation to what is taught and who is taught, have significant import to the larger society. Who makes those decisions and the values and motivations that influence these decisions are central to this issue.

Although they are often viewed by parents as elected representatives who should be responsive to their constituents, school board members are in fact state officials "empowered by the state to perform a state function - governing the public schools - at a local level" (Greene, 1990, p. 364). Continually challenged by often conflicting demands, many school board members find their service to be frustrating and unfulfilling. Given the highly political nature of the position and the often overwhelming challenge of meeting conflicting constituent demands, the turnover rate among school board members is high. This calls into question the effectiveness of these governing bodies and their ability to provide the level of leadership that is needed to meet the needs of our changing society. 
As a thirty-eight year incumbent on the Miami-Dade County School Board, Mr. Braddock learned how to survive the political realities of the job. How he came to serve on the board and what the contributing factors were that kept him there over time provide a perspective on his success. Through this study, insights into how the local school board is influenced by individual values, events, and/or personal motives, and how external forces have contributed to shape the current system were also revealed. Moreover, Mr. Braddock's leadership and impact on policy during particular moments in our local history serve as significant guideposts for better understanding contemporary challenges and opportunities for public service.

\section{Assumptions of the Study}

Inherent in every study are assumptions that influence the selection of methodology for both data collection and analysis. Assumptions relevant to this study are as follows:

1. Qualitative methods were deemed to be the most appropriate means of gathering information that described and explained Mr. Braddock's perspective on his school board career.

2. Interview data collected from Mr. Braddock reflected a personal perspective on his career. However, triangulation of this data with other sources such as key educational "influentials," newspaper articles and evidence from $\mathrm{Mr}$.

Braddock's own personal effects established the reliability and truthfulness of his perspective on his school board career. 
3. Interview data obtained from other key educational "influentials," was assumed to be truthful since their participation in this study was completely voluntary.

\section{Limitations of the Study}

The scope of a particular research project is always limited by certain variables. The limitations that impacted this study and are outlined below:

1. The primary interviews conducted with Mr. Braddock occurred over a period of two years. Due to his changing role on the school board, the perspective provided during these sessions may have changed somewhat as well.

However, because of the comprehensive nature of the interviews, the data proved to be consistent overall.

2. Secondary interviews were limited to six key educational "influentials." While these individuals represented a diverse perspective on Mr. Braddock's school board career, they certainly did not represent all perspectives.

3. No African-American was interviewed as part of the secondary interviews. However, several influential African-American perspectives were obtained from print sources and were included in the data. With the overwhelming preponderance of data from various sources substantiating Mr. Braddock's perspective, this limitation did not appear to be significant.

4. The role of the qualitative researcher is instrumental in the research process itself. Therefore, my own personal admiration and respect for Mr. Braddock must be acknowledged as a possible bias. However, each observation made in 
the presentation and analysis of the data was supported by the findings, thereby minimizing any personal interpretation.

\section{Summary of the Chapter}

Chapter I provided an overview of the research. A demographic view of MiamiDade County and its public school system established a context for the study. The political ramifications of school board policy making and the key role of governing school boards to directly influence curriculum and instruction established the rationale for the study. Additionally, the longevity of Mr. Braddock's career as a member of the Miami-Dade School Board in relation to the careers of other urban school board members provided the purpose for the study. Two key exploratory questions were identified to guide the qualitative study. Finally, several assumptions that are inherent in qualitative research were identified, as were limitations that may have influenced the interpretation of the results of the study. 


\section{CHAPTER II}

\section{REVIEW OF RELATED LITERATURE}

A review of the literature for this study focused on the five elements identified in the data presentation and analysis of Mr. Braddock's perspective. These elements were teacher professionalization, desegregation, athletics, bilingual education, and $\mathrm{Mr}$. Braddock's comprehensive leadership role. Four of these elements: teacher professionalization; public school desegregation; athletics and bilingual education represented significant public education issues during his tenure.

As will be illustrated in the presentation and analysis of the data in Chapter IV, each of the four elements was interconnected by five underlying variables, i.e., fairness, honesty, integrity, courage, and situational context, which influenced Mr. Braddock's position on the issues. Combined, the five variables and the four elements of Mr. Braddock's perspective provided a holistic assessment of his school board career that defines the fifth element of his perspective: his comprehensive leadership role.

The first part of this review of the literature focused on each of the four elements that represented significant policy issues for public education during Mr. Braddock's tenure as a member of the Miami-Dade County School Board. Each of these elements was reviewed from an historical perspective with contemporary issues identified and discussed for their current significance on today's educational policy making. These elements are reviewed in the order that they are presented in Chapter IV.

The second part of the review of the literature focused on Mr. Braddock's comprehensive leadership role. A review of contemporary leadership theories was conducted to illustrate the influence of the five variables of Mr. Braddock's perspective 
on his comprehensive leadership role. In this manner, the relevance of the variables of Mr. Braddock's perspective was demonstrated in the context of leadership theory.

In summary, the purpose of this review of the literature was to establish the significance and relevance of the findings presented in the presentation and analysis of data, i.e., the elements and variables of Mr. Braddock's perspective.

Teacher Professionalization

Throughout the interviews with Mr. Braddock, the issue of teacher professionalization was a pervasive topic. From both a personal and professional perspective, Mr. Braddock communicated a sincere respect for the teaching profession and demonstrated his ongoing support of professionalization efforts.

During his thirty-eight year tenure on the Miami-Dade County Public School Board, Mr. Braddock gained an intimate understanding of the issues related to teacher professionalization. Through his longevity and his participation in state and national organizations, Mr. Braddock was able to view the evolution of local professionalization efforts in a holistic manner. Thus, this review of the literature discusses the teacher professionalization movement in Miami-Dade County in the context of state and national trends.

\section{Historical Context}

Historically, the professionalization of teaching is a relatively new development in America's public school systems, primarily evolving during the past century. Webster defines the term professionalism as "the conduct, aims, or qualities that characterize or mark a profession or a professional person" (Webster's New Collegiate Dictionary, 1976). Under this definition, initial efforts to professionalize teaching were aimed at the 
establishment of common professional preparation, qualifications and educational goals that would standardize the workforce and govern professional behavior (Nusser, 1996).

In later years, this initial definition was expanded as teachers sought to improve their work conditions. Union activity and collective bargaining focused on improving work conditions, better benefits, and greater autonomy in the classroom as teachers called for recognition as professionals who possessed "a specialized body of knowledge or skill, the acquisition of which necessitates extensive training... and dedication over a long period of time," (Nusser, 1996, p. 20). In this manner, teachers viewed themselves as professionals simply because of their specialized knowledge and training

More recently, teacher professionalism has evolved into an emphasis on "the quality of practice." According to Sockett (1996), this "quality of practice" does not refer to knowledge or technique, but rather to a moral responsibility that teachers have to the students in their classrooms (p. 23). Further, as professionals, teachers have a responsibility to the continued improvement of the profession (Feldman, 1998). Therefore, today's teacher professionalization efforts largely focus on continual professional growth and collaboration in order to "uphold the highest professional standards" (Kerchner, Koppich, \& Weeres, 1998, p. 21).

The Role of Unions in Teacher Professionalization

Beginning at the turn of the century, the teacher professionalization movement was influenced by industrial labor models. Encouraged by the successes of other labor unions, classroom teachers recognized the need to form "a new national organization that would be committed to their professional interests" (American Federation of Teachers, May, 2001). In 1916, the American Federation of Teachers was founded to improve the 
existing working conditions for public school teachers, to improve salaries and benefits and "to create strong local unions affiliated with the labor movement (American Federation of Teachers, May, 2001). As a result of this emphasis, "teachers were treated as technicians and were employed to carry out the managerial/political will in terms of curriculum and instruction rather than moral agents entrusted with the care of children" (Sockett, 1996, p. 22). This perspective reflected the top down orientation of management prevalent in large industrial organizations during this time.

As professionalization efforts continued to evolve, teachers' unions across the country fought for collective bargaining rights (American Federation of Teachers, May, 2001) during the sixties. In many instances, this effort culminated in teacher walkouts, boycotts and strikes. Also, in response to the "red scare" of the McCarthy era, teachers fought for more autonomy in the classroom and their rights to academic freedom (United Teachers of Dade, May, 2001). In addition to collective bargaining, union-led professionalization efforts in the 1960's supported the growing Civil Rights Movement. In the aftermath of Brown v. the Board of Education, the AFT and other local affiliates supported public school desegregation and faculty integration (American Federation of Teachers, May, 2001).

The decade of the eighties brought the changes in the professionalization movement that are still evident today. As a result of the publication of $A$ Nation At Risk in 1983, Albert Shanker, then AFT president, called for a "union of professionals" that would exemplify high standards (Kerchner, Koppich, \& Weeres, 1998, p. 21). Under this reform model, teacher unions would support increased professional training for teachers, 
career redirection for incompetent teachers and school choice for parents and students (Kerchner, Koppich, \& Weeres, 1998).

Today's contemporary efforts for professionalization reflect Albert Shanker's vision. He and others believe that today's information-laden society demands that schools become "learning organizations" (Sockett, 1996, p. 22) where "educational solutions will be created from the classroom up rather than assembled centrally and handed down" (Kerchner et al., 1998, p. 23). Today, under Sandra Feldman's leadership, "the American Federation of Teachers is on a quest to increase teacher effectiveness from professional development to peer assistance" (Feldman, 1998, p. 19). Teaming with the NEA, both unions presently support a shift from the "industrial union model to a craft-and-guild union model" (Black, 2000, p. 59). In this new model, "union members take an active role in 'policing their profession' and have a say in deciding which employees meet quality standards" (Black, 2000, p. 59). This shift in orientation from top down management to more participatory management is reflected in today's contemporary organizational theory.

Teacher Professionalization in Miami-Dade County

Like its national counterparts, the rise of the local teachers' union was primarily based on an effort to improve working conditions and wages for classroom teachers. Founded in 1930, the Dade County Classroom Teachers Association "adopted, as a major objective, the improvement of the personal and professional status of teachers," (United Teachers of Dade, May, 2001).

In the 1940's, the CTA supported increased teacher preparation in its continued effort towards professionalization. With the new minimum requirement of a four-year 
degree, the union also sought to improve salaries, establish tenure, and provide sick leave benefits (United Teachers of Dade, May, 2001). In 1962, today's Executive Director, Pat Tornillo, "ran for the union presidency, with merger of the separate black and white teacher organizations as a major plank in his platform" (United Teachers of Dade, May, 2001). He won the election in a close race and began his long tenure with the CTA, the forerunner of today's United Teachers of Dade.

Salary disputes and labor negotiations marked the later half of the sixties. In 1965, fear of a proposed "boycott of summer school and curtailment of extracurricular activities" resulted in "the largest salary increases" that Miami-Dade County public school teachers had ever received (United Teachers of Dade, May, 2001). In 1968, Dade County's teachers participated in a statewide walkout, again protesting unfair salaries and poor working conditions. Their political actions resulted in state legislation that gave provisions for collective bargaining.

In the 1970's, the CTA played an active role in the faculty desegregation that was court ordered by Judge C. Clyde Atkins. In addition, during this decade, the CTA merged with the Dade Federation of Teachers to form today's United Teachers of Dade. Professionalization initiatives continued to focus on salary issues and work place improvements. (United Teachers of Dade, May, 2001)

Local professionalization efforts in the eighties mirrored those on the national level. The publication of $A$ Nation At Risk had drawn alarming attention to the status of the public school system in America, and reform efforts were focused on ways to improve. Initiatives such as shared decision-making and site-based management were supported by UTD and assured classroom teachers a new role in schools as professionals. 
Most recently, the paradigm shift for teacher professionalization initiated at the national level has been reflected in local efforts. The need for ongoing teacher professional development is now reflected in locally implemented annual performance plans. Additionally, the national call for peer review and peer assistance is currently reflected in the county's new assessment and evaluation tool, Professional Assessment and Comprehensive Evaluation System, referred to as PACES. With PACES, an emphasis on developing students' thinking skills, promoting reflective practice and peer assessment requires a new level of professionalism among teachers.

In summary, the teacher professionalization movement in Miami-Dade County has been integrally tied to the local union. Like its national counterparts, the CTA and UTD have continued to drive professionalization efforts forward in Miami-Dade County. What initially began as an effort to improve working conditions and wages for teachers has now become part of a major effort to reform public education in America today. Through its evolution, the concept of teacher as a professional has changed from one who possesses technical proficiency to one who possesses knowledge, true craftsmanship and artistry (Kerchner et al., 1998). And while many blame low salaries as a deterrent to attracting a highly qualified workforce, today's unions realize that they play an important role in ensuring high quality education in today's schools (Black, 2000; Feldman, 1998; Kerchner et al., 1998; Sockett, 1996).

National statistics predict an alarming shortage of teachers across the country over the next decade. Issues of professionalism are integrally related to the ability of local school boards to attract and employ qualified educators to meet the demands of increasing student enrollment. Thus, an indepth understanding of contemporary issues 
related to teacher professionalization is needed in order to promote professionalization efforts.

\section{Contemporary Issues for Teacher Professionalization}

As previously discussed from a historical perspective, teacher professionalization has changed over time to reflect the national trends in public education. And while local and national unions continue to advocate for better salaries and benefits in an effort to recruit and retain teachers necessary to meet the needs of an anticipated national teacher shortage, the profession also recognizes a need for improving the quality of instruction in the public schools in order to renew the public's trust in their local school systems.

"Critics have cited teacher unions as an obstacle to getting rid of incompetent teachers" (Feldman, 1998, p. 20). In addition, contemporary political rhetoric has centered on America's failing schools, with calls for reform. In response, today's professionalization efforts are focused on three pertinent issues as a means of improving student performance and counteracting the public's mistrust.

Shared decision-making vs. community of learners. Begun in the 1980's, the concept of shared decision-making was established as a means of empowering teachers and improving schools. Recognizing that "this practice of involving faculty and developing consensus increases morale, develops a sense of institutional culture and community, improves work motivation, and creates support for administrative actions" many school districts, including Miami-Dade County, implemented school-based decision-making (Miller, 1996, p. 7). In theory, the school-based shared decision-making model provided opportunities for teachers and administrators to form committees or cadres to assess school-site needs and develop plans to address those needs. In practice, 
many of these reform efforts failed. Confusion over roles and responsibilities, poor preparation, and lack of time and training contributed to the limited success of this initiative.

Today, there is a resurgence of interest in school-site shared decision-making. While in the past the focus was on school policies and budgets, today's initiatives are focused to "build partnerships with administrators, [to] work to enhance school quality and help incompetent teachers improve - or remove them from the classroom" (Kerchner et al., 1998, p. 21) in an effort to give "teachers both authority and responsibility for reform" (p. 23). In this new community of learners, teachers must take responsibility for their profession "to ensure high standards... and a restructured education system that would transform teachers from dispensers of knowledge to coaches for students, supervisors of novice teachers, and organizers of the school program" (Kerchner et al., 1998, p. 21).

Stated another way, Sockett (1996) asserts that "professional teachers must be capable of profound reflection on practice; competent to enter into a dialogue of the practice they know and the theory or literature they read; able to engage in teacher community of interpretation and critique with colleagues and with children; and able to observe, document, and analyze their own practice and experience, and take that analysis into the white hot cauldron of public forums and public accountability" (p. 26). Through collaboration and collegiality with all stakeholders in the educational community, it is suggested that professional teachers will possess equal status with administrators in the efforts to reform and revitalize public education in America. 
Academic freedom and peer review. Inherent in the term professionalism is the belief that individuals within a profession possess the knowledge and skills needed to competently perform a job. Implied in this belief is the idea that professionals can and should decide what actions are needed to achieve a particular goal. Thus, closely tied to any discussion of teacher professionalism is the concept of academic freedom.

As defined, academic freedom "concerns what is taught and/or how it is taught" (Strope, 1999, p. 14). With the belief that "reason, if left free, could discover useful knowledge" (Hamilton, 1997, p. 16), the court found in the 1967 Supreme Court case of Keyishian v. Board of Regents that "teachers and students must always remain free to inquire, to study and to evaluate, to gain new maturity and understanding; otherwise our civilization will stagnate and die" (Strope, 1999, p. 15). With this case as its foundation, the concept of academic freedom as applied to the classroom was established.

Throughout the sixties and seventies, cases involving academic freedom continued to receive judicial support for teachers. In both Keefe and Mailloux, the court considered the relevance of the curriculum as well as the age and maturity of the students in reaching a decision in favor of the teacher. However, in the 1980's, a more conservative tone began to govern court decisions. The rights of teachers to use provocative material were assessed against the rights of school boards to establish guidelines for appropriate and acceptable student behavior. Recent court decisions in the nineties such as Lacks and Boring have continued this trend (Russo \& Delon, 1999; Strope, 1999).

In response to this challenge to academic freedom and allied with the professionalization movement, peer review has been suggested as a means of "handling 
scholarly misconduct" (Stichler, 1997, p. 22). According to Stichler's (1997) assessment of academic freedom and tenure at institutions of higher learning, "if we are to justify our claim to academic freedom and professional autonomy, we ought to be able to demonstrate by our record that we do ensure compliance with the standards by which we profess to be governed" (p. 21). This rhetoric sounds familiarly similar to Albert Shanker's call for "a professional teacher board to ensure high standards and rid the profession of those who did not measure up" (Kerchner et al., 1998, p. 21) and Hamilton's (1997) assertion that "peer review is the linchpin of academic freedom" (p. $15)$.

If we believe, like Sockett (1996), that "teaching in contemporary society demands both high academic standards and great moral and practical sophistication" (p. 26), then the profession must acknowledge and accept responsibility for the quality of teaching in our schools today. "Peer review is probably the most powerful demonstration of teacher knowledge of practice and commitment to high professional standards" (Kerchner et al., 1998, p. 23) and provides an essential mechanism for enhancing the profession.

Peer assistance/evaluation. A final hallmark of contemporary professionalization efforts is peer assistance and/or evaluation. Tied to the belief that schools should become communities of learners in which teachers play an important role in developing and policing their profession, peer assistance and/or evaluation is a grassroots effort to achieve this goal.

Recent research has illustrated the need for many teachers to "retool" their methods of instruction. However, "typical staff development approaches, especially the 
familiar one-shot workshop, do not result in improved teaching practices" (Feiler, Heritage \& Gallimore, 2000, p. 66). Rather, what is needed is "ongoing professional interactions with colleagues" and "on-site expertise and leadership" (Feiler et al., 2000, p. $66)$

This "power of peers" is cited by both the National Educators' Association and the American Federation of Teachers (Chase, 1998, p. 20). According to the AFT, its members are "on a quest to increase teacher effectiveness - from professional development to peer assistance" (Feldman, 1998, p. 19). Both unions recommend "peer assistance, in which consulting teachers act as mentors, helping other teachers improve their knowledge and skills" and "peer review, in which consulting teachers conduct formal evaluations and make recommendations regarding tenure and other employment conditions (Black, 2000, p. 59). In both peer assistance and peer review, enhancing the quality of instruction is of paramount importance and is a collaborative process between teachers and administrators.

In summary, contemporary teacher professionalization efforts are primarily focused on ways to enhance public education and improve student achievement through professional collaboration, assistance and peer evaluation. Like other professionals, it is suggested that educators must take responsibility for their profession and play an active role in preserving its integrity.

From this review, it is apparent that issues related to teacher professionalism are as significant today as they were in 1962 when Mr. Braddock first ran for the local school board. While the issues inherent in this aspect of public education have changed over time, the relevance of these issues to school board policymaking have not changed. 


\section{Desegregation}

As noted in the transcripts from the interviews with Mr. Braddock, the desegregation of the public schools in Miami-Dade County was the most significant of the four elements found in the data. It is acknowledged that his own leadership role as chair of the school board at this time made Mr. Braddock the "point man" for much of the debate that surrounded this issue. However, the desegregation of the public schools in Miami was only part of a national effort. Thus, the review of the literature on this issue begins with a historical perspective.

\section{Historical Context}

Prior to the historic Brown v. Board of Education decision, the public schools in America were largely segregated. Under the "separate but equal" doctrine established in Plessy v. Ferguson, states could legally operate separate public school facilities for black and white students. However, in 1954, the Supreme Court's decision in the Brown case found that "separate educational facilities are inherently unequal" and therefore Black students were not receiving equal treatment under the law as intended in the Fourteenth Amendment (Brown v. Board of Education, 1954).

In the years following the Brown decision, progress toward school integration was slow and met strong resistance. Efforts to integrate were often met with violence and intimidation. However, with the passage of the 1964 Civil Rights Act, the federal government took a strong stand in support of integration and by the early 1970's most urban school districts were implementing school busing plans in order to comply with the law (Orfield, Bachmaier, James, \& Eitle, 1997). 


\section{Rationale for School Desegregation}

In the Brown v. Board of Education case, the opinion of the Supreme Court delivered by Chief Justice Warren provided the initial basis for school desegregation in America. The court found that separate but equal school facilities were "inherently unequal" and that the policy of segregation implied that Black children were inferior. In the court's opinion, "segregation with the sanction of the law, therefore, has the tendency to [retard] the educational and mental development of Negro children and to deprive them of some of the benefits they would receive in a racial[ly] integrated school system" (Contreras \& Stephens, 1997, p. 183). Thus, it was believed that the physical integration of America's public schools would ensure equal opportunities for all students (Brown v. Board of Education, 1954).

In the years since this historic court decision, research on the impact of desegregation has consistently shown the academic gains of Black students who are schooled in an integrated setting. According to Samuel Harvey, Jr., Vice President for Urban Affairs at Georgetown University, school desegregation has led to increased academic success for African American students. In a speech given in a 1993 Woodstock forum, he cited "enormous progress in high school completion, in better test scores, in greater college enrollment, in obtaining college degrees and in careers" on the part of African American students from desegregated schools (Woodstock Report,1993, p. 3). In fact, research reveals that Black students perform better in desegregated schools than in racially isolated schools (Willie, 1999).

These findings are substantiated by the work of Gary Orfield. In court testimony, Orfield cited the effect of the "peer group" as a major contributor to academic success for 
minority students in desegregated schools (Orfield, 1997, p. 248). In a 1998 study on the effects of a voluntary integration program in Boston called METCO, most Black students reported a "virtually unanimous intention of completing college" (Orfield, 1998, p. 9).

Over the long run, academic gains translate into increased economic opportunities. In a longitudinal study by William Trent (1997), significant economic benefits for minority students enrolled in racially integrated public schools were reported. His research indicated that "desegregated schooling has a positive, statistically significant benefit for Black students' later earnings and occupational attainment" (Trent, 1997, p. 255). Further, Trent (1997) found that "students attending the same school are likely to participate in the same information networks and thus to have similar opportunity paths and resultant outcomes" (p. 257). These findings suggest that school integration contributes to both educational and economic opportunities for Black students.

The significance of these findings is acknowledged by Orfield. He suggests that "the consequences of education have become steadily more important in the 1980's and 1990 's, as the economy is transformed and the good jobs that don't require education have vanished" (Orfield, 1997, p. 246). This is significant when you consider that "Blacks who work in settings with White coworkers hold jobs that rank higher and pay better than those held by Blacks who attended single-race schools" (Trent, 1997, p. 257). Further, Trent's research (1997) revealed that, "the likelihood that Blacks will have White coworkers and that Whites will have Black coworkers" (p. 256) is directly correlated to school integration. Thus, desegregation can be viewed as a means of ensuring more equitable occupational opportunities. 


\section{Other Benefits}

The value of desegregation appears to extend beyond academic and economic considerations. In an article by Michael Kurlander and Gary Orfield (1999), "students who experience diversity in classroom settings and in informal interactions on campus show the most engagement in various forms of citizenship, and the most engagement with people from different races and culture" (p. 32). In the research of Dutton, Singer and Devlin (1998), "children from integrated schools chose opposite race friends more often than did the Black children from the nonintegrated school" (p. 50) suggesting that children in segregated schools "lack the level of acceptance enjoyed by children in the integrated schools" (p. 51).

These findings are further substantiated by Gary Orfield. In his METCO study, students reported that "their positive experiences [were] commonly related to interracial friendships and less racial self-consciousness" (Orfield, 1998, p. 10). And both parents and students reported the positive benefits of "learning to live and work in a diverse interracial setting" (Orfield, 1998, p. 9). As we continue to promote positive race relations in America, these findings suggest that public school desegregation offers significant benefits to the students who attend desegregated schools. Current Status of School Desegregation

As a result of the Brown case, school desegregation efforts were primarily focused on the "physical integration of African American and white students through such measures as busing, school choice, magnet schools, use of ratios, redrawn school district boundaries, mandatory and voluntary intra- and interdistrict transfers, and consolidation of city districts with suburban districts" (Weiler, 1998, p. 3). In an effort to 
desegregate America's public schools, "the burden of desegregation fell mostly on African American students and their communities" (Hess, 1998, p. 250). "African American and Latino students were more likely than Anglo students to be bused to schools outside of their neighborhoods" (Margonis \& Parker, 1999, p. 205).

While these efforts successfully met the mandated quotas for integration, many believe that a cultural segregation persisted. Even when desegregation was achieved, "claims persist that segregation still continues under the guise of school tracking and grouping practices" (Weiler, 1998, p. 5). This finding was supported by Margonis and Parker (1999) who found that "African American students were over-represented in educable mentally handicapped classes, under-represented in gifted classes, underrepresented in rates of graduation, and subjected to higher levels of corporal punishment and suspensions than Anglo students" (p. 205). And while more Black students are graduating from high school, performing better on standardized tests, and attending college, Samuel Harvey points out that "the gap between white and African-American achievement remains substantial" (The Woodstock Report, 1993, p. 3).

Desegregation in Miami-Dade County

Like most of the south, school desegregation came slowly to Miami-Dade County. However, in 1969, Federal Judge C. Clyde Atkins ruled that Miami-Dade Public Schools must comply with the law and integrate its school system (Pate v. School Board of Miami-Dade County, Florida, 2001). As noted by Mr. Braddock in the interview transcripts, the faculties, with the assistance and support of the United Teachers of Dade, were integrated first. Then, at the semester break in January, attendance boundaries were redrawn to bus minority students into schools with a majority population, White or Black. 
Reflecting national trends, the brunt of the busing was borne by Black students. An example of this was the twenty-five year practice of busing Black students from Richmond Heights into six different majority White elementary schools outside the community for grades one through five. In contrast, the white students attended their home elementary school and were only bused one year (sixth grade) to Frank C. Martin Elementary School in Richmond Heights.

During this time, some voluntary transfers were encouraged through MajorityMinority transfers, known as $\mathrm{M} \& \mathrm{M}$ transfers. Under this model, voluntary transfers of minority Black students to majority White schools were approved and transportation for these students was provided. However, all of these requests had to be submitted to the area office and reviewed.

In later years, the magnet school concept was created to encourage voluntary integration. Applying this model, schools with majority populations would create special curricular programs to "attract" voluntary minority student participation as a means of further integrating the school. Since its inception, the magnet school concept in Miami-Dade County has grown to encompass 78 schools (Miami-Dade County Public Schools Statistical Highlights, 2001). While many of these programs have successfully achieved their intended purpose, the costs of providing specialized materials and facilities and transportation costs drain valuable resources from the county as a whole. Additionally, many critics of these programs suggest that the practice of recruiting the best and brightest for participation in these programs depletes the number of high achieving students in the home school, thereby limiting that school's ability to offer a challenging curriculum. 


\section{Recent National Trends}

Desegregation in today's public educational arena is undergoing significant changes. According to the Jeanne Weiler (1998), "one of the most prominent current trends is the increasing number of court cases which release school districts from court supervision of their desegregation efforts (p. 3). Issues related to the increasing isolation of minority students in the country's large urban areas, the effects of recent immigration, the growing financial burden on school districts to effect integration, the public backlash to the negative effects of desegregation, and the widening achievement gap have all contributed to this trend.

In 1991, the Supreme Court reviewed the Board of Education of Oklahoma v. Dowell case. It found that "formerly segregated school districts could be released from court-ordered busing once they have taken all 'practicable' steps to eliminate the legacy of segregation" and that "school districts are not responsible for remedying local conditions, such as segregated housing patterns" (Weiler, 1998, p. 3).

This "practicable" test was also applied in the 1995 Missouri v. Jenkins case where the Supreme Court ruled "a desegregation plan does not have to continue just because minority student achievement scores remain below the national average," but rather "the state could only be required to do what is practicable for remedying the vestiges of past discrimination" (Weiler, 1998, p. 3-4).

The impact of these court decisions still remains to be seen, however many desegregation advocates believe that this trend portends a return to segregated public schools, especially in the cities. This trend toward resegregation is documented in the research of Gary Orfield and others (Orfield, Bachmeier, James \& Eitle, 1997) where 
they note that "overall, the level of black segregation in U.S. schools is increasing slowly, continuing an historic reversal first apparent in the 1991 enrollment statistics" (p. 7).

Compounding this trend is the rise in minority student population in the U.S. Using comparative data from 1968 to 1994 , "there has been a huge growth (178\%) in the number of Latino students during the 26 years" while "the number of white (Anglo) students declined 9\%" (Orfield et al., 1997, p. 7). In many cases, this rapid shift in demographics has caused tension. Contreras and Stephens (1997) found that in these cases, "an unwholesome separatism is the norm in many schools as the various sociocultural groups sort themselves out and build walls that they consider necessary for their emotional and even physical protection" (p. 189).

According to Orfield et al (1997), "Latino segregation has become substantially more severe than African American segregation" (p. 10) and "the relationship between segregation by race and segregation by poverty in public schools across the nation is exceptionally strong" (p. 11). Other researchers noted that "immigrant students are likely to attend resource-poor, overcrowded, inner-city schools where the costs of adequate educational services come high" (Contreras \& Stephens, 1997, p. 188). This is significant when you understand the strong correlation between "poverty concentrations and low achievement" (Orfield et al., 1997, p. 11). In fact, "high poverty schools have generally lower levels of educational performance and are less likely to prepare students for college than more affluent schools" (Weiler, 1998, p. 4). Thus, it appears that socioeconomic factors substantially contribute to the increased isolation of minority students in today's urban centers. 


\section{Recent Trends in Miami-Dade County}

Similar to national trends, desegregation in Miami-Dade County today reflects the impact of immigration, recent court decisions and public opinion. Each of these trends has contributed to a notable relaxation in desegregation policies.

According to demographic statistics from $2001,56 \%$ of the students enrolled in Miami-Dade County Public Schools are Hispanic, 31\% are Black, $11 \%$ are White and 2\% are reported as Other (Miami-Dade County Public Schools Statistical Highlights, 2001). This rise in the Hispanic population mirrors national trends in other urban areas across the country. Additionally, the decreasing population of White students suggests a "white flight" from the public schools and the local Miami area in general. The result of this trend is a majority minority student population, with compounding socio-economic factors.

Recently, public opinion toward forced busing for desegregation purposes has caused the local school board to relax its use of this method. Using Frank C. Martin as the same example, pressure from both Black and White parents in 1996 caused the school board to reconfigure the school from a kindergarten and sixth grade center school to a traditional neighborhood elementary school. A magnet program was also added to the school to encourage voluntary desegregation in lieu of forced busing.

As in other systems across the country, the courts have also contributed to weakened desegregation controls in Miami-Dade County. In June 2001, the United States District Court released Miami-Dade County from court-supervised desegregation to a position of unitary status (Pate v. School Board of Miami-Dade County, Florida, 2001). In this case, the court found that during its supervision, the local school district 
had maintained unitary status, that provisions were in place to minimize resegregation if supervision by the Court was withdrawn, and that the district had "eliminated the vestiges of segregation to the extent practicable" (Pate v. School Board of Miami-Dade County, Florida, 2001, p. 39). Therefore, as of June 30, 2002, the Court ends its supervision over the district.

While this change in status does not release the county from its obligation to provide an integrated school system, taken in conjunction with the other local trends noted above, this change does imply a "loosening" of the policies and procedures initially developed to ensure desegregation. According to school board attorney, Phyllis Douglas, the result of this decision is that race can no longer be the primary criteria for student and/or staff placement. Therefore, racial ratios governing magnet school participation and controlled staffing are in question.

Future Desegregation Trends

As a rebuttal to the social and cultural failures of desegregation, some are proposing a new "separate but equal" approach to public education in America. This new segregationist movement is focused on the creation of "institutional caring, all-black immersion schools, and a supportive network of African American educators" (Hess, 1998, p. 251).

Others suggest school reform that is targeted at accountability issues and student performance rather than racial integration. Under this model, school districts would provide funds "for reform efforts [to] reach the at-risk students" in order to achieve "parity for the district's Black students with their White peers in the system" (Harris, Russo \& Brown, 1998, p. 52). 
Only the passage of time will reveal the future of school desegregation in America. While much of the past desegregation efforts have had significant positive effects for African-American students, recent trends are calling into question its legitimacy. Therefore, it appears that rather than diminishing over time, the issue of public school desegregation is one that is still controversial and debatable today.

Athletics

As noted in the analysis of the data, the subject of athletics in the Miami-Dade Public Schools and Mr. Braddock's position on the issues related to this subject was largely inferred from the context of the transcripts. While not much time was spent during the interviews discussing athletics, Mr. Braddock's long term support for these programs is well-known and was referenced in many of the secondary interviews. The review of the literature on athletic programs in public schools focuses on the rationale for these programs and the current issues related to this subject.

\section{Historical Context}

The role of public school athletic programs across America continues to be a subject for discussion even in light of significant research supporting its viability. First to be subjected to the consequences of the "back to basics" movement or district budget cuts, physical education programs and interscholastic sports programs are often viewed as non-academic, and therefore relatively unimportant components of the school curriculum. Advocates for these programs point out that "sports participation can help young people appreciate health, exercise, and fitness; learn about themselves and how to handle adversity; and experience teamwork and display sportsmanship" (Rasmussen, 1999-2000, p. 26). Critics suggest that athletics detract from the academic benefits of school. They 
point to research findings that suggest "student athletes' grade point averages are lower than the overall student body" (Jones, 1998. p. 9).

The popularity of athletic programs across America is evident by the statistics. According to data collected by Karen Rasmussen (1999-2000), "approximately 2 million young people in the United States, ages 5 to 17, participate in agency-sponsored sports, such as Little League Baseball. About 14 million participate in recreational sports programs and about 2 million young people play club sports" (p. 27). This data, along with the increasing popularity of both male and female professional sports programs, suggests that athletics should have a viable place in the public school curriculum. Rationale for Athletic Programs in Schools

The role of athletics in schools has received significant attention in recent years. Research on the subject has revealed a range of physical, social, emotional and academic benefits derived from athletic participation, providing support for their continued existence.

The development of a healthy lifestyle is an important benefit of student participation in athletics. As today's society continues to impose high levels of stress on the individual, the health benefits derived from recreational and athletic activities can be significant. According to Seigenthaler (1997), "leisure enhances health because it serves as a buffer to life's stressful events," (p. 24). Further, he found that "students with high levels of participation in a variety of leisure activities experienced higher rates of perceived physical, mental and social health" (Siegenthaler, 1997, p. 25). Therefore, participation in physical education and athletic programs seems to develop important lifelong habits that contribute to better health and well-being. 
In addition to the physical health benefits of sports participation, athletics also provide unique opportunities for learning outside of the traditional classroom setting. Physical education and athletic programs "enable students to master new skills and explore different roles," (Silliker \& Quirk, 1997, p. 288). For many students, physical education class or participation in a particular sport provides a forum for success beyond the academic realm of school. "Sports participation can help young people appreciate health, exercise, and fitness; learn about themselves and how to handle adversity; and experience teamwork and display sportsmanship" (Rasmussen, 1999-2000, p. 26). In addition, the social development aspect of sports cannot be overlooked. According to Elizabeth Bresson (1980), “children need to participate in different social interaction forms that require different social skills in order to fully develop their social potential" ( $p$. 5). Sports and recreation activities provide another context for developing social interaction skills in children.

Many critics of athletic programs in public schools and universities subscribe to the pervasive stereotypes that "student athletes are inferior students" and that "athletics contribute to the academic inferiority of the student athletes" (Jones, 1998, p. 9). However, much of the research data on this subject contradicts these beliefs. In contrast with the stereotypes of the student athlete, research in this area revealed a positive link between athletics and academic performance. According to the work of Zaugg (1998), "athletic participation raised educational aspirations, self-concept, and GPAs" (p. 64). This finding was further supported by a study conducted at UW-Whitewater where Dianne Jones (1998) found that "student athletes had higher overall grade point averages than the general student body" (p. 9) and that "student athletes had higher overall 
graduation rates than those of the overall student body" (p. 10). These results suggest that the qualities needed for success in athletics: hard work; self-discipline; perseverance; determination; concentration; and focus, do transfer into the academic domain (Simons, Van Rheenan \& Covington, 1999).

Further research on student athletes also dispels the myth that college athletes usually select majors that were not considered substantive. In their research, Silliker and Quirk (1997) found that in many cases student athletes had "higher career aspirations" than did the general student population (p. 288). This finding is also supported by Jones' research at UW-Whitewater where student athletes were far more likely to select more challenging fields of study than their non-athletic counterparts (1998). Thus, it appears that student participation in athletics actually enhances academic performance overall, rather than detracting from it.

\section{Other Benefits}

Other benefits have also been cited as deriving from participation in athletic programs. One such result of student participation in athletics is directly linked to the development of leadership skills. Research has found that "students who participate in athletics are exposed to leadership role models (e.g., coaches) and often are required to exercise some degree of leadership with their peers" (Dobosz \& Beaty, 1999, p. 215). Additionally, Zaugg (1998) found that athletic participation "developed personal and moral character while promoting leadership" (p. 64). Thus, "if developing leadership skills is indeed one of the goals of the educational system, and participation in sports fosters the acquisition of such skills, then maintaining athletic programs is strongly recommended," (Dubosz \& Beaty, 1999, p. 219). 
Finally, an often overlooked benefit of school athletics is the creation of social capital. Social capital is defined as "the resources available to actors that result from their interaction within a social network" (Fritch, 1999, p. 2). In his research, Wayne Fritch (1999) found that the "athletic program of the school is a significant mechanism for the formation of social capital in the community" (p. 2) and that "sports related activities provide more opportunities for social capital formation than any other school activity (p. 27). Therefore, if parent participation and community support are desirable contributors to public education, athletic programs can be important vehicles for achieving this goal.

\section{Current Trends in Athletics}

Some of the most significant changes in athletics over the past few decades have been the result of federal guidelines and regulations governing public schools and universities. One such change has been the result of the enactment of Title IX, a bill that requires equal support of male and female sports programs in public institutions.

"The Title IX Education Amendment Act of 1972 prohibits institutions that receive federal funding from discriminating on the basis of gender in educational programs or activities" (Rasmussen, 1999-2000, p. 29). Given the past emphasis on male sports programs, the impact of this bill has been dramatic.

Since its passage in 1972, female participation in sports programs at both the high school and college level has consistently increased. In a longitudinal study of intercollegiate sports, "the average number of teams offered per school is at an all-time high of 8.14. In 1972, the number was a little over 2 per school," (Acosta \& Carpenter, 
2000, p. 2). This increase in participation is also reflected in the recent interest and popularity of competitive female sports programs, such as soccer and basketball.

Contributing to their athletic appeal, research on female student athletes has found them to be highly desirable student recruits. "Female student athletes are superior to male student athletes... in high school GPAs, Scholastic Aptitude Test (SAT) scores, as well as college GPAs" (Simons, Van Rheenen \& Covington, 1999, p. 151). Thus, female athletes have made significant contributions to colleges and universities both on and off the field.

Other major changes in athletic programs across the country have stemmed from federal mandates protecting individuals with disabilities. Under Section 504 of the Rehabilitation Act of 1973, the Americans with Disabilities Act and the Individuals with Disabilities Education Act, the federal government has "extend[ed] school district responsibility and potential liability beyond special education to a wider segment of students and to extracurricular activities" (Sullivan, Lantz \& Zirkel, 2000, p. 258). In practice, this has come to include those state organizations that oversee and govern athletic programs. Recent court decisions have found that "public schools delegate sufficient authority to state athletic associations to render the associations themselves instrumentalities of the state, thus requiring the associations to comply with the requirements made of public entities" (Sullivan, Lantz \& Zirkel, 2000, p. 260). Accordingly, many state athletic associations are now providing recourse for disabled athletes through opportunities for rule waivers based upon individual considerations. 


\section{Athletic Trends in Miami-Dade County}

Reflecting national trends, the athletic programs in Miami-Dade County are subjected to many of the same influences. Due to budget constraints and a six-period school day, the current Pupil Progression Plan only requires elementary student participation in physical education classes and one year of Personal Fitness at the high school level. And while many middle schools encourage participation in physical education classes, it is not mandatory.

Extracurricular athletic programs are primarily supported at the senior high school level, with football being the number one revenue sport. District financial support is limited to coaching supplements, transportation costs, official fees, and some equipment purchases. The Athletic Director position in the high school is only partially subsidized by the district. Any additional needs are dependent upon ticket sales, booster clubs, and fund raising activities.

In recent years, high school athletic programs have been affected by Title IX. In order for schools to provide equal levels of participation for male and female athletes, many male sports have been eliminated. This is largely due to the high number of male athletes participating in football.

While male athletic programs have felt the negative impact of Title IX, female sports are flourishing. Not only are more schools offering a wide range of female sports, but in many instances women athletes have the opportunity to compete on male teams, such as wrestling.

Handicapped students are also benefiting by the changes in federal guidelines. In Miami-Dade County, a comprehensive Disabled Sports Program and support of the 
Special Olympics offer students a wide range of available sports programs. And just as federal and state regulations require student access to the least restrictive environment, many handicapped students can compete with their non-disabled counterparts.

If we believe, like Judy Young executive director of the National Association for Sport and Physical Education, that "within schools, athletics, like all co-curricular programs, 'should support and extend the total education and individual development of kids"' then the role of physical education and athletic programs in public schools should be seen as viable aspects of the total school curriculum (Rasmussen, 1999-2000, p. 27).

From the data, it can be suggested that Mr. Braddock's support of school athletic programs reflected an indepth understanding of many of the same issues presented in this review. Guided by the variables of his perspective, i.e., fairness, honesty, integrity, courage and situational context, Mr. Braddock often expressed his perspective on these issues and was instrumental in promoting many of the changes that are evident in school athletic programs today.

\section{Bilingual Education}

The fourth element of Mr. Braddock's perspective for review is bilingual education. Defined as an educational program "where the non-English language is used for at least fifty percent of the student's instructional day," bilingual education or dual language immersion programs are common in most countries in the world (Saucedo, 1997, p. 3). However, in the Miami-Dade County Public Schools, as in most other areas of the United States, bilingual education programs are limited in scope and limited in number. 


\section{Rationale for Bilingual Education}

Although bilingual education is still considered uncommon in the United States today, it is widely practiced in other countries around the world. In fact, research indicates that "there are many more bilingual or multilingual individuals in the world than there are monolingual" (Tucker, 1999, p. 3). For these students, "bilingualism or multilingualism and innovative approaches to education that involve the use of two or more languages constitute the normal everyday experience" (Tucker, 1999, p. 3).

Proponents of bilingual education point to a variety of reasons for the establishment of dual language programs in public schools across America. One of the most profound reasons for the establishment of these programs is related to our increasing reliance on each other in today's global economy. For purely economic reasons, "a multilingual workforce enhances America's economic competitiveness abroad" (Marcos \& Peyton, 2000, p. 3). Bilingual education can offer "secondary students access to continued development of language skills and cultural knowledge that, in an increasingly global economy, will be marketable assets" as a means of ensuring our continued economic competitiveness (Montone \& Loeb, 2000, p. 8).

In parts of the United States, such as Miami, where there is a large non-English speaking community and where international trade represents a significant contributor to the local economy, the ability to interact in two languages is a definite benefit for the individual. According to Tucker (1999), "cognitive, social, personal, and economic benefits accrue to the individual who has an opportunity to develop a high degree of bilingual proficiency when compared with a monolingual counterpart" (p. 4). In addition, bilingual education also addresses the issue of appropriate instruction for non- 
native English speaking students. In schools where English is taught in conjunction with a student's home language, "language skills and cultural perspectives are added without progressively destroying the child's home language and culture" (Goodman, 1972, p. 5). In this model, both English speaking and non-native English speakers benefit from an approach that "promotes tolerance and intercultural awareness" (Marcos \& Peyton, 2000, p. 3). Further, bilingual education also ensures a "lower likelihood of tracking and other practices that might be detrimental to language minority students" thereby providing nonnative English speakers with broader access to a wide range of educational opportunities (Montone \& Loeb, 2000, p. 9).

Academically, "research has found a positive link between second language proficiency and cognitive and academic ability" (Marcos \& Peyton, 2000, p. 3). Some of the explanations for this increased academic ability are related directly to language acquisition. According to Bialystok (1999), "bilingual children routinely pay attention to abstract dimensions of language that are essentially transparent to monolingual children" thereby enhancing their overall cognitive abilities (p. 637). Additional research has supported this finding and further suggests that "individuals who learn a second language are more creative and better at solving complex problems than those who do not" (Marcos \& Peyton, 2000, p. 3). In light of the high value that our society places on creativity and innovation in the workplace, it would seem that bilingual education has a viable place in our public school curriculum.

\section{Current Trends in Local Bilingual Education Initiatives}

Presently, bilingual education initiatives in Miami-Dade County are limited. Although all secondary schools and most elementary schools offer a foreign language 
program (usually Spanish), most students do not have access to a comprehensive language program. The exception to this would be found in isolated school programs such as the International Studies Program at Sunset Elementary, Carver Middle School and Coral Reef High School. With these few exceptions, the traditional foreign language programs found in most schools are usually not very successful in developing fluency and/or proficiency in the language.

Recently, as part of the Governor's One Community, One Goal initiative, bilingual education has gained new support in Miami-Dade County. Based on demographic statistics from 2000 , the current population of the county has risen to a majority Hispanic representation of $57 \%$, with only $21 \%$ of the population reported as white, non-Hispanic and 19\% Black (U.S. Census 2000). Enrollment in the Miami-Dade County Public Schools for the same year reflects a population where $56 \%$ of the students are Hispanic, 31\% Black, 11\% White and 2\% Other (Miami-Dade County Public Schools Statistical Highlights, 2001). Of these students, $51 \%$ of students speak Spanish as home language, compared to only $9 \%$ of the non-Spanish speaking secondary school students enrolled in Spanish FL (Miami-Dade County Public Schools Statistical Highlights, 2001). These statistics, combined with the Governor's report that $70 \%$ of all exports from Miami-Dade County are sent to Central and South America, empirically suggest the need for a bilingual work force. In response to this need, Mayor Alex Penelas launched his One Community One Goal initiative in 1997. Broadly stated, his vision for future economic development in Miami was dependent upon "the collaboration between businesses and educators" as a means of developing a "technically trained" local 
workforce skilled in nine industry focus areas (One Community One Goal Blueprint, 1997).

The role of public education as means of promoting the One Community, One Goal initiative is clearly apparent. Objective \#2, Strategy \#5 of the plan suggests the need for bilingual education in order to "ensure that a substantial portion of Greater Miami's workforce is literate on a professional/technical level in English and at least one other language" (One Community One Goal Blueprint, 1997, p. 67). Objective \#4, Strategy \#2 suggests that the local school board "emphasize the need for proficiency/literacy in foreign languages" in order to develop this bilingual workforce (One Community One Goal Blueprint, 1997, p. 71).

To date, no major dual language programs have been proposed by the MiamiDade County School Board as a response to the mayor's initiative, however, the rationale for these programs has clearly been established. For the present, access to a bilingual education is reserved for non-native English speakers and for participants in only a handful of dual language programs previously established in the district.

From this review of the literature on bilingual education programs, $\mathrm{Mr}$. Braddock's commitment to this initiative is supported by research demonstrating gains in academic achievement and economic benefits as well. Although initially unsuccessful, the impetus for a bilingual education Miami-Dade County is again being revisited.

Comprehensive Leadership Role

Unlike the other elements previously discussed, the element identified as Mr. Braddock's comprehensive leadership role was not characterized as a significant issue for educational policy making. Rather, Mr. Braddock's comprehensive leadership role was 
identified as an element that holistically characterized his career as a school board member and was influenced by the variables of his perspective. While a comprehensive review of the literature on leadership and leadership theories would far exceed the parameters of this study, the following discussion is focused on leadership as it relates to those variables identified in Mr. Braddock's perspective on his career.

\section{Leadership Defined}

The study of leaders and the development of leadership theories encompasses a historical timeframe as old as humankind itself. From ancient mythology to the Bible to contemporary historical figures, "the study of history has been the study of leaders - what they did and why they did it" (Bass \& Stodgill, 1990, p. 3). Defining leadership is often as elusive as identifying a definitive theory to describe leadership. According to Webster, a leader is "someone who acts as a guide" and leadership is "the act of leading" (Webster's New Collegiate Dictionary, 1976). In a similar vein, Dubosz and Beaty (1999) define leadership as the "capacity to guide others in the achievement of a common goal" (p. 215). For Peter Senge (1996), leaders are people who "walk ahead," and are "genuinely committed to deep change in themselves and in their organization" (p. 45). Using this definition, Hodgkinson (1991) views leadership as an individual's commitment to a particular institution's value or purpose. And defined in the context of the organization, "leadership is essentially building and maintaining a sense of vision, culture, and interpersonal relationships" (Day, 2000, p. 57).

For this discussion, leadership can be defined in all of these ways including the following definition. According to Bass and Stodgill (1990), leadership is "the focus of group processes, as a matter of personality, as a matter of inducing compliance, as the 
exercise of influence, as particular behaviors, as a form of persuasion, as a power relation, as an instrument to achieve goals, as an effect of interaction, as a differentiated role, as initiation of structure, and as many combinations of these definitions" (p. 11). This comprehensive definition provides a general foundation for this review.

\section{Leadership Theories}

Just as there are a myriad of definitions for leadership, there are a multitude of theories related to leadership. However, for this review, three particular leadership theories: trait theory, situational leadership theory and transactional vs. transformation leadership theory seem pertinent.

Trait theory. Beginning in the 1920's, a concept of leadership that focused on the attributes of the leader himself became known as Trait Theory. Early models of this theory posited that there were distinct personal characteristics that only leaders possessed. And while this theory was later discarded for more comprehensive explanations, it was revisited in later years.

With the benefit of better research methods and a more comprehensive theoretical framework, Trait Theory was re-examined in the 1970's. The results of this research did reaffirm the original findings that certain personal attributes or traits were positive contributors to effective leadership. From these studies, "personal integrity...independence, objectivity ... and persistence against obstacles" were all found to be attributes of successful leaders (Bass \& Stodgill, 1990, p. 88).

With this theoretical foundation re-established, further research on educational leadership theories was conducted. In a leadership study of principals in the United Kingdom, Day (2000) found that these leaders' "core personal values were care, equity, 
high expectations and achievement" (p. 56). Kouzes and Posner (1995) found that leaders were almost always, "honest, forward-looking, inspiring, competent" (p. 102).

Personal integrity and the strength of one's own convictions were also found to be significant factors in Judith Bardwick's research. She found that effective leadership was almost always reliant upon trust and that "without integrity, trust is never achieved" (Bardwick, 1996, p. 137). Additionally, she demonstrated another interrelationship between integrity and courage. "Having integrity, I think, rests partly on personal courage" (Bardwick, 1996, p. 137). This definition of integrity as stemming from personal courage was reinforced in the Day study. He revealed that "it is important that the head [principal] can demonstrate integrity in the face of adversity" as a means of signifying leadership (Day, 2000, p. 58).

For Charles Handy (1996), the leader of the future "requires great strength of character" in order to effect positive change (p. 9). And in his reflections on Leading a Diverse Work Force, John Work (1996) stated that leadership "requires individuals to take considerable risks and to do things that others are not willing to do" (p. 76). Thus, it appears that while Trait Theories do not expound on any other concept of leadership beyond the individual leader himself, certain attributes that contribute to successful leadership are reflected in contemporary literature on the subject.

Situational leadership theory. As discussed in the presentation and analysis of the data, situational context was a significant external variable in Mr. Braddock's perspective on his career. Whether it contributed to or impeded his effectiveness, the interaction of Mr. Braddock's personality and personal values in any given situation contributed to the 
outcome. Therefore, a review of Situational Leadership Theory seems appropriate in order to understand this relationship.

Initially, Situational Leadership Theories arose in response to Trait Leadership Theories. Generally, Situational Leadership Theory posits that "leadership is all a matter of situational demands, that is, situational factors determine who will emerge as leader" (Bass \& Stodgill, 1990, p. 38). As such, leadership arises from the context of the situation: the interaction between leader, subordinates and environment.

Under this umbrella of situational leadership, numerous other theories have arisen as attempts for further explanation of these interactions. House's Path-Goal Theory explained leadership in terms of the individual's ability to assess the task, the ability and motivation of the worker, and the work environment. Fiedler's Contingency Theory viewed leadership as the result of the situational context and the leadership style preferred by the leader. Blake and Mouton created a grid that emulated a behavioral approach for effective leadership by adopting a particular style to meet the needs of the situation. The Hersey-Blanchard Situational Leadership Model was another attempt to prescribe leadership interactions with subordinates in the organization. (Bass \& Stodgill, 1990).

These theories are supported by contemporary research in sociology that reflects the importance of situation in determining an individual's fate. According to C. Wright Mills (1959), individuals understand themselves by first understanding the period in which they live. Thus, the context of the situation does much to define the experience of an individual. 
According to Joseph Garcia (1981), emerging views of leadership reflect a situational approach with "a concern to include extra-organizational variables - the relationship of the leader to the larger social structure and environment of which the organization is a part" (p. 31). Alfred DeCrane, Jr. (1996) exhorts today's leaders to "seize the opportunities of the present without compromising the need to invest and build for the future" demonstrating the need for an awareness of the present situation as well as the future (p. 253). This seems particularly relevant in today's rapidly changing workplace. Likewise, Farren and Kaye (1996) suggest that effective leadership today requires "a panoramic view of the present [to] encompass all the factors we need to consider to anticipate change and plan effectively for the future" (p. 181). Applying these theories, successful leaders understand the contributing factors of external forces and are able to tailor their actions and decisions to meet the needs of the situation.

Transactional leadership versus transformational leadership. A final leadership theory that seems pertinent to this study is related to Transactional Leadership versus Transformational Leadership. As defined by Bass and Stodgill (1990), "the transactional leader works within the framework of the self-interests of his or her constituency, whereas the transformational leader moves to change the framework" (p. 23). "Transformational leaders were categorized as intellectuals, leaders of reform or revolution, and heroes or idealogues" who "ask followers to transcend their own selfinterests for the good of the group, organization, or society," whereas transactional leaders were defined as "opinion leaders, bargainers or bureaucrats, party leaders, legislative leaders, and executive leaders" (Bass \& Stodgill, 1990, p. 23). 
In his research on heads of schools in Britain, Christopher Day (2000) redefines transactional and transformational leadership in other terms. In his study, transactional leadership could be equated with management, where the head of school focused on "coordinating, supporting, and monitoring organizational activities" (Day, 2000, p. 57). In contrast, transformational leadership was "essentially building and maintaining a sense of vision, culture, and interpersonal relationships" (Day, 2000, p. 57). In this manner, transformational leadership emphasized a sense of vision and the ability to achieve this vision through interpersonal relationships. Therefore, Mr. Braddock's comprehensive leadership role during his thirty-eight year tenure can be viewed from a variety of leadership theories.

\section{Summary of the Chapter}

The purpose of this study was to describe and explain Mr. Braddock's perspective on his school board career. Through indepth interviews and secondary sources, five elements of his perspective, i.e., teacher professionalization, desegregation, athletics, bilingual education, and his comprehensive leadership role, and five variables of his perspective, i.e., fairness, honesty, integrity, courage, and situational context, were identified.

In Chapter II, a review of the literature pertaining to each of the five elements of his perspective and encompassing the five variables of his perspective was presented in a holistic manner. For each of the four elements that were related to specific educational issues, i.e., teacher professionalization, desegregation, athletics, and bilingual education, the review of the literature provided an historical perspective of the issue along with a discussion of current trends both nationally and locally in Miami-Dade County. The fifth 
element of Mr. Braddock's perspective, his comprehensive leadership role, was discussed in the context of leadership theories. In this manner, each of the previous four elements and each of the five variables of his perspective could be viewed as contributors to his comprehensive leadership role. 


\section{CHAPTER III}

\section{METHODOLOGY}

When dealing with the complex and often unpredictable behavior of people and organizations, Berg (1998) finds that qualitative research methods are often more able to reveal "the various social contours and processes human beings use to create and maintain their social realities" (p. 7). Further, as a method of qualitative research, the use of life or oral histories enables the researcher to "uncover the unknown; to answer questions; to seek implications or relationships of events from the past and their connections with the present; to assess past activities and accomplishments of individuals, agencies, or institutions; and to aid generally in our understanding of human culture," (Berg, 1998, p. 200).

Yow (1994) defines oral history as "a specific research method within the general designation of qualitative methodology," where "the understanding of the multiplicity of experiences in a total life context is the objective" (p. 8). According to Atkinson (1998), "an oral history most often focuses on a specific aspect of a person's life, such as work life or a special role in some part of the life of a community" (p. 8).

Through the in-depth recorded interview, the researcher is able to probe behind the public-oriented statement, examine the motives behind particular actions, obtain the viewpoints of people from all socioeconomic backgrounds, understand the daily lives of others, reveal the meanings of artifacts, symbols, and images, and explore various dimensions within communities (Atkinson, 1998; Dunaway \& Baum, 1996; Yow, 1994).

Given that the intent of this study was to compile an oral history in order to describe and explain Mr. Braddock's perspective on his thirty-eight year career as a 
member of the Miami-Dade County School Board, it was necessary to utilize a method that allowed insights into his unique experiences and perspective. Thus, the recorded indepth interview, or oral history method, was selected as the primary research instrument for this study.

\section{Preparation}

As in any research project, forethought and planning were critical components of a successful oral history interview. Having selected the primary method for data collection and obtained permission from $\mathrm{Mr}$. Braddock to conduct the study, it was important to prepare for the interviewing stage of the project. As Yow (1994) suggests, creating an interview guide can help to delineate the scope of the study and will later serve as a helpful tool during the interview process. Further, attention to question sequencing and structure ensures responses are both extensive and revealing (Berg, 1998; Janesick, 1998; Yow, 1994). The completed interview guide contained the initial topics for discussion, but did not limit the interviews to only these topics (see Appendix 2).

A consent form was signed by Mr. Braddock (see Appendix 3) and an affirmation of intent form (see Appendix 4) was signed by the researcher to ensure ethical responsibility and reporting in the study.

\section{Description of the Participants}

\section{G. Holmes Braddock}

A member of the school board since 1962, G. Holmes Braddock was first elected to serve at the age of 37 . Now retired at age $76, \mathrm{Mr}$. Braddock was a constant influence on local school board policy-making for 38 years. During his tenure on the board, he served as chair seven times and vice-chair six times. 
Mr. Braddock's influence as a school board member was not limited to the local Miami-Dade community. He also served in various leadership capacities at both the state and national level. He held every office, including president, for the Florida School Boards Association and the Council of Great City Schools. He served as chairman of CUBE (Council of Urban Boards of Education) and a member of the CUBE Steering Committee, and was elected to two consecutive terms to the National School Boards Association's Board of Directors. He was recognized on numerous occasions by these organizations for his contributions to public education (See Appendix 1).

Secondary interview sources were sought as a means of validating $\mathrm{Mr}$. Braddock's perspective. With the exception of one, Dr. Wayne Blanton, these secondary sources were all former "influentials" in the Miami-Dade Public School system who had worked closely with Mr. Braddock during his tenure. Dr. Wayne Blanton was selected in order to provide a valid perspective on Mr. Braddock's state and national leadership. Each of these secondary sources is briefly introduced below.

Dr. Wayne Blanton

Dr. Wayne Blanton is the Executive Director of the Florida School Boards Association, a position that he has held since 1985. In his role with FSBA, Dr. Blanton worked very closely with Mr. Braddock on many state and national initiatives.

Dr. Joseph Fernandez

Dr. Joseph Fernandez served as the superintendent of the Miami-Dade County Public Schools from July 1986 to December 1989, before leaving to accept the position of Chancellor for the School Board of the City of New York. Presently, Dr. Fernandez is retired and lives in Florida. 
Janet McAliley

Mrs. Janet McAliley served as a member of the Miami-Dade County Public School Board from 1980 until 1996. During her tenure, she was an advocate for the rights of minorities and a comprehensive educational program that provided health services for needy schoolchildren.

Alan Olkes

Mr. Alan Olkes served as interim superintendent of the Miami-Dade County Public Schools in 1997 following the resignation of then superintendent, Octavio Visiedo. A long-time school system administrator, Mr. Olkes is now retired from the school system and is co-founder of Chancellor Academies.

\section{Pat Tornillo}

Mr. Pat Tornillo has served as the Executive Director of the United Teachers of Dade for thirty-nine years. With similar years of career service, Mr. Tornillo and Mr. Braddock have shared a long-term working relationship.

Octavio Visiedo

Mr. Octavio Visiedo was superintendent of the Miami-Dade County Public Schools from 1990 to 1997. After retiring from the school system in 1997, Mr. Visiedo co-founded the educational consulting firm, Chancellor Academies.

Because of their professional knowledge of public school education and their working relationship with Mr. Braddock, each of these participants was able to contribute observations that were both insightful and relevant to this study. 


\section{Data Collection}

A successful pilot study with Mr. Braddock completed in the spring of 1998 served as a basis for developing a plan for data collection. Interviews with Mr. Braddock began in September 1998 and were conducted at his residence in the evenings. Each interview was limited to two hours in duration. Time in between interviews provided opportunities for reflection and synthesis.

Initial interview questions were derived from the interview guide. However, as new themes or topics were introduced by the narrator, additional questions were developed (Marshall \& Rossman, 1995). Further, in acknowledgement of his collaborative role in the research process, Mr. Braddock was offered the opportunity to suggest topics of his own to discuss (Atkinson, 1998; Dunaway \& Baum, 1996; Janesick, 1998; Yow, 1994). Each of the interviews was tape-recorded for future transciption and one follow-up session was scheduled with Mr. Braddock for the purpose of reviewing newspaper clippings, photographs, and other memorabilia.

Because the intent of an oral history is to "hear" the narrator through the text, each tape was completely transcribed (Atkinson, 1998; Baum, 1977; Joyner,1996; Marshall \& Rossman, 1995; Yow, 1994). And because the best person to do the transcription is the interviewer, the researcher transcribed the tapes using a dictaphone and computer (Baum, 1977). In accordance with information from Baum and Yow, this process took approximately six to ten hours per every hour of tape.

Editing of the transcripts was limited to the deletion of "crutch" words and phrases that were repeated over and over, and the addition of stage directions or other 
information needed for clarity and/or fluency (Baum, 1977; Yow, 1994). Additionally, a thorough audit of each tape ensured accuracy in both content and presentation.

Finally, because "the prevailing practice is to persuade the oral author to verify the text for clarity and accuracy," the transcript was returned to the narrator for corrections, whereby the edited transcript then became "the true end product" (Starr, 1996, p. 42).

While the tape-recorded and transcribed interviews provided the primary source material for this investigation, significant events presented in the history were corroborated by official records, written accounts, or interviews with others who were also present at the time (Marshall \& Rossman, 1995). Secondary sources such as media accounts, evidence from Mr. Braddock's personal effects, and interviews with others who knew Mr. Braddock, served as potential secondary resources for establishing the validity of the narration.

Additionally, two non-participant observations were conducted at a monthly school board meeting with the intent of observing Mr. Braddock in his official role as school board member (Dunaway \& Baum, 1996; Janesick, 1998). Perceptions gained from the interactions in this formal arena provided valuable insights into Mr. Braddock's public image (Mintz, 1996; Scribner \& Layton, 1995)

\section{Data Analysis}

Because "meaning is constructed in the ongoing social relationship between the researcher and the participants in the study" (Janesick, 1998, p. 62), data analysis in qualitative research occurs at all times during the process. However, once the data collection process was completed, formal analysis and interpretation of the data began. 
In accordance with Janesick (1998), it was anticipated that the time spent in analysis would equal that of the time spent in the field. Initial analysis focused on the validity and reliability of the narration. Hoffman (1996) states that in qualitative research, validity and reliability refer to the conformity between the narration and other official records, and the internal consistency of the narration. However, Atkinson (1998) asserts that "reliability and validity are not necessarily the appropriate valuative standards... [since] historical truth is not the main issue in narrative. What matters most, perhaps, is that the life story be deemed trustworthy, more than true" (p. 59-60). Therefore, "the narrative approach to the study of lives maintains emphasis on internal coherence as experience by the person, rather than external criteria of truth or validity" (Atkinson, 1998, p. 61). This was an important distinction to be noted and applied during analysis.

In addition to verifying the "facts" in the narrative, the analysis of data focused on the "meaning" of the data (Kvale, 1996). Guided by the exploratory questions and interpretative methods proposed by Steiner Kvale (1996), data analysis was "ad hoc" (p. 193) allowing for a wide range of open interpretation. Because of the inherent nature of the data collected, it was expected that most of the analysis would focus on meaning condensation. In this method, the data was viewed both holistically and systemically in order to discover "natural meaning units" (Kvale, 1996, p. 194). This analysis provided a thematic approach for interpreting the text and answering the exploratory questions.

Additionally, because the data was presented in a narrative form, it seemed appropriate to utilize a second method of analysis, i.e. meaning structuring through narratives. Here, the data was viewed "as leading to a story the researcher wants to 
tell...providing new convincing insights and opening new vistas for understanding the phenomena investigated" (Kvale, 1996, p. 201).

Finally, as in any ad hoc analysis, the opportunity to apply additional analysis methods to the data existed. It was impossible to fully predict the depth and breadth of the interview topics and therefore impossible to fully anticipate the total scope of the analysis. However, whatever the analysis method, the emphasis was to arrive at interpretations that are founded on theory, as well as those that might be derived from subjective experience (Atkinson, 1996).

\section{Presentation of the Data}

The very essence of oral history are "the words of the person telling the story" (Atkinson, 1998, p. 2). Therefore, it was the researcher's intent to present the data entirely in a first-person narrative (Atkinson, 1998; Baum, 1977; Dunaway \& Baum, 1996; Yow, 1994). Additionally, in order to present the analysis clearly, an organizational framework was developed to depict the results of the study (Janesick, 1998). From this framework, "the connections, meanings, and patterns that exist in the story itself" (Atkinson, 1998, p. 64) were elucidated for the reader with excerpts from the narrative text to support the findings (Kvale, 1996).

The Role of the Researcher

According to Janesick (1998), "the researcher is not passive. Prospective researchers must begin to be able to recognize their own investment in the research project and how critical the definition of their role in the project remains" (p. 47). Thus, before an indepth analysis of the interviews could be conducted, it was first necessary to examine my own motives, biases and role in this project. 
A thorough examination of my role as researcher in this project began with an inquiry into the reasons for selecting this topic of study. My own personal interest in oral history began in the classroom during the late 1980's where I had the opportunity to write a grant (which was funded) for a classroom project that involved 75 seventh graders in an investigation into the local history of Miami. The success of this initial project led to the replication of the activity during subsequent years and the compilation of many fascinating life histories. Further, I had the opportunity to present the project to colleagues at the 1993 Fall Convention for the National Council of Teachers of English. All of these experiences contributed to my continued interest in preserving aspects of our local history.

Beyond my personal interest in oral history, my motivation to select $\mathrm{Mr}$. Braddock as a subject for this interview was related to my work within the Miami-Dade Public Schools system. As an administrator in the system, I was extremely aware of the role that politics play in virtually all decision-making. From the local school site, to the district offices, to the school board, interest groups and coalitions, alliances and allegiances all influence what goes on in schools each day.

The school board resides at the strategic apex of this system and presents a public display of politics at work. Since the change to single member district elections, the board had been in a state of flux and transition. Board members now represent a particular constituency, and agenda items have begun to reflect this parochial interest. The resulting policies have had an impact on all of the various stakeholders in the public school system. 
Thus, my professional career and my doctoral coursework in Educational Administration contributed to my general interest in the political aspects of educational leadership and decision-making. And who better to talk about this process but Mr. G. Holmes Braddock, a senior, seasoned, thirty-eight year member of the Miami-Dade County School Board.

As a school board employee, I was also conscious of the professional risk involved in this project. The possibility of revealing subject matter that was both harmful and hurtful to Mr. Braddock, or any of his associates, was one that concerned me. Further, I had to admit my own great respect and admiration for Mr. Braddock, and acknowledge this bias as I entered into the project.

With the acknowledgement of these influences on my role as a researcher in this project, I attempted to ensure a valid perspective by examining the data from various viewpoints. Additionally, I remained cognizant of my ethical responsibilities as a researcher and presented the data to the best of my ability as it appeared in the interviews.

\section{Summary of the Chapter}

Having outlined the rationale for this research in Chapter I and provided a theoretical foundation in Chapter II, this chapter focused on the research methodology of the study. Chapter III discussed the reasons for selecting a qualitative methodology, i.e., the indepth interview or oral history, and the methods by which the research was conducted. Additionally, an explanation of the qualitative process for the presentation of the data and the corresponding analysis was provided. Finally, an acknowledgement of the role of the researcher as an instrument in the research process was discussed. 


\section{CHAPTER IV}

\section{RESULTS}

The purpose of this study was to describe and explain Mr. Braddock's perspective on his career as a member of the Miami-Dade County School Board. Two key exploratory questions guided the study and provided the focus for the presentation and analysis of the data. These questions were:

1. What elements constituted Mr. Braddock's perspective?

2. What variables influenced Mr. Braddock's perspective?

This chapter presents in-depth narrative data from interviews with Mr. Braddock conducted over a period of two years. In addition, secondary interviews were conducted with other educational "influentials" from both the local and state levels who had close working relationships with Mr. Braddock during his board tenure. A description of each of the interview participants was included in Chapter III.

In the analysis of data, an organizational framework was developed to guide the discussion of the exploratory questions. Data from secondary interviews, media sources and Mr. Braddock's own personal effects related to his school board service were included to verify and corroborate Mr. Braddock's perspective. In this way, triangulation of the data was also achieved.

\section{Findings}

A comprehensive review of the taped interviews with Mr. Braddock identified several events and policy issues that were significant during his tenure on the board. These major themes were identified as the elements of his perspective. Further analysis of the transcript data revealed other themes that were related to the underlying beliefs or 
values that permeated the entire text of our interviews and were the basis for Mr.

Braddock's board actions and decision-making. These beliefs or values were identified as the variables of his perspective.

Organizational Framework for Analysis

In order to provide a context for the presentation and analysis of the data, an organizational framework that identified the elements and variables of Mr. Braddock's perspective on his career was developed.

Five key elements of Mr. Braddock's perspective were identified in the data. From these five elements, four constituted significant policy issues for Mr. Braddock:

1. teacher professionalization

2. desegregation

3. bilingual education

4. athletics

A fifth major element of Mr. Braddock's perspective was identified as his comprehensive leadership role. This element was unique in that it was not related to a particular policy issue, but was significant in a holistic analysis of Mr. Braddock's career. Together, these five elements constituted the major themes of Mr. Braddock's perspective.

Further analysis of the transcript data revealed other themes that were identified as the variables of Mr. Braddock's perspective. Four of these variables influenced Mr. Braddock's decision-making and policy position on school board issues and reflected his own personal value system consisting of: 

1. fairness
2. integrity
3. courage
4. honesty

In addition, the data also indicated that one external variable had a significant influence on Mr. Braddock's career as well. The situational context often impacted his ability to influence policy on the school board and was therefore relevant to his perspective. These five variables were some of the factors that were reflected in the elements of Mr. Braddock's perspective.

Transcript data from secondary sources, media print sources, and Mr. Braddock's own personal effects related to his school board service were interwoven throughout the analysis in order to corroborate his perspective and ascertain its internal consistency and trustworthiness.

\section{The Elements of Mr. Braddock's Perspective}

As noted above, five major elements of $\mathrm{Mr}$. Braddock's perspective were identified in the data. In this analysis, each has been presented separately, with secondary source data provided to validate the reliability of $\mathrm{Mr}$. Braddock's perspective. Teacher Professionalization

Chronologically, contemporary issues related to teacher professionalization began to arise during the mid to late sixties and into the early seventies. For Mr. Braddock, these issues were relevant on a both personal and professional level and were the first in which he distinguished himself as an influential leader on the School Board. 
He recalled his first campaign for election to the School Board:

There was no teacher's union then... But there was a CTA. A Classroom Teacher's Association, which was the FEA and the NEA affiliate. And so I ran very strongly on a teacher's platform... I'm a schoolteacher's son. My mama taught for 41 years, so I grew up as a schoolteacher's son... In fact, I had an aunt who taught 44 years.

From his words, it seems apparent that his family's background clearly influenced his own attitude towards the teaching profession.

Collective bargaining. Once elected to the school board, Mr. Braddock worked to promote the professionalization of teachers through collective bargaining and the teachers' union. He articulated a need for fair salary negotiations and the need for other benefits:

I've tried to champion the cause of the labor union. I've been, I was probably the strongest over a long period of time, on teacher benefits and teacher salaries and so forth... In fact when I came on the board we didn't have collective bargaining... The board would in its own session, in its budget session would say, All right, here is where we're going to start teachers this year. $\mathrm{X}$ number. And they would do this. There was never any argument from anybody. The CTA would come down and make a presentation to the board, but it didn't mean anything. The board had already set it... Basically, no benefits other than the teacher retirement plan. When I came on the board there were no health benefits paid for by the board. Nothing... It was always one-sided. Unilateral... I think back then a teacher's salary-a beginning salary-was $\$ 4500$, I think.

Recognizing the clear need for a more professional attitude toward teachers, Mr.

Braddock continued to publicly champion the cause of the labor unions in order to provide better salaries. During this time, he was often quoted in the local papers, as for example, "Money for adequate teachers' pay has to come first in collective bargaining," (Miami News, 1973).

From his perspective, Mr. Braddock saw his own election to the School Board as part of the impetus that changed the Board's attitude toward employees: 
What my coming on the board did - the board had been four to three against even talking to the teachers or employees... There was never any argument from anybody... So when I came on, I beat a very conservative. So then it switch four to three. With that four to three switch, that changed the attitude of the board on how we dealt with employees.

His stance on the professionalization of teaching earned him credibility and wide support from the local community. Executive Director of the United Teachers of Dade, Pat Tornillo, also acknowledged Mr. Braddock's support of collective bargaining as being an important element in his tenure on the Board:

Holmes recognized, and it was one of the areas which was not very popular at that time, that he supported teacher unions and supported our ability to stand up and represent teachers and other school employees. And so, therefore he was a strong supporter of the collective bargaining and the passage of the collective bargaining law in Florida. And he and I built up a very good, I think, relationship. Because Holmes cared about how employees were treated and understood that in ordereven though he was a school board member-in order for employees to be represented and their interests taken care of, they would have to do it through unions. And that was another one of his controversial positions on things which was not always supported by other members on the school board or supported by people in the community... And so he understood that and he believed in it and he lived it.

In these comments, Mr. Tornillo acknowledges both Mr. Braddock's support of teachers and his often controversial role on the board.

Beyond issues of collective bargaining, Mr. Tornillo also noted Mr. Braddock's strong support of teacher professionalization in the classroom:

He has been a consistent supporter of academic freedom and he's been a consistent supporter of teachers and giving teachers the flexibility to be able to teach... Holmes as a school board member spoke up for the rights of teachers... And did that quite forcefully with regard to other members of the school board.

The salience of this particular issue was reinforced by others throughout the study. Former superintendent, Octavio Visiedo, also acknowledged Mr. Braddock's 
strong support of teachers' right to collective bargaining in spite of the fact that it was not a popular issue:

And he was very supportive of the collective bargaining law which was not a popular issue either, but he really believed that the teachers needed that. So he was a major force in that.

Both Mr. Visiedo's comments and those expressed by Mr. Braddock himself demonstrated Mr. Braddock's apolitical approach to dealing with board issues.

Throughout his board tenure, Mr. Braddock was often noted for taking an unpopular stand on important issues.

Teacher walkout. During our interviews, Mr. Braddock discussed the teacher walkout in 1968 at great length. Although not the chair of the school board at the time of the strike, Mr. Braddock's recollections illustrated the significant role that he played in its resolution.

And during the teacher's walkout in 1968, Jack Gordon and I did a lot of the negotiating on the teacher walkout behind the scenes... C.T. commissioned or authorized I should say, Jack and me to deal with the union. So Jack and I would meet with them at night. Late at night. One or two o'clock in the morning. Because they, the union had been at the hotel suite in the Dupont Plaza. Tornillo and Janet Dean and Joe Whelpton were there. So Jack and I would go down there at twelve thirty, one o'clock in the morning when no one was there to see us go in, so to speak. And we'd sit there and try to negotiate our way out of it. Of course, there was not an easy way for them to get out of it. And we had to work it so they could get out of the thing. You know sometimes you get yourself backed into a corner and there's no opening... Tornillo knew it. And I'm not sure how much he would admit to because he backed himself out there into a corner and he had teachers who were out for three weeks and they weren't making that much money. They couldn't afford to stay out. And daily teachers were going back in because they said they didn't have the resources to stay out. But the Florida law then was that if the teacher resigned you were not eligible for rehire for a year. And see all these teachers had turned in resignations. They had signed resignation forms... Tornillo also knew that if you turned them in, that they couldn't get hired again for a year. Well, that would kill us and him. He had 5600 people with him when they went out. You had 5600 teachers without jobs who by law couldn't be rehired. Man, he'd have a disaster on his hands! But the school system would 
have hell! We couldn't open schools. We had some scabs and all kinds of people in there teaching, but we couldn't run a viable school system.

As the story of the teachers' strike continued, Mr. Braddock revealed the ingenious solution to the strike that was derived through negotiations with $\mathrm{Mr}$. Tornillo and district administrators:

So, the trouble is we had to force Pat's hand to turn in the resignations because the public was getting on our case to force him to turn them in... Finally, we negotiated with Pat. We knew that we were going to Tallahassee. So we negotiated with Pat that he would turn them in while we were in Tallahassee. And we would leave word back and Howard McMillan knew about it. He was Ed's alter-ego... He was going to tell the press that, I'm not authorized to take them. I'm not the board. I'm not the superintendent. So, you can turn them in, but I can't accept them. I don't have the authority to accept them, see. So that bought us some more time. So Tornillo came down with boxes and box loads of resignations. But Howard McMillan is out in front of the school board with television cameras said, I'm sorry. If you'd had turned them in yesterday, you could have. I'm not authorized to take them. I'm not the board chair. I can't take them. I'm not the superintendent. I'm not authorized to take the resignations, see. So we had the resignations, and yet we didn't, see. That was the way to try and get us out and get Pat out of this mess, see. In the meantime, we went to Tallahassee to negotiate with the governor, who was a horse's ass. It was Claude Kirk... And finally came out of there with a commitment that would get teachers back to work. And we didn't have to accept those resignations. One thing. We know this, the teachers weren't aware that if they signed those resignations they wouldn't be eligible for a year. They'd never have signed them. They weren't told that. And we didn't tell the public that, see. We just saw that as inflaming things. Fanning the flames over the thing.

Although, Mr. Tornillo did not expound on the particulars of the strike negotiations, he did substantiate Mr. Braddock's recollection and perspective on the teachers' strike:

Holmes did, I would say, support the teachers' strike. And he did help negotiate with Dr. Whigham that we would not take any punitive action against teachers who went out on strike in Dade County. And that we would take them all back and that we would also go beyond that and hire if we needed more teachers, we would hire them from other parts of the state. Holmes took a very strong, positive role in helping to resolve the teachers' strike. 
Finally, Mr. Braddock recalled a comment made by former superintendent, Dr.

Edward Whigham that seemed to summarize his perspective on the teachers' strike:

Ed and I flew back from Tallahassee one time... And he said to me, Holmes, you know the public will never understand, never realize what we did in this teacher walkout. How we saved the whole damn thing.

Mr. Braddock's view of the public. As chair of the school board during the time of the strike, Mr. Braddock was the point man for the media and the public. He remembered:

That was a tenuous time though. That's probably the roughest three-week period that we'd gone through. My phone rang off the hook at midnight, at two, three, four o'clock in the morning. It was ringing and ringing. Parents were livid. People were just crazy. They'd lost a babysitting service, see... They weren't concerned about the problems in the school system. They weren't concerned about the problems that caused the walkout. They were only worried about the babysitting service and they were having problems.

This somewhat disdainful attitude toward parents and the public in general is often reflected in the transcript data. On one occasion he commented:

I am not a great fan of parents. I make no bones about that. I think that if they would just leave us alone, we'd be a better school system.

This perspective reflected Mr. Braddock's frustration with what he viewed as the self-interests of parents and others in the community. He felt that parents were only concerned about school board policy issues when they had an impact on their own children. Further, these comments also reflect Mr. Braddock's view of himself as an elected member of a public agency charged with the task of representing the interests of all children in the Miami-Dade community. As such, his concerns were focused on what was best for all, rather than on individual interests. 


\section{Importance of teacher professionalization as an element of Mr. Braddock's}

perspective. When I asked Mr. Braddock how he wanted to be remembered, he stated:

I would like to think that certainly old-timers-and there again, they're leavingwill know the role that I played in the teacher rights and employee rights over the years. I wasn't the only one. Obviously no one does it only, but I guess partly because I've been here longer than anybody else.

This concluding statement certainly reflects the value that Mr. Braddock placed on teacher professionalization as an element of his school board career.

Desegregation

The desegregation of the Miami-Dade County Public Schools was the next major controversial issue that Mr. Braddock became involved with, and transcripts of our interviews illustrated the importance of this theme. It was the largest single issue that was discussed throughout the interviews, perhaps because of its significance for $\mathrm{Mr}$. Braddock on both a personal level and a historical one.

Historical background. Mr. Braddock began our discussion with some historical background of the times:

Desegregation which was a major issue. I was very interested in that. That was a major issue. It started in the mid-sixties... See the south was de jure segregated. Segregated by law, so those laws didn't get changed until the Supreme Court invalidated in '54. That invalidated school segregation. And then it said, They shall proceed with all deliberate speed. Well, deliberate speed was all deliberate and no speed! And we're down here, just before I got on the board, two schools were integrated - Orchard Villa and Air Base... Then the state of Florida passed the Pupil Assignment Law... I think it was the '54 legislature that passed what was called the Pupil Assignment Law which was an attempt to integrate but kind of a delaying tactic. It satisfied what they felt was the Supreme Court decision. And that was designed to integrate as little as possible and still meet the laws. And that was called the Pupil Assignment Law and called pink-what did we call them-we called them pink slips. You could come in after the first or second day of school-I can't remember the rules now-and you could pink slip into another school. It was a way of delaying so whites could get out if they got put with 
blacks and blacks could get in a white school and so forth. For a while it passed
muster.

Desegregation of the local school system. Mr. Braddock went on to recount the manner in which the Miami-Dade County School system was desegregated and his role in the effort.

And we did that all the way up until the late sixties when all of sudden we got hit with a full lawsuit on desegregating the school system which I guess was in '69, I think it was... We were in state court first... The State vs. the School Board, I think it was. Basically it was Mays. Mays was the centerpiece of it. And uh, we were in the state court and David Popper, who was the judge, ruled against the plaintiffs. But the school board - and I was chair at the time-I turned the case right over to the federal court and got it introduced into federal court. And then we were desegregated through the federal court... But that was ' 69 , I believe. The case may have been filed in ' 68 or ' 69 , but I was chair in ' 69 and ' 70 , ' 71 , '72, '73, '74. I was chair for a long period of time in there during the whole desegregation thing.

Having explained his understanding of the basis for the desegregation of the

Miami-Dade County Public Schools, Mr. Braddock discussed the method by which desegregation was achieved:

So we had a two-part order. The first one said that we would desegregate the faculties first. And the school board worked with the union and Tornillo. It was still FEA then, it wasn't UTD... The judge said - the ruling came just before Christmas, and he said make it immediately. We appealed to him. Instead of making it then, could we make it January at the end of the first semester, since that was a cutoff point. So Judge Atkins said, Yeah that made sense. He had no problem holding off two or three more weeks. So then we worked with the union. If a faculty member voluntarily agreed to change, they could pick their school. Any white faculty that volunteered could pick the black school they wanted to go to and the black faculty could do the same thing. And then-because the judge gave us percentages of what we had to do-and then, if that did not do it, then we had to assign them starting second semester. And they had, I think we gave the teachers like Christmas holiday and maybe a week after that, because we couldn't give them until February. And so, I don't remember what percentage voluntarily desegregated themselves, but there were a number, maybe 15 or 20 percent, I don't remember. Then we had to mass assign them. Of course that's when all hell broke loose because we just arbitrarily moved teachers then... We just moved them because we had to move what we had to move... Personnel did it. It had to 
be flexible and the union worked with us on that. Tornillo worked with us on that because he knew it had to be done and he supported it... And you had to get the right kind of teachers, the right subject matter teachers in those areas and so forth. So it was a difficult job for staff to do. It was difficult... So we made the transition at semester break... The kids didn't get shuffled until the end of that school year. We did the faculty first.

Mr. Braddock as a southern desegregationist. Mr. Braddock then shared his thoughts as to why he thought he was successfully able to steer the school district through this difficult time:

Most people, many people might have said they credit me with the fairly smooth integration that we had. Now, I've got a ton of editorials and they each want to give me credit for it. Whether that's true or not, I'm sure that it's not totally true. No one person got us through desegregation in a relatively calm way. No one person did that. I happened to have maybe been the point person... But I was a native born Southerner who was espousing desegregation. Ah, so the Southerners couldn't call me Yankee Carpetbagger, see. And to some of them, I was a son of a bitch, but I was their son of a bitch, see!

Former school board member, Janet McAliley also referenced Mr. Braddock's background as being significant in light of his stance on desegregation. But whereas Mr. Braddock saw his southern upbringing as contributing to his success on addressing the desegregation issue, Mrs. McAliley viewed his actions as "remarkable" for a southern man. She recalled:

Well, first he is a southerner. I think he was born in and certainly grew up in Florida in a small town upstate, and the fact that he has provided so much leadership on desegregation was really remarkable for a person of the group that generally opposes something, in this case southern man. And many traditional southerners including a number of people in my family and my husband's family opposed school desegregation. For Holmes to provide the leadership from his background was really remarkable. He was steadfast and he spoke out fearlessly. And I've always admired that very much in him. 
Influences on his desegregationist position. During our interviews, Mr. Braddock

recalled a particular childhood experience as significant in his transformation as a desegregationist:

But I think back as a kid, there were things to me as a kid that were hypocritical... As kids you are going to think about things. Things are done, you want to know why. I'll never forget as a kid, my grandparents on my daddy's side before the Crash had some money. Not wealthy in the Rockefeller sense. But in the little small town of Sebastian, Florida, they had money. They lived in a great big house that's still there. A two-story house, a beautiful two-story house. They were on a grove, a citrus grove. They also farmed... They had this great big beautiful house and big dining room. A big long table. My granddaddy sat at one end and grandmother sat right beside him. I think it must have sat twenty people at once. It was a big table. Big kitchen. Huge kitchen. Irene was the cook... We could go and sit down and eat with Irene at the kitchen table, which we did a lot of times. She'd fix us a bowl of beans, we'd eat there with Irene. But she couldn't come and eat at the table in there at all. She had to serve. She's not allowed to come there and eat, see. And that, now and then, would flash through your mind as a little kid. It would flash in and out at the same time. And I'd say, How come we can eat with Irene here, but we couldn't eat with Irene in there... Those kinds of things that flash through your mind as a kid.

Mr. Braddock's memory reflects an unusual type of moral introspection. At a time when segregation was simply a way of life for southerners, both White and Black, Mr. Braddock's thoughts are indicative of a strong character and an overriding concern for the fair treatment of all individuals. This moral foundation is clearly reflected in the analysis of the variables of his perspective.

Mr. Braddock recalled another childhood memory that had a major effect on his segregationist upbringing:

Up in Georgia one summer, I was six or seven, I'm not sure, and I'm out in the front yard with a little black kid. We were wrestling. I mean really wrestling. Not fighting wrestling, but we were wrestling and having a hell of a time! And my granddaddy came out and God Almighty he bellowed at me. And when my granddaddy on my mother's side bellowed, he was awful! And of course the little black kid, man he took off! My granddaddy ripped me a new one. He said if he ever caught me doing that again, he said what all he'd do to me. I said I would 
never do that again! And I didn't. But I said, Hell, we were having a good time, see. The kid and I were. He was black and I was white, but I didn't care. Well, that didn't make sense. That's the kind of thing at six or seven years that flash in and flash out of your mind. So all I had to do was think back to some of those things that didn't make sense. So along the way I changed.

\section{Other influences on his desegregationist position. Mr. Braddock also}

acknowledged the role that his first wife played in the desegregation effort:

I give my ex-wife some of that credit. She had been very strong on that [desegregation] also... she was from the north she hadn't gone through it. So she was not schooled with desegregation and I was schooled as a segregationist. And I was brought up a segregationist. Everybody in the south was. That was all you knew. For blacks as well as whites... So I had to go through that metamorphosis, so to speak and change... No question about that. And my ex-wife helped in that. My ex-wife did her master's thesis at Mount Zion Baptist Church here. We attended that church every Sunday for like a year, which was totally unheard of in 1949. ' 48 or ' 49 . It was absolutely totally unheard of to attend a black church in a black community. A white couple. And we went down there and attended that church. And then she did her master's thesis on that church. And every Sunday night after the church service we would go over to the pastor's house who was Ed Graham, who has since died. We'd go to Ed's house for coffee and cake or something which in 1948, '49, '50, well my God, you just didn't do that, see! Ed Graham had gone to Columbia. He was a South Carolina black who had gone to Columbia, so he'd been in an integrated society in Columbia. He was the pastor of Mount Zion... She [Ruth] had to get her thesis title approved by Ed. I say Ed, he approved it for the church. The church membership was not literate enough. Most of them in those days, blacks weren't very literate. The title of the thesis was "Assimilation and Accommodation Problems for Native-Born and ForeignBorn Blacks at Mount Zion Baptist Church in Miami, Florida." And that had about half Bahamian Blacks and half Georgia Blacks. They were either from there or their ancestors were there. And they were two distinct groups. If you and I walked in there, we wouldn't know it. They all look black. This side of the church sat Bahamians and this side sat the so-called Georgia Blacks. And they didn't necessarily get along. But they were all black and nobody else would know the difference. So Ed Graham thought [that] Ruth could not do anything or get any support at all unless she had some credibility. So we spent a year, year and a half going to church every week so she could get some credibility. The blacks, they still don't some of them, wouldn't open up to whites at all. They just won't talk to whites... And so Ed says, You'll have to come in here and build up some credibility before they'll even talk with you. So then Ed helped her design a questionnaire and go through the department at the University... And so they devised this questionnaire which then she took to both groups and interviewed 
them and so forth. She got enough interviews for the basis of her thesis. And so I was part of that.

From these comments, it seems evident that Mr. Braddock's own opinion of school segregation was reinforced by this extended opportunity to worship and interact in the Black community.

Personal and professional costs of his desegregationist stance. As chairman of the school board during desegregation, Mr. Braddock was often the object of public recriminations. He recalled the emotional climate at the time:

Well, all hell broke loose! I got threatened, death threats, all kinds of things. I mean it was wild! It was wild then! It doesn't seem possible that that was only twenty-seven, twenty-eight years ago, but it was... I had death threats, I had stuff turned over to the state attorney. Mailboxes blown up as a warning. The phone rang off the hook with calls in the middle of the night - three o'clock in the morning... the community was following by all of the lawsuits and everything. So they knew what was going on, see. And then of course our meetings were televised... But it was all over the radio, it was all over the TV. In those days when I was chair, I guess I'd be interviewed three or four times a week. The TV cameras would be at my house, see, because that was the big news. Parents were going wild! Walkouts, boycotts, blocking traffic and everything you could think of, see. White parents not wanting to send their kids to a black school and black parents not wanting to send their kids to a white school. More of the other way than the latter way. It was wild... One night Bill Lehman and I got escorted out of a meeting at Cutler Ridge Middle School because our security escorted us out of the back door because they uncovered, they felt, some weapons in the audience. The audience was just wild, screaming and hollering and everything, so they escorted us out the back door to our cars and got us out of there. They didn't want us to get shot or something... So that was a heavy hard time.

With the majority of the community against him because of his position on school desegregation, Mr. Braddock was often publicly denounced. During the interviews he acknowledged the personal costs that arose from his position on desegregation:

So, ah, I caught a lot of hell for it. Had my life threatened and everything. I do have piles of letters and editorials and things. Even the Christian Science Monitor did an editorial on me and Carl Rowan did an editorial on me years ago... I've got tons of articles stored in there that I have not sifted through... I did 
save a lot of letters. At that time I was getting letters from all across the country. I had one letter, people would just say, Holmes Braddock. Dade County, Florida. And I'd get the letter, see... At that time we were more visible I guess than we've ever been... In fact, it was a funny thing, a poll was done and the most recognizable name in Dade County was my name, which would not be the case today at all... In those days, we were the news all of the time. Radio and television. There was no end to it.

A particular story illustrated Mr. Braddock's calm approach to the personal attacks that he received:

And I figured I could always outlast them. But if I got a phone call at 2:00 in the morning, my wife would take the call and take the number. He'll call you back. You can rest assured he'll call you back. The next morning I would call him at 2:00 in the morning. He'd say, Why are you calling me at 2:00 in the morning? I just figured that was a good time to return your call. That's when you'd be up. And he's sound asleep. So okay, I returned your call. That's probably the last time I ever had a phone call from him.

In a 1969 Miami News article entitled, "Man on the Hottest Seat in Town," Mr. Braddock's position during this time was corroborated, "At the peak of the desegregation crisis, he [Mr. Braddock] averaged 40 calls and maintained a schedule that, according to his secretary Mrs. Grey Sherwood, 'kept him busy with a capital B.' His business partner, Ronald Shayne, said that Braddock 'Must be suffering from a financial backlash because the school board has always come first - even before family and finance' (Miami News, 1969).

This same article also illustrated Mr. Braddock's family's point of view. According to first wife, Ruth, “'He takes all his calls, bless his heart, and isn't satisfied until he returns the last message,' she said. 'But sometimes when they start coming during supper or when I'm trying to do the dishes, I could just scream!'” (Miami News, 1969). 
When asked about the children's reaction to his school board activities, Mrs. Braddock continued, "They lived through the teacher walkout, so they can live through anything. Bobby just gets tired of answering the phone" (Miami News, 1969).

From these comments, it is clear that Mr. Braddock's leadership on the school board had a significant impact on both his personal and professional life. It also seems apparent that these personal costs were borne by his family as well as himself.

Significance of his leadership on desegregation. I asked Mr. Braddock what he thought about Dr. Wayne Blanton's comparison of him to Dr. Martin Luther King, Jr. He remarked:

I don't know if I did what King did or not. He was a black taking on a white establishment. They were liable to kill him, which they did. I never thought I'd get killed. Maybe if I had thought that, I wouldn't have done it. I never felt threatened although I got threatened, I never felt threatened. Now I'm sure King and all those black leaders have to have-and even now-feel threatened sometimes. Although it should be getting less and less.

This comparison of Mr. Braddock to Dr. Martin Luther King, Jr. was also reflected in a personal note from a constituent, Mrs. Gary Sher. She wrote, "Martin Luther King 'had a dream' and it is men of your caliber who will make his dream a reality."

Commitment to the desegregation of the school system. During our interviews, I asked Mr. Braddock if there were any failures in his career. He acknowledged one that was related to the desegregation of the Miami-Dade County Public Schools:

Well, things I wished had gotten done, didn't get done. I wished we had desegregated every school in the county, like they did in Hillsborough. But, I had the votes at one time and lost them. The court order came down and integrated, or desegregated, I guess they're not quite the same, all but either 28 or 29 schools. After that I got the board, or the majority of the board, to direct the superintendent to draft a plan that would integrate every school in Dade County. The people 
were going ape - those who had not been in the desegregation... absolutely wild! I think had we done that then, we would be a far better off system. Now, I guess you could probably never do it now. That was probably the most disappointing thing.

This position was reflected in a personal viewpoint written by Mr. Braddock and published in the Miami Herald. In the 1973 article, Mr. Braddock stated, "I think integration is integration when every school in the Dade County school system is totally integrated based on figures somewhat near the percentage breakdown of white and black in the county as a whole. Until this happens, we will continue to have our winters of discontent and our white flight. Our poor people who can't flee and the whites who have the money to run but choose to stay to help save the school system will be bearing the brunt of what little integration or reverse segregation exists. In fact, it's this reverse segregation that I believe is the future for Dade County instead of continued integration. And therein the tragedy lies. Without continued efforts toward total integration of every school in our system, I truly believe we are headed for segregation all over again" (Miami Herald, 1973).

Mr. Braddock spoke out very vocally on the issue of busing for desegregation purposes stating in a Miami Herald article that he was tired of "lying Southerners." $\mathrm{He}$ stated, "Any Southerner who is opposed to busing of school children is lying. I was cross-bused for three years and I loved it and my family loved it. I was bused 16 miles to an all-white school, past an all-Negro school that was closest to me" (Education Daily, 1970).

Public opinion of his desegregation stance. These statements won Mr. Braddock both public support and vile recriminations. In a telegram to Mr. Braddock, Willard T. 
Fair, President of the Urban League of Greater Miami wrote, "I was very impressed with the statement you made in the January 21 Miami Herald regarding busing for desegregation purposes."

In another telegram, Edward Grafton, President of the Greer Miami Coalition stated, "Thank you for your time and excellent leadership in the efforts to solve the integration problem in our schools."

And Ralph Lloyd of the American Federation of Teachers wrote, "We commend you on your leadership in your statement regarding school bussing for desegregation and Governor Kirk's defiance of the Federal Court."

On this point, Mr. Braddock also had his critics. One unsigned letter addressed to "Emperor Maximus Braddock" stated, "Just be against busing and pollution and for motherhood and you can be elected to anything... you and your yellow kind are the cause."

Another voter, Tony Martin, responded similarly, "I heard you, a peewee, criticizing our president because he failed to agree with you on massive busing. He does not happen to be a damn radical liberal like you wanting to bankrupt the school system. The public would be blessed if you would resign and then get lost. You are a liability to the county."

Mr. Braddock's attitude toward all of the public sentiment expressed during desegregation was perhaps best expressed when he was quoted by Miami News, "No matter who's raising Cain at me, he doesn't cost me one minutes sleep. The price of prestige is the guff you have to take" (Miami News, 1969). 


\section{Others' perspectives of desegregation as an element of Mr. Braddock's school}

board career. During secondary interviews, former superintendents Alan Olkes, Octavio

Visiedo and Joseph Fernandez all pointed to Mr. Braddock's significant role in the desegregation of the Miami-Dade County Public Schools:

Alan Olkes: Desegregation of the Dade County Schools was almost a single-
handed effort.

Octavio Visiedo: Unequivocally. Unequivocally. I think if he has a signature, I think that was it. He stood up against incredible odds and forces because he genuinely believed that was the right thing for children and for this community. And you know in the end, he's been around long enough that it was sort of validated, but at the time he was not a popular emperor... We did the desegregation. I didn't live that, but I can tell you that, I mean that was a personal-he was in personal jeopardy, there. I mean that was not play stuff, or somebody saying, I'm going to write you a nasty letter. Personal jeopardy...He ran a campaign that allowed him to become elected even though he literally went against the sense of what everybody in the south was then saying. Desegregation. And I would have guessed during that election that his chances of being re-elected were nil. I supported him and other people supported him... But I think the people sensed that whether they agreed or disagreed, they were getting a representative that would always tell it like it was.

Joseph Fernandez: I mean Holmes was probably in my estimation one of the most courageous board members during the early days of desegregation. When the community generally was opposed to it, he put his political life on the line many times and voted in favor of the faculty integration and the student integration... So it was very hard politically to survive those things, and he always did. I mean Holmes is really when you think about it, it's a miracle of his political survival skills.

Each of these secondary sources corroborates the important role that Mr.

Braddock played in the desegregation of Miami-Dade County Public Schools. Cognizant of the political realities of school board membership, it appears that each of these former superintendents admired Mr. Braddock's personal courage and integrity in the face of public opposition. These personal qualities are distinguishable throughout the narratives and are further discussed as variables of Mr. Braddock's perspective. 
Former school board member Mrs. Janet McAliley recalled Mr. Braddock's position on desegregation as a pivotal point in their relationship:

In 1971 I think it was when we were beginning to desegregate the school district. Well, I guess it was earlier than that. And my husband and I both really believed in the desegregation of the schools and our children were in the schools. We also were very involved in politics and we were going to have a party along with another friend who had a houseboat at Dinner Key. We were going to invite several of our favorite candidates to be there and introduce them to all of our friends and help to raise money. And my husband Tom said one night at dinner, We ought to ask Holmes Braddock to come. He's the most courageous man in Florida politics today because he was speaking out and voting in favor of desegregation and a lot of people were adamantly opposed to it. And anyway, we didn't know Holmes except by reading about him in the newspaper and so we called him up and asked him if he would like to come and be one of the honored guests. And he did.

Again, Mr. Braddock's strong position on desegregation seems to have distinguished him from other political figures of the time as an "honored guest." And again, courageous is the most apt word used by others to describe him.

Mr. Braddock's legacy. Toward the end of our interviews, Mr. Braddock reflected on his legacy with the Miami-Dade County School Board:

A lot of things have been forgotten over time. Desegregation will probably be the first thing that will come to mind. Of course as more and more of the blacks die off, the new blacks won't know. There are a lot of new blacks out there now. In fact Cobo was saying the other day-Cobo told me, I don't remember, it might have been during my last campaign. Somebody came up and she was against me. Mr. Holmes, she said, He's a redneck. He [Cobo] says, What do you mean? Because she had only been in town four or five years. She's from New York. But she says, All you've got to do is listen to him. He's a redneck. Listen to his voice. Well, I guess I've got some southern accent. She didn't. So he supposedly set her straight. She obviously didn't know. She obviously didn't know what she was talking about. She hadn't been here, see. She didn't know any of the history of the desegregation in Dade County. And because I've got some southern accent, I guess she equated anyone with a southern accent with being rednecks or segregationists. So as the years go by, there will be some that I hope will remember that. 


\section{Bilingual Education}

As a result of the Cuban migration to Miami in the late sixties and the influx of Spanish speaking children into the Miami-Dade County Public Schools, Mr. Braddock recognized the long-term economic impact that the Hispanic community would have on the county. This vision of the future prompted Mr. Braddock to advocate for bilingual education for all children at a time when the issue was not a popular one. This issue of bilingual education was the third element of Mr. Braddock's perspective on his career.

Initial policy efforts. Mr. Braddock recalled his early efforts to promote bilingual education:

Another thing I tried to do, and I knew I would never get the votes but I tried, I wanted to make us a bilingual school system. Make the system bilingual. Not just English as a second language or have some English kids, Anglos learn some Spanish. But make it a bilingual system. It would have taken some doing. It would have taken some resources. There is no question about that. I thought that we'd have been a much better system as a result of it. I thought we would have been teaching the kids what the kids needed to know. I look upon it, and still do, as a survival skill. I think any kid in Dade County who does not know both English and Spanish and now of course French has come in, Haitian-Creole anyway... Any kid that doesn't have those two skills, many of them are going to have to leave Dade County. They can't survive. If you only speak English in this community, you only have access to about half of the community. If you don't speak Spanish, about half of the community you can't function in. You can't socialize in it. Yeah, you can go in and by a tank a gas, but basically you're shut out from half of the community, if you don't speak Spanish. The Spanish kids will learn English. They've got to. They can't survive without it. So they have to learn English. So then who gets the jobs? The jobs will come to the person who has both languages... So I took the position, that for survival skills, for our kids it was like Driver's Ed, we'd put survival skills in. What about a bilingual school system? So when kids get out, they all speak both languages.

Comfortable in both languages. Now some will do it better than others. That's to be expected. Right now we've got some kids speaking English better than others. Who are Anglo, you know! So my position was, then when the kid gets out the kid has a choice whether to stay or go. If he wants to leave, fine. That's freedom to live where he wants to live. At least the child has that choice. 
Another controversial policy position. Mr. Braddock's position on bilingual education was certainly not a popular one. But at a time when many native Miamians were simply alarmed by the growing Hispanic community, Mr. Braddock had the foresight to assess the impact of this population trend. Just as he viewed school desegregation as an equalizing factor, Mr. Braddock believed that dual language proficiency would not only provide equal employment opportunities for all graduates in the future, but would generally contribute to the economic development of Miami.

His position was noted in a 1975 editorial, "School Board member Holmes Braddock is absolutely correct in saying that Dade County students in this age, should be prepared to become 'citizens of the world' through exposure to at least one other language" (Miami News, 1975).

With this rationale for bilingual education, Mr. Braddock proposed the initiative to the board:

But there were about 32, 25 or 30 leading Chamber of Commerce people who endorsed my proposal. Although when it came time to, when I brought it up at the board, only one showed up. All the others had a reason they couldn't get there. Because the fur was beginning to fly, they were getting a lot of flak everywhere. And it didn't pass the board... Walter Cronkite came down. He sent his person down to do an interview with me, and it was on CBS then. I don't know why. I thought, they filmed part of the meeting and then they came out to my business and cut a tape... Funny thing, when I said those 22 or 23 didn't show. But there were a number of Hispanics who showed, Maurice Ferre being one of them. And I pointed out then and many times, the strange thing was that the people that supported it were the ones that had the most to lose. And the ones that didn't support it had the most to gain. Hispanics had the most to lose. As long as Anglos remain dumb, they can't speak the language. And the job market favors the one who speaks both languages, which is the Hispanic. The one that had the most to gain is the one that stayed away. But there were a number of Hispanics that spoke. Probably I'd say another half a dozen or more. I remember Maurice was one who spoke. And he was mayor of Miami at the time, I believe, and of course he's bilingual... I didn't invite anyone. I've never been one to stack an auditorium... I figured, if I can't sell it, then it won't get sold. And sometimes 
it doesn't get sold. But I'm not going to stack the auditorium. But there were I'd say about half a dozen, maybe a dozen Hispanic leaders that did come down there and endorse it and support it. And I say it's funny, the very ones that had the most to lose were the ones supporting it.

Mr. Braddock's recollection of this event reflects the political irony of the situation. With himself as the exception, no other Anglo politician had the courage to support this bilingual initiative. And while Mr. Braddock did have Hispanic support, he believed that they supported the initiative for different reasons. Additionally, his comments about "stacking" the auditorium also seem to reflect his disdain for political machinations. It seems apparent that Mr. Braddock saw his role from a moral perspective rather than a political one.

Corroboration of his perspective. Dr. Joseph Fernandez also remembered this issue of bilingual education as an example of a policy that Mr. Braddock was not able to establish:

I thought it was very important for Spanish, particularly in Miami, to be a language that kids learn. Not so much Spanish kids. All you've got to do is pick up the want ads and you see how important it is to be bilingual in our community. Our community! My old community! And I thought it was important, particularly for black kids and for white kids, you know non-Hispanic white kids to learn Spanish. And I pushed and pushed to get it in the early elementary school... And that was not popular, believe it or not. A lot of the population, black and white, felt that you know, the Hispanics are taking over. Here's a Hispanic superintendent pushing that agenda and you know Holmes saw the light of that. He really saw the importance of it and was the real advocate for it... He was really a visionary in terms of the impact of it down the road. He wasn't always doing things for the moment.

Not only does Dr. Fernandez' recollection corroborate Mr. Braddock's perspective, he also identifies Mr. Braddock as a visionary. This description seems relevant in light of recent efforts to institute bilingual education programs in all MiamiDade County Public Schools 
Mr. Braddock's perspective on recent bilingual initiatives. I asked Mr. Braddock about the new momentum for bilingual education supported by the One Community One Goal initiative:

We couldn't get any momentum then... but now we've got more Hispanics in more leadership roles now and they are pushing it. I was on the Chamber committee a couple of years ago. Bilingual committee. About three years ago. Before One Community, One Goal. And the chair of that committee, I can't think of the name of this lady, were getting more Hispanics involved. They were pushing this. Of course now though, the more people that are going to benefit now are Hispanics because there aren't more than about thirteen percent Anglos in the school district now. The people and kids getting out of school, if they're not bilingual, in other words, there are so many things that you can't do... If you know both, now you can have access to the whole community socially, the whole community employment-wise... So, I wish it would have happened years ago, but it didn't. So. Maybe I'll win before I die. I won't win, but maybe the thing will go through... There will be some that will I hope will remember that and will remember my stand on bilingualism, although it never got to the point where I thought it would. But someone will remember the efforts.

Recently we see that someone did remember Mr. Braddock's efforts. On the occasion of his retirement, Mr. Braddock was noted in a Miami Herald article for his position on "bilingual education when few backed the concept." In the same article, current school superintendent, Mr. Roger C. Cuevas, remembered, "He's been on the cutting edge of education on such issues as bilingual education" (Miami Herald, 1999).

Significance of bilingual education as an element of his perspective. During the secondary interviews, I asked each of the participants to recall some of the significant issues during Mr. Braddock's tenure on the board. Although she did not expound at length, Mrs. McAliley identified "bilingual education" stating that "he was always very supportive of [it]." 
Octavio Visiedo also cited this element as being significant. He commented:

Well, it wasn't during my term, but the other one I would add is bilingual education. I think it's so ironic that part of the political warfare that was leveled on Holmes was regarding - was from almost the Hispanic community, when you consider the fact that he was the only Anglo that really stood up for bilingual education at a point in time when it was kind of like an Hispanic issue. And against all kinds of odds and against all kinds of other posturing from other school board members, and so his contribution in that arena is incredible.

And former superintendent Alan Olkes acknowledged Mr. Braddock's own personal disappointment at the failure of this initiative:

I think that his push on bilingual education was the right direction and was right, but it just has never - he firmly believes that everybody in this town should be bilingual. And I think that's been a disappointment to him. It's never climaxed with that.

\section{Athletics}

Although not much interview time was spent discussing athletics, Mr. Braddock's position of support for school athletic programs is well known in the Miami-Dade community. As such, school athletics constituted the fourth element of his perspective.

Personal involvement with community athletic programs. Mr. Braddock recalled his own involvement with community sports:

I had been active in sports in town...I went over to the Howard Palmetto League. I was there from ' 59 through ... I coached Legion ball in ' 74 . I coached from the youngest to the oldest. That was the American Legion ball. Then I coached semi-pro team in '78 and ' 79 ... I always like sports. Baseball was always my favorite sport, so I started coaching the kids and I progressed up. I knew a fair amount about the game, not as much as the professionals of course, but far more than most fellows who know about it, knew about the game, so... I spent a lot of years in it.

Athletics as a school board policy issue. Mr. Braddock saw his involvement with athletics as a contributor to his election and as a policy issue for the School Board: 
And I had a broad base of support from within the athletic community. A lot of visible people... Athletics was getting hammered by so many people and so forth. I ran on a pro-athletic platform, where we could pay some schools to have a good solid athletic program which we had. But there were some community attacks on them, I believe. This was at the time, shortly after Sputnik. Everybody thought we should be putting more money into academics, less money into athletics. Well the point was we were putting very little into athletics. Even less than I thought we were! We were really putting nothing into athletics other than coaching supplements and/or substitute days if the coach had to go out of town for a ball game. But we were paying no... right now, we pay some transportation money, pay security money. We've got a lot of money in different places. We were doing none of that in those days. No uniform money. No nothing. No nothing. Everything was strictly internal funds and what the athletic team could raise and through gate receipts which was basically only football. Basketball drew a little, and that was how they took a little money in. The rest of it was all from car washes, doughnut sales, booster clubs and those kinds of things.

From his comments, it appears that Mr. Braddock viewed the public as being both misinformed and misguided. The fact that so little public money went to support school athletics negated the argument that this money would be better spent on academics. Additionally, his comments also seem to suggest that perhaps more public money should be spent in this arena. The tone of these comments also suggest that Mr. Braddock may have felt a sense of pride at the success of the athletic programs in spite of such little financial support.

Significance of athletics as an element of his perspective. Mr. Braddock's role in promoting school athletics was also noted on the occasion of his retirement announcement. In a prepared speech, he remarked:

Believing in the validity of equal access to all sports for female as well as male athletes, I proposed and the Board passed the creation of the Citizens Athletic Advisory Committee to assist us in reaching that goal... Significant changes include: 1) The appropriation of money for female athletes (prior to Title IX), 2) The elevation of coaching supplements, 3) The hiring of full time athletic directors, and 4) The designation of athletic directors for oversight and coordination (no coaching duties). 
As a significant issue, athletics were also discussed during the secondary interviews. Alan Olkes remarked:

I happen to have seats at the University of Miami football games in the same area that he's [Mr. Braddock] in, and we often see each other... The other thing that he has always stood up for, and it has helped to make our schools, is the entire extracurricular program whether it be sports, music or art. It didn't matter. He thought there was more to education than just what went on in the classroom and he supported it strongly.

This perspective seems to indicate that Mr. Braddock had a broad view of education and school curriculum. This view also acknowledged the importance of "nonacademic" subjects such as physical education and the arts. Further, this perspective implies that Mr. Braddock understood the diversity of people and recognized that successful educational outcomes can come from many of these extracurricular areas. Finally, it can be surmised that Mr. Braddock supported the inclusion of these types of programs in a public school setting in order to ensure equal opportunities for all students, not just for those who could afford them.

Mr. Braddock's stand on athletics was also noted by Dr. Joseph Fernandez:

Holmes was a real advocate of athletics and the importance of athletics in the school system and a real proponent for sports. I mean Holmes was before Title IX. Really, he really was! He was pushing things before Title IX, before it became the law of the land.

Again, Dr. Fernandez's comments further establish Mr. Braddock as a visionary leader. Mr. Braddock believed in equal access to athletics regardless of gender. And while Title IX has firmly established this policy as law, Mr. Braddock was advocating for equal access long before its enactment. However, what seems even more significant in this statement is the basis for Mr. Braddock's vision. Whether the issue was teacher professionalization, school desegregation, bilingual education or athletics, $\mathrm{Mr}$. 
Braddock's strong stance reflected his compelling concern for fair and equal treatment of all students. This theme constitutes one of the variables of his perspective that will be discussed later.

Mr. Braddock's long-term contributions to athletics were especially acknowledged by the high schools in Miami-Dade County. On the occasion of his retirement, a quilt sewn from t-shirts depicting the mascots from each of the high schools was created and presented to him at one of his retirement ceremonies.

It also seems noteworthy to mention that the majority of annual fund raising efforts to support another of Mr. Braddock's initiatives, the College Assistance Program (CAP), are athletic events and competitions.

\section{Comprehensive Leadership Role}

While the previous four elements of Mr. Braddock's perspective on his school board career, i.e. teacher professionalization, desegregation, bilingual education and athletics, are notable as significant policy issues during his tenure, the final element identified for analysis, comprehensive leadership role, generally characterizes $\mathrm{Mr}$. Braddock's years of public service. His career on the Miami-Dade School Board is perhaps most remarkable for his record of leadership. According to his vitae, Mr. Braddock served as the chairman of the school board in 1969, 1970, 1972, 1973, 1974, 1983, and 1996. He was elected as vice-chairman in 1971, 1987, 1988, 1993, 1994, and 1995. In summary, he served as chair or vice-chair of the Miami-Dade County School Board 13 out of 38 years.

Local leadership. In our interviews, Mr. Braddock spoke about his years as chairman of the school board: 
Now when I was chair, I'd go down there [downtown] damn near everyday. There's just mountains of things to sign. You just can't imagine how much stuff there is to sign... Now, chair now is not as bad as it used to be. Years ago, when I was chair, back in the sixties and seventies, all checks over a certain size, the chair had to sign. So every Friday, the superintendent and the finance person had to know where I was every Friday. So if we wanted to get something, and a check came in and get it in the bank so we could earn interest for that forty-eight hours. That twenty or thirty or forty thousand dollar check that's going to the bank you needed to get interest on. That could be a fair amount of money, see. Any of that kind of stuff, so you always had to have live signatures, both superintendent and the board chair... So, I had to be available all the time on Fridays... So now you don't have to do that. The law's changed. You can have one live signature. And a staff signature... Chair is a lot more work. And I've had it a lot of times. I don't need it. And last year [cite year], I was nominated last year when Stinson got it. That was just a political thing... I didn't have the votes, but I didn't mind coming in on a five-four vote. Losing on a fivefour...Hell, to me the sun's going to rise there and set here whether I'm elected chair or not, see.

From his comments, it appears that Mr. Braddock believed that leadership on the board was not determined by whether you were chairman or not. Further, his comments again reflected his prevalent disdain for the political aspect of school board membership. State and national leadership role. Beyond his leadership at the local level, Mr. Braddock also served in many leadership roles at the state and national level. He recalled:

I was president of Florida School Board Association. And of course I had all the offices leading up to the president. I don't need to go through them. But, I was president of the Florida School Board Association. I was president of the Council of Great City Schools. And I had all the offices, chairs, going into that too. Leading up to president. And then I was on the Board of Directors of the National School Boards Association which is the organization that - there are about 96,000 school board members in the United States. There's a nineteenmember board and officers that represent those 96,000. I served as a board member on that for six years.

Having served in essentially every leadership role on every major school board association in the country, Mr. Braddock's record of leadership is truly remarkable. 
When asked about the responsibilities of these state and national positions, $\mathrm{Mr}$.

Braddock stated:

Well, it's like any organization of which you're the president of. I mean, you're the point person number one. You manage the affairs, I mean there is an executive director so you really don't manage the affairs. The president carries and runs the meetings, carries the leadership role. He's the spokesman for the group. He appears before the national committees, whatever is happening at the time, so obviously due to the visibility of the Great Cities, you are called upon on a regular basis to appear before congressional committees. And I've done that for both Great Cities and NSBA. Testified a number of times, over the years.

From these words, the import of his role as a state and national leader is clearly revealed.

Dr. Wayne Blanton recalled Mr. Braddock's election to the National School

Boards Association and his contributions to this organization:

I ran Holmes twice for the National School Boards Association Board of Directors. Of course, he got elected the second time when he ran for the NSBA Board of Directors. He was defeated the first time. We ran Holmes from the floor and got defeated. Then after that we used a different process, so Holmes got elected to the National School Boards Association Board of Directors. On the national level, what he worked primarily on was one, people understanding the needs of urban boards and two, Holmes has always been probably the biggest advocate of understanding diversity and the needs of minorities. And he has advocated that on a local level, a state level and very strongly on a national level because he understands that urban boards are not the same or urban districts are not the same as the majority of the school districts in the United States. And he was always trying to make sure that the other districts understood their unique needs and I think was very successful at it. You know, he was president of the Council of Great City Schools, served on the National School Boards Association Board of Directors from a very large district-fourth largest district in the country-and time after time he had to explain to people that while that may be right in your district it doesn't work in about twenty-five major districts in this country and would give them the reasons. A lot of Hispanics, minority kids are poor. They need special programs. We've got immigration coming in. Our people can't even speak English. And Holmes was a great bridge between the urban districts and what I call your "more normal school districts" in the United States. 
From these comments it is evident that Mr. Braddock's leadership at the state and local level was predicated on the same concept of fair treatment as his local leadership. And just as in Miami-Dade County, his position on the issues reflected both vision and moral integrity.

Significance of his comprehensive leadership role. Mr. Braddock reflected on the impact that his leadership at the state and national level had on his role at the local level:

Well, I don't think it helps you get elected at all. People don't give a damn...It could make you be a better board member. There's no question about that... Well, I think you understand the total picture of education better. Although I think in a system like Dade County you had a chance to do that anyway because we're a broad system. You deal with rural education and urban education and suburban education. We deal with all those kinds... So we have a leg up on most people, anyway. But this has enabled me to understand the dynamics of a lot education - certainly all the political dynamics in Washington because I spent a lot of time there. I testified before a lot of committees. I spent a lot of time dealing with key people in Washington and the people across the country. Finding out the problems and understanding things.

Through these experiences, Mr. Braddock also acknowledged the important

perspectives of public education that he gained from visiting other school districts:

I visited schools in every major city in the United States and Washington, too. New York, Pittsburgh, Buffalo to Cleveland to Chicago, Milwalkee. Denver, St. Louis, Dallas, Houston, New Orleans, San Diego, Los Angeles, El Paso, Albuquerque, Seattle, Portland, San Francisco, Oakland. Well, there is no question-and this sounds like a bit biased statement and I guess it is because you can't be unbiased, but I don't think any of them measure up to us. But now part of that is that all of those are city systems only. They are nothing but the city. Whereas we've got all of this out in here which is nice suburbs all the way down through here, which they don't have in those big cities... I've visited schools in Washington, D.C., also. Columbus, Ohio. We've had meetings, see, in all of those different cities. And when we've had our meetings, we always have a day schedule where we visit schools. Long Beach, California. I guess it must be, St. Paul and Minneapolis both. Memphis. Atlanta. Of course in Florida I've been through all of them, all the counties in Florida. Norfolk, Virginia... Rochester, New York. 
From these visits it appears that Mr. Braddock deepened his understanding of the role that demographics play in determining school board policy and gained a greater appreciation for the diversity of Miami-Dade County.

Mr. Braddock's leadership at the state and national level was also noted in the secondary interviews. When asked to identify the role of a school board member Alan Olkes and Octavio Visiedo remarked:

Alan Olkes: I think the other thing that you would look for in a board member is leadership. Where Holmes in many ways on the board took somewhat of a back seat to administration-administration would do this if we wanted them to they would go do it - at the state and national level took a very strong leadership role with those organizations. The State School Board Association and the National School Board Association. He had a leadership role in the Council of Great City Schools. He spoke out at both the state and national level on the same types of issues that were inherent in any school district.

Octavio Visiedo: We used to go to these national meetings, I mean you couldn't walk three steps without, Oh, there's, Holmes! Everybody knows him!

Alan Olkes: Everything you go to where you'd run into a school board member from anywhere, I mean anywhere, Iowa, Michigan, it didn't matter. And they'd say, Oh, Dade County. That's where Holmes Braddock is a board member.

Janet McAliley also acknowledged Holmes' state and national roles:

And he of course has been a national leader among school board people having served on the National School Boards Council and he's been president of the Council of Great City Schools. I've probably lost track of all the national offices he held. So he's been recognized in that way by school board folk from all over the country.

These comments acknowledge Mr. Braddock's leadership role at the state and national level and indicate the high level of visibility he had with other members of these organizations.

Significance of his longevity. A significant contemporary issue for school board members, Mr. Braddock gives an example of the high turnover rate of school board members and superintendents in today's large urban districts. 
In other words, so there aren't many big cities, [where] I haven't visited schools in those cities and during those times meeting the superintendent in all those districts. And I didn't know all the board members because all of them aren't active. I knew all the active board members. Now, I probably don't know, because the turnover has been dramatic in recent years. The turnover is really dramatic now. Either they get beat-and it's tough in the big cities. I mean people today, and it sounds egotistical, but they marvel at my ability to stay elected in these times... The next morning I got a call about six thirty from Wichita, Kansas from a fellow board member from there. And then about nine o'clock I get a call from a fellow board member from Idaho, who called. They were all concerned. They had already seen several board members fall sitting on the Board of Directors. In fact the guy that called me from Kansas... got beat at his home board while he was still on national board. He got beat in his local election. He was stunned! He didn't even think that he had to campaign... There were no issues, nobody seemed after him. There was no "throw the bastards out mentality." He was stunned. So they've all been amazed that in recent times, because of all the kinds of problems we've had, see. Maybe we've got a dumb constituency out there, you know. Maybe they can't tell right from wrong, you know.

These comments are interesting to note. While Mr. Braddock seems to show a flagrant disregard for public opinion and politics in general, his longevity on the board depicts him as a tenacious politician. In addition, his comments seem to reveal a sense of pride in his own ability to prevail in a climate where others have failed.

And finally, Mr. Braddock commented again on how his leadership roles at the state and national level have impacted his local leadership on the Miami-Dade County School Board:

So anyway, having done all that, I think it's enabled me to understand education better-the needs of education and the problems with education. Sometimes even the limitations of education. And where I certainly think things are not meant to be in the public sector. That's one thing that I think Renier never understood. Renier never understood that there is a difference in public and nonpublic education. Different roles, different responsibilities. He was trying to make the public system like the private system. It's a different ballgame. Not understanding that there is a difference. Not saying that theirs is wrong, but it's a different role, different responsibilities all together. So I think being active like this helped me understand a lot more than if I would have stayed home. 
Here, Mr. Braddock acknowledges that his state and national leadership has enabled him to view public education from a broader perspective. And while he does not directly contribute this understanding to his successful leadership and longevity at the local level, it seems evident that his understanding of the role of public education enabled him to make good decisions.

Others' perspectives of his comprehensive leadership role. Pat Tornillo concurred with this view of Mr. Braddock's leadership:

I think one of the qualities of a good leader, as I know Holmes has been, is keeping abreast of what goes on in education. Attending conferences which is one of the reasons that Holmes was not a typical school board member because he did attend and involve himself in the Florida School Board Association of politics, and in the National School Board Association. And the Great City Schools. Which was to his credit because that gave him a national and state perspective which was valuable to him sitting as a member of the Dade School Board. So I think that that's another quality I would consider of a good leader.

In these comments $\mathrm{Mr}$. Tornillo directly attributes active participation and ongoing professional development as elements of effective leadership.

Qualities necessary for effective leadership. When asked, Mr. Braddock also identified some of the qualities he believes are necessary for effective leadership:

Well, obviously, I suspect that there are few, if any, who have all what we call the qualities of leadership. I think... there is one thing they use in some vernacular which is an oversimplification. They say leadership has the three " $\mathrm{f}$ " $\mathrm{s}$ ". Be firm, be fair and be friendly. That's an old Lion's thing, but if you analyze it, it has more than really meets the eye on the surface. I think a leader has to be firm. Any kind of leader. In other words whether it's the principal, or it's the superintendent, or it's the CEO, football coach, they've got to be firm. I think you have to be fair... And then I think there has to be friendliness there. Years ago, I think you'd have to emit a friendliness to the organization which they don't transmit. I think you could have two of those, but not the third. And I think ... you've got to have all three to be what I call really successful. I think if you're firm and friendly and not fair, I think you'll fail. Well, obviously, I suspect that there are few if any who have all what we call the qualities of leadership... I haven't seen anyone that had all of them. 
As previously noted, a quality of fairness is a prevalent characteristic of $\mathrm{Mr}$. Braddock's leadership on the board. Additionally, if the word firmness can be interpreted in terms of personal integrity, this quality is another pervasive variable in $\mathrm{Mr}$. Braddock's perspective. And while friendliness is not a variable or element discussed in this analysis, it can be implied by the nature of the comments made by the secondary sources that Mr. Braddock's popularity is partially derived from his friendly and approachable nature.

Examples of effective leadership. Mr. Braddock referred to the superintendency for specific examples of leadership:

The best superintendent I've been around - I guess we shouldn't put this in there - would be Dr. Ed Whigham. Now he was not the most charismatic person, but he was the smartest person I've ever been around. He was absolutely organized all the time. A superb administrator! He could've gone on to something like General Electric if he wanted to or General Motors and probably would have made a fortune. But, he was not the most charismatic person. So he had as his alter ego so to speak, Howard McMillan for whom McMillan Middle School is named after... Ed was not a good communicator. But oh, man, what a superb person he was! So he complemented himself with Howard McMillan... He never was flustered. Nothing bothered him. Desk always completely clean. Everything was done in time. I mean he was so organized, so perfectly organized. He was brilliant, but he was not a charismatic person at all. But you've got to have I think $\mathrm{a}$ - in various times - a strong educational leader. You've got to have a person who's a superb administrator. And I think they need to be bright. You've got to be bright if you want to do the job for any length of time. You've just got to be able to absorb so much. That doesn't mean you have to know it all because that's what you have staff for. But you've got to be able to absorb it and know about it. You may not know the nuts and bolts, but you've got to know about it. And then you've got to be charismatic or have someone who is. We don't have all that right now. And so, those are probably the prime qualities of leadership at this level. You've got to be bright. You've got to be organized. You've got to be able to use your time. And you've got to be able to be firm. You've got to be able to make decisions. 
Other qualities of leadership were discussed in the context of former Miami-Dade

County superintendents:

Some people lead by brain power. They can out think other people. Whigham belonged in that category. People knew that they couldn't out think him. And if you knew that you can't out think somebody, then you better follow them because you're not going to be ahead of them on the thinking side... So Ed could lead-he had two things. Smart and organization. But he had those other things too. But he certainly didn't lead by personality. Sometimes I think the depth of one's personality sometimes can be a leader. If you believe that personality. You can't just be a personality. Roger is a personality kid. So you can't lead just by that. I think that you can lead on personality. I think sometimes on commitment. If you have such a strong commitment on something you can lead the people if they buy into the commitment. Or if the commitment that you have is the same commitment they have, and it's such a strong commitment, I think that you can be a leader. But I don't think that you could necessarily take anyone and say if you have that, that you would automatically be a leader. And I don't think he [Whigham] lead by organization alone although he was probably the most objective of the superintendents that I've seen in promotions. The most objective... There seemed to be fewer complaints about cronyism then. We had a ton of complaints when Fernandez was superintendent of cronyism after Britton. Britton wasn't too much like that. I like Leonard, but Leonard was wishy-washy. Whoever talked to him last could change his mind on something. You never knew when you had a commitment out of Leonard on anything. I remember that Paul Bell had his cronies and certainly OV had his. Although his were better than Roger's. He put Alan Olkes in there. Alan Olkes was a good solid appointment. In fact if you look at OV's, they may have been cronies, but I think by and large they were good appointments. Qualified... I don't care if you appoint your friends. I like to hope that you think you friends are equally qualified.

In these comments, Mr. Braddock not only categorized the leadership style of these former superintendents, but his words also hint at his own personal opinion of these individuals. Again, Ed Whigham was highly regarded by Mr. Braddock for his intelligence, organizational skills and his ability to recognize his own weaknesses and compensate for them. Mr. Braddock's view of current superintendent Roger Cuevas as a "personality kid" is clearly not as flattering and suggests superficiality. Dr. Fernandez is dismissed for his "cronyism" and while Mr. Braddock indicates an affection for Leonard 
Britton, he was certainly not someone that he viewed as being firm. Although Mr.

Braddock cited cronyism as an element of both Paul Bell's and Octavio Visiedo's tenures, he justified it by acknowledging the qualifications of those appointees, such as Alan Olkes.

Mr. Braddock went on to provide a specific example of effective leadership in the superintendency:

You have to be able to move staff when staff has to be moved... Ed Whigham was without a doubt the sharpest at doing that I've even seen in the superintendent that we've had here. You could not tell when he was demoting somebody. You simply could not tell. He was so smooth. You never knew when someone was demoted. You'd get a letter, you'd get an agenda item and there would be a letter in the agenda item. Dear Dr. Whigham, The last three years you assigned me to this particular job or I've been assigned this job, but I just don't think after three years of something, I think I've gotten all I could get out of the job or it's just not the kind of job that I would like and if the opportunity ever comes to get some other responsibility, I would hope that you would keep me in mind... And so we we'd get a letter. But in the agenda item, John Jones is going from say this to this. You don't realize John Jones got demoted. It was Ed's idea, and I concur. That person has still got to be a leader wherever that person's going to be. And if the people over here think that this guy went there because he wasn't good enough to keep that job, they aren't going to think that he's good enough to be their boss over here. In other words, he's still got to have the respect of his employees over here. Now maybe he'll go there and do a good job anyway. Maybe he was miscast here. But regardless, whether he was miscast or not, he still has to go over here, so at least if he can't do it over here, he'd have a shot at doing it. Let the people think he can do it when he gets there and maybe he will do it. But if they think he got demoted, he'll never get a chance to do it. There's no need for the board or the public to know... The public doesn't need to know that. Because they still have to function. And they can't function if you cut the legs out from under them. But Whigham was the smoothest at doing that than anybody I have ever seen.

It appears from these comments that Mr. Braddock had strong feelings about treating employees fairly and professionally. Fairness, as a variable of his perspective, was reflected earlier in his position on teacher professionalization and a leadership quality that he has specifically identified. 
Other examples of effective leadership. When asked to consider others he viewed as being effective leaders, Mr. Braddock responded:

To be honest with you the political figures that I really think are what I call strong political figures have convictions and stick with them. There's people who get things done. In other words, Bill Clinton is exactly-is a guy that can get things done... He's not as strong on his convictions as I'd like, but maybe if he were, he wouldn't have gotten where he is because as I sit back and assess him, I assess him as being an outstanding president. Beyond all this Monica Lewinsky thing... Somebody asked the other day what were the good things that he's done. I said some of things weren't so much what he did as what he stopped from being done. I mean some of the legislation that Congress would have come out with would have been deadly to education and human services and human issues. That Clinton wasn't going to let get by. Either he'd veto them or the threat of veto kept them from coming out. And there's certainly, some of his educational initiatives have been good educational initiatives. Maybe not as strong as I would like, but again he's trying to get votes and you have to get votes... At least Clinton I think did some things. Clinton is smart. He's smart... So I think you'd have to put Clinton in that category.

Mr. Braddock's opinion of Bill Clinton is particularly interesting in light of his own strong moral convictions. And while he acknowledges Mr. Clinton's shortcomings, his remarks seem to reflect an understanding and acceptance of the political realities of the presidency. It is also significant to note that what Mr. Braddock viewed as some of Clinton's successes where the things that he stopped. This reflects Mr. Braddock's understanding of the external factors in the situation that contribute to the success or failure of an initiative. This variable is further developed later in the analysis in the context of his own leadership.

Mr. Braddock points to changes in the political processes over the years as one cause for the demise of strong leadership:

First of all the laws have changed now. The real leaders we had years ago are not there because they can't run. So they run and can't get elected again. They have term limitations and are not there long enough. And again they probably did 
some things that were if not illegal, were certainly unethical then, but hell we didn't know about it.

Personal qualities of leadership. When asked about his own leadership qualities,

Mr. Braddock responded:

That's almost something that somebody else has to assess. Well, it's really hard to assess oneself. I can go by what some things other people have said. I can throw those out. They say that I'm a man of my word. So that's been one thing. I'm not easily swayed. I mean I can be swayed, but first you've got to sway me with facts and information. I'm not usually swayed by the strength of one's personality. I mean if you don't want me to vote for something, you've got to give me some reasons that I think are reasons. Don't just say, Hey I've got a hundred people out here that want you to vote for this. People seem basically to say they trust me. Even those who dislike me. I've had people who dislike me say that they trust me. They didn't agree with me but at least they trust in me. They don't think that I'd double-cross them or anything. Now whether that's leadership, I don't know. I think that could be factored into leadership, I guess. Yeah, and I like to think that I'm fair. And I guess that some people might challenge that. But I like to be-use those old three-firm, fair and friendly. I think basically I'm a friendly individual. I'm not-I like people. That it itself doesn't make you a leader, but I think that it's another factor. I like to think I'm fair... Hell, I'll take a stand against what appears to be the popular stand. I have no problem doing that. I think some say that I do it on purpose, but that's not quite true.

Mr. Braddock's self-assessment reinforces those qualities of leadership that he values, i.e. firmness, fairness, and friendliness. Additionally, it seems that he truly believes that these principles have contributed to his longevity on the board. Because of his firmness and fairness, people can trust him even if they don't agree with him. It also seems noteworthy that Mr. Braddock's self-assessment mirrors the comments made by others.

Effective school board leadership. Mr. Braddock expressed his opinion on the role of an effective school board member:

I think a policymaking leader - well I think that we should be thinking about 2010 for example. And I don't mean think about it all of the time, but 2010-what is 
that twelve years, a little over eleven years away-we've got kids entering kindergarten now who are going to be in the class of 2011 or something. We should be thinking about that. That doesn't mean that we don't think about tomorrow or next year, because you've got to get to 2010. I don't think we spend our time doing that because there are too many board members who are worried about getting elected tomorrow or next year. And they go on the premise that well hell, I can't do anything if I don't get elected. Well, I buy that, but hell somebody else can get there and do something about it.

These bold statements clearly illustrate Mr. Braddock's future-minded orientation. With such a long-term view of the future, his ability to envision the future has enabled him to establish a position on the issues with that future in mind. Understanding this aspect of Mr. Braddock's leadership explains why he has been described as a visionary in his stance on teacher professionalization, school desegregation, athletics and bilingual education. And it is this vision, coupled with those other qualities of leadership that he has identified, i.e. firmness, fairness and friendliness, that has contributed to his successful thirty-eight year leadership as a member of the Miami-Dade County School Board.

Holistic perspective. As previously noted, the four elements of Mr. Braddock's perspective, i.e. teacher professionalization, desegregation, athletics, and bilingual education, constitute significant public education issues during his school board tenure. And while the fifth element of his perspective, his comprehensive leadership role, constitutes a holistic characterization of his school board career, a deeper analysis of that role reveals the variables of his perspective. The discussion of these variables explains the reasons for Mr. Braddock's successful leadership by examining the motivating factors in his decision-making. 


\section{The Variables of Mr. Braddock's Perspective}

In the discussion of the elements of Mr. Braddock's perspective, several additional themes were revealed in the data that were not classified as elements. In contrast with the elements of Mr. Braddock's perspective, these themes were related to the motivational factors that influenced Mr. Braddock's decision-making. The variables of Mr. Braddock's perspective can be identified as the internal beliefs or defined as the moral foundation that have influenced his position on specific issues and have characterized the elements of his perspective. Specifically, these variables were:

1. fairness

2. integrity

3. courage

4. honesty

The influence of each of these variables was alluded to in the analysis of the elements of Mr. Braddock's perspective. His fairness and firmness on the issues is a common thread noted throughout the discussion of each of the elements and is the foundation on which Mr. Braddock establishes his decisions. Additionally, the courage and ability to "tell it like it is" were contributing factors to his successful leadership.

In addition, the data revealed one external variable that had a significant influence on Mr. Braddock's career. This variable, the situational context, was related to the interplay of external forces on Mr. Braddock's leadership. Consideration of this variable is important in order to establish a comprehensive explanation for his successes and failures as a policy maker on the school board. Together, these five variables were the factors that were reflected in the elements of Mr. Braddock's perspective 
Perhaps the most notable variable in the analysis of the data was Mr. Braddock's deep concern for the fair and equitable treatment of others. This issue of "fair play" seemed to permeate all of Mr. Braddock's position on the issues and policy decisions. It also seemed to be a personal characteristic trait that was important to him.

Fairness as a personal quality. Initially, Mr. Braddock describes himself as being a fair person:

I think you have to be fair...I like to think that I'm fair. And I guess that some people might challenge that...I like to think I'm fair.

Similarly, former superintendent, Octavio Visiedo described Mr. Braddock in these terms:

My vision of him is similar to what Alan said. Forthrightness. Integrity. Loyal. And incredibly fair and really committed to education. I mean, I think honestly that's the difference between the board member of the days of the Holmes Braddock and the current board member. Where there is on one side an incredible commitment to children and public education, and now there is an incredible commitment to the political process.

In this statement Mr. Visiedo both characterizes Mr. Braddock and also commentates on school board politics. Just as Mr. Braddock expressed his concern that today's board members are not making decisions on what is best for public education but rather on what will ensure their reelection, Mr. Visiedo seems to suggest that today's school board politics reflect selfish interests and do not contribute to effective school board policy.

Alan Olkes concurred with Mr. Visiedo's characterization of Mr. Braddock and related a personal incident to illustrate the point. 
My recollection is... I had had a serious falling out with who was then superintendent, Leonard Britton. I didn't think it was my fault for what I did, but hey!... And it came before the board and some of the board members were getting into it. And Holmes did two things at that board meeting. First, he reminded the board members that the people on staff work for the superintendent. They don't work for the board. The board should keep their nose out of it. Then he turned to the superintendent and said, You shouldn't be airing your dirty laundry in the press. And it shouldn't be here in front of this board. And he thought it was high time the superintendent behaved like a gentleman and did the right thing. It took guts to do that. Certainly I appreciated it and I told him afterwards how much I appreciated his words, etc. He said, I wasn't doing that for you. I was doing that for the school system because if the superintendent does that to you, he's going to do it to somebody else. He said, Pretty soon we're going to have chaos around here. So it wasn't, you know, even when I was trying to be gracious and say thank you for it, his view of it was, Alright, yeah, I helped you out. But I helped you out because there was a bigger picture. There's a cancer growing here that had to be stopped. That's what I was after.

In this example, Mr. Braddock's commitment to fairness was characterized as objective in nature. Its application was not determined by individual or place, but solely on the situation. This suggests that Mr. Braddock had the ability to detach himself emotionally from a situation in order to base his decisions entirely on the circumstances.

The high value that Mr. Braddock placed upon fairness was reflected again in a Miami Herald article reporting his retirement announcement. Mr. Braddock said that "he would like to be remembered as a person who was fair and 'stood up for those who were disadvantaged"” (Miami Herald, 1999).

In the same article, Deputy Superintendent Henry Fraind described Mr. Braddock in similar terms, [Mr. Braddock] "was firm, fair, spoke his mind and you knew where he stood on an issue whether it was popular or not" (Miami Herald, 1999).

Fairness as an influence on policy making. Former board member, Janet McAliley also used fairness to describe Mr. Braddock's contributions while on the board. She remarked: 
His strong belief, of course, in justice and fairness for all people whether they are people of different races or different language or ethnic backgrounds. He has always been a strong supporter of justice and due process for everyone and so he contributed greatly in that way.

As was noted in the analysis on desegregation, this sense of justice and fairness for all people seems to be an innate quality in Mr. Braddock that is reflected in his early recollections on segregation in the south. It would appear that through his extensive leadership at the local, state and national levels, this understanding of the plight of others reinforced his strong belief in fair treatment and due process.

The desegregation of the Miami-Dade County Public Schools reflected Mr. Braddock's deep concern for fair and equal treatment of all students. In a 1970 Miami News article, Mr. Braddock stated, "[He] would follow any route to assure an equal educational opportunity for all children, including busing" (Miami News, 1970).

This commitment to the fair treatment of all children in the district was the pillar ton which Mr. Braddock hung his political career. It was the strength of his convictions to this single belief that enabled him to take a position on desegregation, regardless of the political and personal costs.

Fairness as a variable of single member districts. The notion of fair treatment is also reflected in Mr. Braddock's perspective of single member districts in the MiamiDade community:

Well, I think it's the worst thing that could happen to us, single member districts. I said that to the court. I said that all along. I think it's the worst thing that could happen to us... because of the parochial nature of what it does. It makes people think of the parochial instead of systemwide. You can see it in the votes on the board. You can see it in the agenda items on the board. You can see it in how the board addresses issues. They're not addressing the issues on a countywide basis. It's becoming increasingly more difficult for a superintendent because he has to 
make decisions not based on what he feels is necessarily good for the system but what will keep each board member happy, see... Very parochial thinking.

In other words, Mr. Braddock believes that single member districts have politicized school board policy-making to the point where decisions are based on selfish motivations with no regard for what is right and fair for all students.

Mr. Braddock used the black community of Miami as an example of the inequity and unfairness created by single member districts:

It's also watered down people's influence. Tremendously. The black community now really only has two board members that they can talk to... But there are only two black board members, so the other ones don't even need to go down to Overtown. Used to, we had to go everywhere and be concerned about everywhere and everybody. And so the black community in Overtown had access to seven board members, had to hear seven board members, and knew seven board members had to pay attention to them. Now, there's only two board members who have to pay attention to them. Two out of nine. The rest of us don't have to pay any attention to them if we don't want to. They can't elect me and they can't unelect me... It's entirely different. Different agendas, different interests, different voting... There's no concern about the rest of the district. Again, these comments can be assessed in terms of Mr. Braddock's position on

ensuring fairness for all. He points out that unequal access to board members now limits a minority community's ability to articulate its concerns. He viewed this issue purely in terms of its implications on public education with no concern for his own political career.

Mr. Braddock's concern about the parochial nature of single member districts and its inherent inequities was also referenced by Dr. Fernandez:

The Miami school system asked me to write a paper before they went to the ninemember board. They asked me to write a paper and make the comparison because I worked under the Miami Board which was seven board members, all of them ran at large. About half of them lived in district, but they all ran at large so they are beholden to all of their voters. Not just to a particular district. And versus New York City where you have seven board members appointed politically... And the difference between the way Miami ran and New York, forgetting the size because New York was over a million students and over a thousand schools, but the difference was that everything in New York City was 
divided by five. You know, you got your Title I. It was divided by five. You got your construction money. It was divided by five, to the five boroughs equally. No consideration was taken always as to where the greatest needs were. In Dade County, the difference was that the board members were all beholden to the entire electorate even though five of them had to live in district. So, they couldn't gang up for example on Overtown and decide not to do something in Overtown because all of them also had to gather votes in Overtown when they ran again. So they looked at things, not in a parochial sense, but in a district-wide setting. Generally speaking. In a place where you have district representation-I'm not arguing that it's bad, I'm just saying that's the way it is-if I represent a specific district, I'm generally looking out for that district. And I generally have a very parochial vision on how to attack a problem. And I want to make sure that I get my share of the dollars for my district. And that may mean that some other district that has greater needs is going to suffer as a result of it. That's the danger of going to the single member district that you have now... I'm just saying that part of the reason for a lot of the good things that happened in Dade is because of the continuity of the board and Holmes was a very big part of that.

Here it is interesting to note that Dr. Fernandez expressed the same concern for minority communities that Mr. Braddock did. While proponents of single member districts point to increased opportunities for minority representation, it appears that both Mr. Braddock and Dr. Fernandez view single member districts as limiting fair treatment toward these same communities.

Wayne Blanton, too, was in agreement with Mr. Braddock's opinion of single member districts:

I believe that Holmes will probably tell you and I will agree that I don't think that single member districts are good for local boards because I think board members should be elected to do what's right for the entire school system and not be parochial in any of their decisions. And when you are only from a single area and only have to answer to those constituents, eventually you have to make a decision that's good only for that district and not worry about the rest of the district. That's why I think single member districts are self-defeating.

From Mr. Braddock's perspective, single member districts were also unfair to those seeking office. He believed that single member districts made campaigning more expensive, and therefore limited the opportunity of some to run for election. 
It actually costs more money to run in the district than to run countywide. It costs more money. One of the reasons they went district is they said it' $d$ be cheaper. But it hasn't been. Because I never did a mailer countywide because I couldn't afford to. But when you get in the district, you've almost got to. And that's expensive.

Fairness as a variable of urban schools. Another example of Mr. Braddock's regard for fair treatment was reflected in his position on large high schools. It is also pertinent to this analysis to note that the reasons he cited were related to athletics which was previously identified as an element of his perspective. Again, fairness can be seen as the common thread throughout the elements of his perspective:

I just think that 3000 is too many. 3000 or 4000 is too many. I am not sure what I prefer. I guess if I were writing the script and money was no object and I could design a school myself, I probably would want a high school of maybe 2000. Because when you get the size that Braddock is-say any school that size-you have one football team. You got one baseball team. You got one basketball team. You have a JV, I mean, but you've got one of everything. So now you got a school and you've got 5000 kids there. But you've got 12 kids playing basketball. Now, if you had three fifteen hundred-sized student bodies, instead of having 12 kids playing basketball you would have 36 or 40 . You'd have 12 or 13 on the squad, so you'd have three times that with the opportunity to play. And the baseball team, the same. Well, you are limited the number of kids that can play. When you get to tournament, it's something like 18 or 20 baseball players is all you can carry on your roster. So now, this high school of 5000 kids has 18 or 20 kids playing baseball... There are some things that don't matter. The band, can expand to whatever size you want. Bands can expand. You can expand the yearbook staff because you'll have a bigger yearbook. There are more things to do, so you could expand the yearbook staff. You can expand publications. If you are printing once a week, you could even go to two a week instead like you've got in a bigger school. You could have twice as many things to report, so you could go to two a week. You could make up the difference of some of those activities. In clubs, you can have as many clubs as you've got kids that want to join the club. So club participation would not diminish in a big school. What diminishes are those activities which are controlled in size.

In this example, fairness is equated with access and opportunity for all students.

In his view, a student enrolled in a small high school had an unfair advantage for participation in athletics over a student enrolled in a large high school. 
Fairness as a variable of teacher professionalization. Fairness was also at the essence of Mr. Braddock's support for teacher professionalization and was reflected in his comments on the fair treatment of employees:

That was a problem in all those schools that weren't air-conditioned... I know a lot of people say, Well kids can go to school. Well, I didn't have air conditioning when I went to school, and I have no problem with that except that you tell the teachers that they've got to work in there. And how many people are working in non-air conditioned places. Nobody unless you work outside! Anybody who works inside, works in an air-conditioned office. So why should you tell teachers and administrators that they got to function in non air-conditioned places, but you are going to function in air-conditioned places.

This example illustrates the breadth of Mr. Braddock's view on fairness. He saw fairness in a holistic manner and was always able to look at the situation in the context of the bigger picture. Even a matter so simple as air-conditioning was viewed by him in terms of fairness.

Fairness as a variable of equitable treatment of students. Another example of the wide range of issues related to fair and equal treatment of students was corporal punishment:

I'm tough on discipline. I could not tolerate-I'm opposed to corporal punishment in the schools, not at home. If you want to wear your kid out I have no problem. I wore mine out. I got worn out too. But I've got a problem with the school system because it's unfairly administered. A lot of it depends on the size of the giver and the size of the getter. If you're a six foot two, two hundred pound AP and you've got a five foot six, a hundred twenty pound kid, he's liable to get some whacks. But if your AP is five six and a hundred thirty-five and the kid is six foot two, two hundred twenty-five football player, you're not going to get any whacks. And right off the bat that means it's not fairly administered. And if you had it in class, some teachers would and some teachers wouldn't. Some principals would, some principals wouldn't. So it would depend on whose class you're in and whose school and all this stuff. To me, it was just so unequal.

Mr. Braddock's sense of fairness to all Miami-Dade County children was not hindered by political ramifications. Octavio Visiedo recalled a particular incident: 
Holmes voted, when I was in charge of attendance boundary committees, for boundary recommendations within his own area where he lived because he believed in the recommendations which, you know, another board member would have taken a hike on it. He [another board member] says, You know, I know you are doing the right thing, but I've got to do it the other way. I don't want these people mad at me. Not Holmes! If he believed in it, he didn't care what the repercussions are. He had courage of his convictions and he would do what he had to do.

Here, Mr. Visiedo suggests that Mr. Braddock demonstrated courage in the face of public opposition. And while his actions do appear to be courageous, the underlying motivation for his position on attendance boundaries was ensuring a fair and equitable education for all children.

Dr. Joseph Fernandez's recollections further support Mr. Visiedo's observations of Mr. Braddock's position on attendance boundaries:

And I recall Holmes coming to those meetings in his district-he represented part of the Kendall area in his district-and taking the heat. Basically saying, Hey, this is the right thing to do. It may not be popular. In fact, I remember people yelling about recalling him and you know, he wasn't looking out for their interests and so forth.

Fairness as a variable of equitable treatment of employees. The Sunshine Law was another issue that Mr. Braddock viewed as being unfair to employees and public officials. He used the evaluation of the superintendent as an example of his position on these laws:

People don't realize how difficult it is to work in the Sunshine all the time... You doggone sure can't assess the superintendent properly... So we don't ever assess our superintendent properly. We have a form that is sent out, but the form is public. Well, which one of us is going to put down something negative that's going to go on that form because it can destroy a superintendent. It'll make the situation worse. I'm more worried that it will make him worse. To go back to Ed Whigham's idea of when you demote somebody, you've got to do it in such a way that the person's still got to function. So if you have a superintendent, maybe your criticism is not such that it's enough to terminate, see. But it's something that is correctable or should be corrected. Or at least I want to bring it up and 
have the other board members hear it, and we all discuss it out in the open. Open among board members, not to the public. And maybe I'm off base. Maybe I'm the only one that sees it as a problem which may mean that it is not a problem if nobody else sees it as a problem. But you can't do those things in public and do them properly. Because every one of those things that you do is going to weaken the superintendent. So every time you make a criticism like that, it's going to weaken the superintendent. Because it's done in public. If it's done in private, it can strengthen a superintendent. But if done in public, it's going to bring the superintendent - every criticism he gets is going to bring him down a notch because he's got in this instance forty or forty-five thousand employees out there, all looking in.

It is interesting to note that this example used Dr. Whigham's treatment of employees to illustrate Mr. Braddock's point about the Sunshine Law. Once again, his comments seem to reveal both a great deal of admiration and respect for Dr. Whigham, as well as a desire to emulate his leadership style. Additionally, this example further expands the range of issues related to fairness to the assessment of the superintendent.

Mr. Braddock's concern for the fair treatment of employees in public was also noted by Dr. Joseph Fernandez:

He was always very fair. He never ever put down staff in public which was one of the things that if they ever did, I used to get into arguments with them publicly... Holmes never ever in all the years that I saw him sitting on the board... I mean he would disagree with staff... but he never took staff to task. Never embarrassed them.

Mr. Braddock's position on the Sunshine Law also reflected the sense of injustice that he felt as an elected official. In a 1971 Miami Herald article, he remarked, "The way the law is being interpreted now, there is a presumption of guilt on the part of all elected officials... Elected officials should have the leeway to meet privately when they felt the public's need could be better served" (Miami Herald, 1971).

Here, Mr. Braddock provides an example of a situation where the Sunshine Laws can be assessed in terms of its fairness towards school board members and politicians in 
general. Mr. Braddock seems to be suggesting the Sunshine Laws unfairly limit elected officials ability to provide effective leadership.

Mr. Braddock refers to recent exceptions to the Sunshine Law and explains why this exemption is fair:

We got collective bargaining as an exception... Five years ago when Toby Simon was Tornillo's lawyer... we were going back and forth with Tornillo on collective bargaining - we were going to the Supreme Court. I had to call another Sunday night meeting. And we were meeting on Sunday night down there. We've got to instruct our attorney on what to do. We are taking our case to the Supreme Court. So we've got to instruct him. And who is sitting on the front row? Pat Tornillo and Toby Simon, his attorney. They heard everything we said. They knew our whole game plan. They knew the whole thing. We never heard Tornillo instruct his attorney or anything, see. We had to instruct our attorney in total public. So we lost! Now, we might have lost anyway, but there was no chance of winning. We had no chance of winning. We sent our attorney up there with his hands tied. No chance of winning.

Fairness as a variable of adherence to the law. Although Mr. Braddock did not agree with the Sunshine Laws in principle, he expected others to play fairly by the rules, as is evident in Dr. Fernandez' remarks:

The one thing that always struck me about Holmes, too, as you know in Florida under the Sunshine Law, the only executive session you can have is to give instructions to your negotiator-your labor negotiator-and whenever the board went astray or staff went astray in those executive sessions getting into a secondary item that might be related to it but not exactly clear, he would always call the question. He would always take people to task on that and stop the discussion right away. But he was very adamant about observing the Sunshine Law and following the rules and regulations.

This concern for playing fairly by the rules was also noted by Mrs. McAliley:

And his courtesy, his adherence to the rules of the game. Parliamentary procedure. General protocol in dealing with school members. Dealing with administrative people and members of the public. He was courteous. Gracious. Most of the time. He'd get ticked off and get a little bit sharp, but he generally followed the rules of parliamentary procedure and general rules of gentlemanliness and graciousness. Didn't very often offend someone unnecessarily. 
These examples provide another interpretation of fairness for this analysis. In his view, Mr. Braddock believed that laws, rules and regulations in the United States were established to ensure fair and courteous treatment of individuals. So, even though he did not agree with the Sunshine Laws, it appears that he respected them because of their intent.

Fairness as a variable of politics. And finally, even in his decision to retire from the school board and not run for re-election, Holmes Braddock proved himself to be a fair man when he announced this decision early:

I figured it would give anybody else who wanted to a chance to think about it and talk about it and see if they could raise the money and see if they could put an organization together and have time to do it. As opposed to now waiting until say June or July just before primary time, and then announcing that I'm not going to run. Then there wouldn't be anybody else. It takes about a year.

Fairness as a variable of state leadership. Mr. Braddock's comprehensive leadership role on the Florida School Board Association also pivoted on issues of fairness and equity. He referenced the division between rural and urban counties that existed as a result of reapportionment:

You had the small counties that are very small. Rural. Most of them small and rural. Most of them in the northern part of the state. Many of them in the Panhandle. So-called red-neck territory... And you've got southeast Florida that's all urban... Now I'm a Florida Cracker. I didn't fit the profile, so evidently I was able to bridge the gap there because we had a pretty tough division there. I didn't try and ram things down their throat. I was able to get some things passed that helped both sides, or whenever I had to do things that they didn't really like, evidently I was able to explain it to them where they accepted it whether or not they agreed with it. And on the other side, I was able to keep big counties in mind... We still had some thoughts of pre-reapportionment. See prior to 1962, Dade County only had three House members. The largest counties in the state had three. And there weren't that many, and so each county had one. Every county had one. And then some counties had two and there were some that had three. And there was Dade County, a huge county and we only had three. And a 
little county of a thousand had one, see... So reapportionment came about. And when reapportionment came, Dade County had twenty-one House members. From three to twenty-one, and some of those counties went from one to a county to one to every two counties, see. And so that caused - that was probably the genesis of all of this. The big counties hated little counties and everything. And they called it the Wool Hat Boys because the Wool Hat Boys had more clout than we did. Six or seven of those little counties that had one-fifth of the population of Dade had maybe six or seven votes and Dade County had three. So they could out-vote us all the time. So Dade County only got what they decided Dade County ought to have. We never had the votes to get anything. We always got what they decided they wanted to give us. So Dade County always hated them and of course they hated Dade County. Then when the reapportionment came it went so far the other way, and Christ now, they hated us now even worse! And then there were some of the big city people who said, God damn, the shoe's on the other, now we can go grind you into the dirt, see. So that made it even worse.

Perhaps Mr. Braddock's personal background contributed to his successful leadership at the state level. Having been raised in a rural county, he understood their issues, and having served in Miami-Dade County, he certainly understood urban issues. However, his comments suggest that reapportionment made statewide politics more equitable and fair in terms of representing the people. Thus, issues of fairness were again the underlying variables that influenced his leadership at this level.

Fairness as a variable of national leadership. A commitment to fair and equitable educational opportunities was also reflected in Mr. Braddock's defense of urban school districts and the needs of urban schoolchildren, while serving on the National School Boards Association and the Council of Great City Schools.

See when you get out of the south, whether you go north or west and get out of the big cities, you don't see any blacks... You go to the midwest and the west and the small towns, there aren't any blacks. They are all white... They are all lily white... Now that was a suburb, see. They weren't a unified school district as we are... Now the big city is different. The big cities in the north, they are almost all predominantly black. Washington, Atlanta, Memphis, Birmingham, Washington D.C., Columbus, Cinncinnati, Cleveland, and you've got all these cities. They're majority black. New York, certainly. Boston, Buffalo. They're all majority black... So, I was on the NSBA Board for six years. Most of those board 
members come from small towns. Many of them with no blacks. Some may have a half of dozen or something, but they don't even impose a separate type challenge. If they're poor, they just sort of blend in with the poor whites. You don't even have to address the issue differently... So six years on NSBA Board, I-there I wasn't trying so much bringing to them the black thing, it's an urban problem which includes blacks. In my so-called farewell speech to them... I came out very strong, but I pointed out to them that you've got to realize that most of the cities are poor. Most all cities are poor. Dade County is the same way. I think that we had to be one school system. Miami's poor. Out here, these areas aren't, but Miami's poor. And in most other states, Miami would be its own separate system. Pinecrest would have a system. Miami Shores would have its own system. But the cities are poor. Being poor in a city is different than being poor in a small town. I was poor in a small town, but I always had a garden. I raised chickens. And I was poor. I said, Poor in a city is different. We don't have any gardens. We don't have any place to go. I went fishing. I went hunting. I could go out in my backyard. We lived technically in the woods! Where my house was woods. I could shoot squirrels, which I did. I could shoot rabbits, which I did. I could shoot birds, which I did. I could go half a mile and go fishing. And I had a garden. So poor in a small town is so different. Poor in a big city is a different thing all together. I pointed out to them that when they see poverty, they see poverty at a different level. The kids in the city don't have any of that... I said, Then you add to that the fact that they're black. See, that's a whole new dimension. I said, Not only do they have to fight the battle of being hungry for many of them, they have to fight the battle of being black. Now whether they should have to fight that battle is not the issue. The issue is that they are black and that is a battle in a lot of places. So that's what I tried to get across to them and I hope I did in some instances effectively.

In his comprehensive leadership role at the national level, Mr. Braddock

continued to raise awareness of issues related to fair treatment of school children regardless of where they live. His comments point out the disparity in the allocation of resources and opportunities between rural, suburban and urban school districts. Here, Mr. Braddock expressed a global vision that addressed policy makers and administrators across the country.

As Executive Director of the Florida School Boards Association, Wayne Blanton had firsthand knowledge of Mr. Braddock's role at the national and state level: 
And he has advocated that (the needs of minorities) on a local level, a state level and very strongly on a national level because he understands that urban boards are not the same or urban districts are not the same as the majority of the school districts in the United States. And he was always trying to make sure that the other districts understood their unique needs and I think was very successful at it.

Dr. Joseph Fernandez also reflected on this concern for the unique needs of urban children:

And the real issue here was one of fear. You know, people are always afraid of the unknown and of course here keeping in mind this kind of quiet community. Miami was a small town in the sixties. This town here all of a sudden in 1960 is inundated, not that the city didn't have Hispanic centers and pockets before, which it did. You know the Windwood area for years and years was Puerto Rican. But the fact was that all of a sudden they had this huge implosion of people coming in. You know, in 1960. And then between ' 60 and ' 80 before the Mariel refugees came in, we had the influx of the Haitians. And then we had the Nicaraguan influx. And the district was constantly getting besieged by that. But the board, to its credit, and the administration, to its credit, recognized it wasn't these peoples fault that they were coming. The kids had to be educated. And they came in all different sizes and shapes and backgrounds and everything else... People like Holmes stood tall on this damn thing.

Fairness as a distinguishing variable of his comprehensive leadership role.

According to Dr. Joseph Fernandez, Mr. Braddock's incredible sense of fairness and justice has distinguished him in many ways:

Holmes Braddock is my Nelson Mandela in Dade County. Really! He really is in many ways. He was always, Holmes was always for the minority guy, person. He had a lot of empathy for minorities when it was not popular. You know, now of course it's politically incorrect to not be that way. He truly feels that way. It's in his bones. Which here's a Southern Baptist, and the guy has so much empathy over the plight of poor people and people of color. He understands the injustices they've gone through. He is my Nelson Mandela in Dade County. He really is.

As a whole, the variable of fairness in Mr. Braddock's perspective encompasses the broadest examples and interpretations, and appears to be the primary influence on his leadership. Further analysis of integrity and courage as other variables of his perspective 
illustrates the fact that an overriding concern for fair treatment of others was the underlying principle by which he operated.

Integrity

Integrity defined as "strict adherence to a standard of value or conduct" or as "personal honesty and independence" (Webster's II New Riverside Dictionary, 1984) was another variable that significantly influenced Mr. Braddock's career on the Miami-Dade County School Board. It was reflected in many of Mr. Braddock's actions and decisions, and was often remarked on by others.

Integrity as a personal quality. Former superintendents Octavio Visiedo and Alan Olkes spoke fondly of Mr. Braddock's incredible sense of integrity as a school board member:

Octavio Visiedo: He's a man of integrity.

Alan Olkes: One thing that you could always rely on with Holmes, as a school administrator, was that he was going to tell you whatever it was he believed in whether you liked it or not... But I think the people sensed that whether they agreed or disagreed, they were getting a representative that would always tell it like it was. They didn't have to worry that he would say one thing and then do something else. What you see with Holmes is what you get.

In this example, Mr. Braddock's integrity reflects both a standard of conduct as well as personal honesty and independence.

This same theme was reflected in a personal note from former school board employee Genevieve Yarnold. She wrote in 1973, "It gives us renewed faith in our political system to see someone like yourself in public life, a person who makes up his mind about an issue and then doesn't change it with every change of the tide."

Again, this example of integrity points to Mr. Braddock's unwavering stance on a particular issue. 
Integrity as a variable of desegregation. Executive Director of the United

Teachers of Dade, Pat Tornillo, remarked about Mr. Braddock's unpopular stands on the issues:

I think basically, what sets Holmes Braddock apart from not just school board members but people in general, is his tenacity and his persistence and his ability not to succumb to any pressure, to change his mind on issues. I have seen, time and time again, Holmes Braddock make a decision as a school board member which was not popular with the public. And as a result, there are many people who advised him not to do that because it would cost him votes in the next election and I have never known Holmes Braddock to succumb to that kind of thinking. And in fact, his general response to anything like that would be, The citizens of Dade County elected me to serve on the Dade School Board. I am going to serve in the best manner in which I know. If they don't like the decisions I make, they don't have to vote for me the next time... And so he consistently took that position and I think that most of the voters, while they may not have agreed with some of his decisions going back to 1960 when he voted to desegregate the Dade County Public Schools which was an extremely difficult and emotional issue at that time, that most voters respected him for being able to make a decision that he felt was in the best interests of the citizens and the children of Dade County even if they did not. Even if they disagreed with what that decision was. And I think that's why he was returned to office for now the longest serving probably, school board member in the nation. Certainly in Florida.

Here, Mr. Tornillo defines Mr. Braddock's integrity in terms of his tenacious adherence to a particular position. Desegregation was used in this particular example of Mr. Braddock's integrity.

Integrity on the issue of desegregation was also noted in Mr. Braddock's personal effects. In these personal notes, integrity was defined in terms of "doing the right thing" even when no one supported it. In 1970, attorney Donald Blackburn wrote, "[I am] proud that there are men in public service willing to express the truth in the face of popular opposition." 
A thank you letter from constituent Francis Scheffsky commended Mr. Braddock for, "The intestinal fortitude to speak out and tell it like it is... [and for] taking the stand for right in the face of what seems to be political annihilation in a bigoted community when it comes to Civil Rights."

Local black leader, Dr. William A. Chapman, Jr. also noted Mr. Braddock's integrity on the desegregation issue. In his letter, Dr. Chapman shared his personal belief that Mr. Braddock's position was the right one and would be proven right in the future. He wrote, "My dear Mr. Braddock, it did indeed take a man of strong convictions and courage to take the stand which you took in the school bussing issue. I can appreciate the sacrifices called upon you and your business because of this stand, however, those who criticize you now will see things differently on another day."

All of these comments refer to Mr. Braddock's integrity in terms of his willingness to tell the truth and take a courageous stand. These comments point to the interplay between the variables of honesty, integrity and courage. Additionally, Dr. Chapman's comments reflect Mr. Braddock's vision, which has been noted as a contributor to his effective leadership, and to the personal costs that he experienced as a result of his actions. These were also noted earlier in this analysis.

Integrity as a variable of equitable treatment of students. A 1970 Miami Herald editorial praised Mr. Braddock's unwavering commitment to justice and equal educational opportunities for all students. In the article entitled, "Mr. Braddock's Lump of Truth," it was the opinion of the Herald that Mr. Braddock's integrity was derived, "From conviction, from belief in serving the public rather than merely self, from the 
moral focus that right and wrong need not always overlap and blur and leave a man floundering for direction" (Miami Herald, 1970).

Integrity as a variable of politics. This integrity has characterized $\mathrm{Mr}$.

Braddock's entire career. During his last re-election campaign, Mr. Braddock hired an advertising firm to help with public relations and promotional activities. He recalled:

They wanted me to go, do a little thing where you tell them - in the black community you would say this because that's what the black community is interested in. I had, in my committee, had blacks, Hispanics, Anglos, males, females. It was a mixture. And they'd want me to say, Well you know the black community is interested in this. Now this is what you ought to stress. Now when you go into the Hispanic community, this is what you ought to stress. And that is not what I did. In other words, my manager said, No, Holmes has been elected 34 years his way, saying the same thing in every community. And I don't think you should change. And all the rest of them on the committee said, You do what you want to do. This is how if we were doing this, this is what we would do. We think you ought to sell what this community wants to hear and what that community is interested in. And I just said, I' $m$ in the habit of saying the same thing in every community.

This example of Mr. Braddock's integrity also reflects his disregard for the political implications of his decisions that has been noted throughout this analysis.

Integrity as a variable of public policy. Mr. Braddock's personal integrity was

reflected in his position on policy-making and administration:

Policy was policy, see. If you are going to set policy... in a sense this is going to come out wrong - you've almost got to be above the fray. You can't be down there in it and set policy, because then you become an administrator and you start looking at things from the administrative point of view. That's good to understand that. But policy has to be set in a different environment with a different agenda.

Perhaps it is this ability to rise above the situation and view the issues objectively that enabled Mr. Braddock to make decisions with integrity. It is this deep understanding 
of his role as a policy maker that guided his actions and distinguished his service on the board.

Wayne Blanton also noted Mr. Braddock's sense of integrity in relation to policy and administration. He remarked:

Holmes understands the difference between policy and administration. Understanding that you can change a district substantially by the way you govern and you can also change the district by the way you administer. Holmes understands that the role of the board is to govern and then let the staff administer That's what makes him such a good school board member because many times there's a gray area there or people come into their elected jobs not understanding that and they think that they're there to administer as well as to be the policy people. And Holmes has always understood that difference so that's made him extremely effective over the years. He doesn't try and run the system on a day to day basis. He's always trying to improve it through a broad policy base.

This theme of policy versus administration was repeated in all of the interviews.

Alan Olkes and Octavio Visiedo each remarked:

Alan Olkes: Holmes was always very clear in drawing a clear line in the sand of what was policy and what was administration. And he would remind superintendents of this. He would remind board members of this continuously. And I heard him when the new board came on, he tried to remind them a number of times until they finally said they didn't want to hear it anymore.

Octavio Visiedo: I think the effectiveness of any public institution depends on having a clear line of demarcation between policy and administration. The whole purpose of having an administration is to bring professional people to make professional decisions that have been generated from public policy positions. And they are two different things. There may be a public policy position on curriculum that can be implemented either effectively or ineffectively. That's the role of the professional person. What's happened in government, beyond just the school board - you see it in county government, you see in the city government is we moved to this quote single member district or this voting rights act where you had that single member approach. What has happened is that line has blurred and the policy makers are pretending to be managers and quite frankly, they are selecting managers who don't want to lead, that basically view themselves as caretakers. Clearly that's the case with the school system.

As a policymaker, Mr. Braddock understood his role. This is evident in his earlier remarks. Both he and Mr. Visiedo seem to understand that the effect of this "blurring" of 
roles has led to little leadership and ineffective school stewardship. Thus, Mr.

Braddock's insistent concern to ensure the integrity of the school board member's role was based on his understanding of effective leadership.

Dr. Fernandez and Mr. Tornillo also commented on Mr. Braddock's integrity as a school board member:

Joseph Fernandez: $\mathrm{He}$ - all the years that I've known him while being on senior staff and also as superintendent - he never once crossed over the line into administration which you can't say for too many board members. He knew the difference between who the policy makers where and who were the implementers of the policy. Now, he'd take you to task if you didn't implement the policy the board voted on whether he agreed with it or not. So he was always adamant about that...In all my years there, I can never recall Holmes ever coming to me and asking me for any kind of favor you know in terms of looking someone over for a position or something of that nature. You can't say that about all the board members. It's a political job in many ways and the politics of education is very real. You just have to know where to draw the line if you're going to be true to yourself and true to the system. But Holmes to me like I said, is the epitome of a board member. He would remember, even though I got appointed superintendent on the first ballot unanimously, and I think I'm on very good terms with Holmes, he always liked me as an administrator-liked my work-even then he insisted that the district do a search, a national search. Of course he was voted down and then he was part of the unanimous vote to give me the superintendent's job.

Pat Tornillo: Holmes always took the position that it was the superintendent's job to run the school system. It was the school board's job to make policy and if they didn't like the way he implemented that policy, then they should get rid of him. He is very strong on the separation of policy and the implementation of policy. He's voiced his opinion on that on TV and to the consternation of a number of other board members.

Integrity as a variable of leadership. Integrity was also reflected in $\mathrm{Mr}$.

Braddock's decision to decline the board chairmanship on a particular occasion:

Another time I turned it down because I had already committed to one other board member. And he couldn't get the votes. It was three-three-one tie, and so one of the people on the other three wanted to know if I would take it. We called a recess. We couldn't get off a three-three-one, so we didn't have any chair. And they asked if I would take it. That would make it four-two-one right there, see. I said no I was committed to him so I wouldn't back off from him there. So 

anyway, the guy who had it before, they gave it back to him although they really
didn't want, he really didn't have the votes to get it.

More recently, integrity could be identified as a factor in Mr. Braddock's decision to decline a nomination for the vice chairmanship. After a lengthy vote to elect a chair and the subsequent selection of Dr. Solomon Stinson, Mrs. Manty Morse nominated Mr. Braddock for selection as the vice chairman. He declined and stated for the Herald, "It wasn't a situation I'd want to be vice chairman. I think this is one time I don't need to say anything else" (Miami Herald, 1998).

Integrity was a quality of leadership also identified by Pat Tornillo. His remarks seemed to describe Mr. Braddock:

I think there are some basic qualities that make a good leader. I think some of them are to keep your word. When you make a commitment that you support something, that you keep it. And that regardless of any pressure that you receive, you don't change your opinion or your view.

Mr. Tornillo seems to suggest that in many instances leaders can be influenced by others. He states that true leadership requires integrity and strength of convictions.

Wayne Blanton felt that integrity was a key element in Mr. Braddock's successes as a school board member:

The fact that Holmes does the right thing... he's assumed a leadership role and he took those heavy decisions on his shoulders and pushed the things that many people were unwilling to push... You go back all those years and he did the kind of things that nobody else would do and he's willing to address the issues that other people shy away from. Whether it be what's right for Hispanic kids or what's right for Black kids or what's right for poor kids or the fact that you shouldn't be recruiting at the high school level when that controversy hit a few years ago. The whole gamut of controversial issues, you never have to worry about where Holmes stands. You know where he's going to stand. He's going to do his homework and he's going to make the right decision. He might not win them all, but if in his mind and in the mind of the people that even are against him, they will always understand that he's made a selected judgment based on his best information and his vast knowledge of a variety of different areas. 
Here again, integrity is defined as upholding a standard. And in this instance Mr. Braddock's integrity is defined in terms of ensuring fair treatment of others, a variable previously discussed.

Integrity as a variable of fair treatment of others. Mr. Braddock's incredible sense of loyalty and commitment was further evidence of his personal integrity as illustrated by Mr. Visiedo's recollection:

I just think that if there was a drawback to Holmes, it's that same precise loyalty and honesty and courage. At times, in my opinion, he didn't give himself the opportunity to change for things that he should have changed. I'll give you one point to simply make - you know, I mean we've been talking honestly about all the great things about Holmes, I think that he got himself-it was after I left-got involved in this thing about naming schools after board members. He felt so compelled to support that effort because other board members-even though it's a different board -or maybe it wasn't, maybe it was the same board-had supported him when he got his name. He felt so compelled to do that, that you know given the different circumstances and the different climate and everything else, it would have been perfectly okay for him to basically say, I'm not going to do that. But his sense of loyalty was such, that he wouldn't change his mind... But that was Holmes' integrity.

What is interesting in this observation is the fact that Mr. Braddock's integrity seems tied to a sense of loyalty toward others. However, looked at in a different light, Mr. Braddock's "loyalty" to those who voted to name a school after him, could also be interpreted from the perspective of fairness. His integrity on this issue was simply a matter of fairly supporting those who had supported him.

A Miami New Times article on the same subject of school naming stated that, "Braddock says he believes, just as he did in 1996, that Krop's service on the school board qualifies him for the recognition... What the public has to say generally has no 
bearing on how I vote, unless they offer me some new information"(Miami New Times, 1998).

These comments further illustrate Mr. Braddock's statements earlier in the text when he discusses the concept of firmness. That is, his position once taken can only be swayed by a compelling presentation of facts. This too, repeats earlier observations of his objectivity in making decisions.

Integrity on the issues. A personal sense of integrity was the impetus behind Mr. Braddock's efforts to stop a board action that he believed was wrong. He recalled:

At the time, I didn't think that I was going to stop it. I just thought I was going lay this clean and get my say. And I've had my say and what they do they've got a right to do. But it was so strong, that they didn't do it.

This point illustrates the fact that sometimes integrity on the issues is so compelling that it can sway others to do the right thing.

Mrs. McAliley also commented about Mr. Braddock's integrity on the issues:

So often in politics people try and dodge the issues and he never has that I've known of. You have to admire that, even when you disagree with him, which as I mentioned we did disagree on some things. But he always just had the strength of character to say what he thought. And I think he is very respected for that.

This statement reflects a cognizance of the political aspects of public service and Mr. Braddock's apparent disregard of those considerations. Mrs. McAliley also suggests that Mr. Braddock's integrity in this area has earned him respect and admiration, which may have contributed to his longevity on the board.

Dr. Fernandez' perspective concurred that Mr. Braddock was not unduly hindered by the influence of his colleagues either:

And he wasn't always the most popular board member I've got to tell you, even with your fellow board members. But Holmes, you know, he let that go. It didn't 
bother him. What bothered him more than anything else was did he think he was doing the right thing for the kids. I truly believe that he believed he was every single time. Even though I may have disagreed with him sometimes, but I tell you more often than not, in the long run when you go back and revisit things, he was proven right... Holmes really had the ability of keeping the board firmly at the plate in terms of the issues. He was not afraid of criticizing board members. I mean when they were doing something that he felt was wrong, he was not afraid of taking them on. Even people he considered his allies, you know. He was really a one-man show. He worked with people, but at the same time he did it up to a point. He did it up to the point where he felt it wasn't right and then he, you know. And he was not above making deals either, you know that's part of the politics of the board. Sometimes you have to make a deal to get the necessary votes for something that you feel is very important. As long as you're not selling your soul. And Holmes never sold his soul.

\section{Courage}

The third variable of $\mathrm{Mr}$. Braddock's perspective presented for analysis is related to courage. Throughout the secondary interviews, and a review of news articles, personal letters and notes, Mr. Braddock was often cast as a courageous individual. Broadly this data describes courage as a fearless pursuit of a goal. Whether the issue was desegregation, attendance boundaries or school busing, Mr. Braddock often took an unpopular and courageous position. As has been illustrated previously, his decisions were based upon an objective consideration of the facts in the context of doing what was fair for all students. Once decided, Mr. Braddock was fearless in promoting his position. Thus, this personal quality of courage was identified as a variable of his perspective and an influence on his policy positions.

Courage as a personal quality. When asked about this description of himself, Mr. Braddock responded:

I never had a problem taking a stand on something. But I never took it because it was courageous, I just thought - I always did what I thought was right. I didn't worry about what the consequences were. I didn't think anybody was going to kill me - I mean I've had threats, yeah. But I mean I never took it for those 
reasons. Now, other people maybe would find it difficulty taking those stands which were not difficult for me... In other words, those things that other people call courage in me was to them because they couldn't do it, but it never... it didn't take a lot of courage... But I won't walk away from one on a policy that I think probably should be there. And I never worried about whether people cared about
the decision or not.

In Mr. Braddock's opinion, courage was not a factor in his leadership. Rather, a compelling need to ensure fairness and the integrity of this position led him to make the decisions that he did. However, as seen from another's perspective, his actions did require courage.

Courage as a variable of leadership. Courage was a characteristic that Octavio

Visiedo viewed as necessary for effective leadership.

If you have no courage, you can't be a leader. A leader is going to be somebody who basically said, I really believe in this thing. I know I'm not going to get any support. I genuinely think this is the best thing to do and I'm going to do it because I've got to wake up in the morning and look at myself in the mirror. And I've got the courage to do it. I think if you are courageous, honesty and integrity-I think you don't separate them because it takes a certain person, a certain kind of individual to be courageous and I don't mean somebody that just goes off half-cocked or something. I'm talking about after careful analysis and looking at the numbers and saying, It ain't there for me, but I genuinely believe in this thing so I've got to do it. That's not shooting from the hip. That's having a conviction and believing in something and doing it. I think if you have that, whether it be at the board level or the superintendent level or the principal level, I think you just separate yourself from $95 \%$ of the universe. And there are not a lot of people who have courage. There are just not a lot of people that are willing to put it all on the line and say, I' $m$ willing to do that and if it costs me my job or if it costs me my position, so be it. But I believe in it so much that I' $m$ going to do that. And that is what right now there is no-public officials are not doing the courageous things. They're counting votes. O.K., I think I've got this one. Or cutting a deal in order to-I used to say you know leadership is not a popularity contest. If you are going to lead, you better get ready to have people mad at you, upset, you know, but you've got to lead. And so, courage would be the word.

Mr. Visiedo clearly views courage in Mr. Braddock's terms. Again, the idea that courage is really the demonstration of the strength of your principles defines Mr. 
Braddock's concept of leadership. It is also interesting to note that $\mathrm{Mr}$. Visiedo refers to a lack of leadership by today's elected officials acknowledging their fear of the political ramifications that may come from courageous actions.

Courage as a variable of desegregation. The desegregation of the Miami-Dade County Public Schools has already been established as a tenuous time for the community. During this time, Mr. Braddock's strong and unwavering position on the issue was cited as courageous by many. Octavio Visiedo described Mr. Braddock's role during that time:

Incredible courage! Alan already alluded to it. We did the desegregation. I didn't live that, but I can tell you that, I mean that was a personal-he was in personal jeopardy, there. I mean that was not play stuff, or somebody saying, I'm going to write you a nasty letter. Personal jeopardy.

Mr. Braddock's own children recalled the personal jeopardy that the family faced as a result of their father's stand on desegregation. In a recent Miami Herald article, Mr. Braddock's daughter Rebecca Nimmer stated, "I remember when they put burning crosses on our lawn" (Miami Herald, 1999).

Son, George Braddock, also remembered, "We've had more than a few death threats during desegregation" (Miami Herald, 1999).

Evidence of his courage was also found in an examination of Mr. Braddock's personal effects. Numerous letters from detractors vilifying his stance on desegregation were found in these papers. One such letter written by Miss Helen Douglas states, "The Klan will rise again... Your marked for extermination G. Holmes Braddock... You should be stretched on a meat rack and a slow fire ignited under you... The National Socialist Party is out to get the likes of you." 
Others called Mr. Braddock "a communist rat," "a stinking liberal," and included such things as pictures of the deceased Nikita Khrushchev labeled with Mr. Braddock's name. All of these examples further illustrate the emotional intensity of the public's opposition of his position. Faced with such tangible evidence of their opposition, many public officials would not have stood firm on the issue. However, Mr. Braddock's integrity on this issue caused many to view him as courageous.

In the face of the emotionalism of the time, Mr. Braddock remained steadfast on the desegregation issue. In a speech where Mr. Braddock exhorted "lying Southerners" for their hypocritical stance on cross-busing, he received public praise from across the country. Mrs. Hugh Russell from Atlanta wrote, "Many thanks for your brave and honest statement. Every Southerner knows the things you said are true, but few admit it, and rare is the public official who has the courage to say the things you said."

Joe Lance from Plant City wrote, "I like the freedom, the spirit and the prosperity of this land of ours and I hope it lasts a thousand years. This can only be when public officials have the character in the first place and the courage in the second, to know and speak the truth."

From these words, a new definition of integrity is suggested. Mr. Lance's use of the word character seems to be interchangeable with integrity. And again, the concept that integrity or character is intertwined with courage is also suggested here.

In a 1969 Miami News article, local Black activist, Theodore Gibson stated, "I really admire the man [Mr. Braddock] and it made my heart glad when he saw the light and had the guts to stand up and say this is what's right. Now let's do it" (Miami News, 1969) 
Janet McAliley also remembered Mr. Braddock's position on desegregation:

He was steadfast and he spoke out fearlessly. And I've always admired that very much in him. Sometimes we had strong disagreements when I was on the school board, but it wasn't about desegregation or race issues. There were other issues we differed on, but I always respected him because even when we disagreed he was never secretive about his beliefs. He was always very straightforward and would speak out no matter who was on the other side. And I think that's very courageous and he is a person of strong character.

Like Mr. Lance, Mrs. McAliley chooses the word character to describe Mr.

Braddock's integrity. Again, these two variables seem to be synergistically connected.

Dr. Joseph Fernandez comments reflect a definition of courage as standing in the face of difficult odds:

I mean Holmes was probably in my estimation one of the most courageous board members during the early days of desegregation. When the community generally was opposed to it, he put his political life on the line many times and voted in favor of the faculty integration and the student integration. And he just overall, I can't think of a moment. He was very courageous in a lot of the steps that he took where he was not always on the popular side of an issue. And as things would prove out later, he was generally right... But he was a very, very brave board member. Very courageous board member.

Courage as a variable of local leadership. Courage on the desegregation issue was most often noted by the newspapers in their support of his candidacy for re-election. One unidentified article stated it this way, "If one person can be considered the rudder who has safely brought Dade's school system through the emotional and political storms of recent time, it is Mr. Braddock. He has been unflappable... It took courage to stand firm. Mr. Braddock had that courage."

Other articles referenced Mr. Braddock's courage in these words, "Holmes Braddock, chairman of the Dade School Board, has persisted in following the law of the land and the orders of the Federal Courts in desegregation of the public school system. 
For this, Mr. Braddock has been vilified from Homestead to Carol City... A weak man would have quit long ago. Mr. Braddock qualified on Tuesday to seek another term as a member of the school board. That proves he's courageous, too" (Miami News, 1970). And in another, "Holmes Braddock, who has been chairman before, is one of the most courageous members ever to serve on the board... Braddock ought to be the first choice to lead the board again when a new chairman is chosen Nov. 22" (Miami News, 1977).

In each of these excerpts, Mr. Braddock's courage is expressed by his firmness on the issue. It was the integrity of his actions that defined his courage.

Courage as a variable of the fair treatment of others. Mr. Braddock's courage was also noted in other contexts where he took a stand for what he believed in. Octavio Visiedo shared a personal incident:

I think, the classic story about Holmes' courage. I don't think anything can top this. Not even desegregation. When I was selected to be superintendent, and I don't know if you recall all the turmoil, but that auditorium was packed. The black community was all there. All this turmoil and the chairman was Bill Turner at that time, had started basically allowing board members to speak their mind about who they were going to vote for for superintendent. He started on his left. There were four votes already there for me to be superintendent. They had declared it. We're going to vote for Mr. Visiedo and that's it. Holmes was the fifth. He was up for election. We were at at-large elections so the black community was an integral, a critical part of his selection as a board member. He already knew I had the votes. Matter of fact, next to him was going to be another board member that had already committed, although she hadn't said it publicly to me. So I had five votes already. He said out loud that he was still going to vote for me. He could have easily said to me, OV, I know you're safe. I would have been there for you. And I wouldn't have held that against him. But he had given me his word, and he did it. Now there was a huge thing, they tried to unseat him and do all these things. He still won, but the point is, if that's not a measure of a man's integrity, courage and loyalty and commitment, nothing is. I would submit to you that probably on the board today, with maybe the exception of him and possibly Ms. Kaplan, all of them would have folded under that circumstance. 
Mr. Visiedo relates this unique and personal incident to illustrate Mr. Braddock's courage as a politician. He acknowledges that political considerations were a factor in the situational context of this event, but that Mr. Braddock's integrity compelled him to hold to his convictions in a politically courageous manner.

Courage as a distinguishing variable. Several secondary interviewees saw Mr. Braddock's courage as being the hallmark of his legacy. According to Mr. Visiedo:

You know, I guess if - and I'm sort of taking a step back - if you're trying to sort of paint an objective picture of a guy who for all practical purposes, is an institution, in today's climate he will not be acknowledged as an institution. They'll give him lip service, but they won't acknowledge it. I think that in itself is a testament of his greatness. To sustain such an assault of generations. To sustain a shift of administrative climates. To sustain all of the social changes that have evolved during the period of his tenure is just such a testimony of his strength, inner strength, and going back to that word-that courage. And see, unlike a lot of politicians, Holmes campaigned hard. He did it hard. He wanted to be on the board, but he didn't just want to get elected. With Holmes there's a difference. Holmes wanted to be on the board. He did a lot of things that would fly in the face of somebody who wants to get elected and so the two - that's what sets him apart from other people. A lot of the other board members wanted to be elected. They wanted to be elected. He just wanted to be on the board. He wanted to do policy for public schools. He believed in it. So there's a real difference there. If you looked, if you just subjectively looked at some of the things that Holmes did you would have said, This guy's suicidal! You know, politically suicidal. Because he went upstream on the majority of the major issues. So that's a core, fundamental difference between Holmes and anybody else.

In this statement, Mr. Visiedo illustrates the significance of Mr. Braddock's

leadership and school board service during his thirty-eight year career. He acknowledges the external forces of the situational context during this tenure and seems to attribute Mr.

Braddock's successful leadership to his integrity and courage.

Wayne Blanton also commented on leadership. He noted:

Leaders have to take tough positions and it takes courage to be a leader. And Holmes is blessed with courage and has a lot of it because he has taken on a lot of 
tough decisions. And you put courage with doing what's right and would it be personal or political, and Holmes is probably the most effective leader in the
school board ranks in the history of Florida.

Mrs. McAliley closed our interview with these thoughts:

He will always - anybody in politics who has stuck their neck out on things is going to have their detractors-but I don't think that his will be very significant disagreed with him many of them. Most people, even though they may have

It is apparent from the data, that courage was a resonant theme in Mr. Braddock's perspective. However, it must be noted that courage was significant because it was tied to the other variables of fairness and integrity. As indicated, Mr. Braddock's courage was essentially a reflection of his strong convictions, or integrity, on issues of fairness. Honesty

The final personal variable that was identified in Mr. Braddock's perspective on his school board career was honesty. As defined by Webster, an honest person is "truthful, genuine, frank, sincere, and without affectation" (Webster's II New Riverside Dictionary, 1984). And while not explicit in the preceding analysis, this variable was often implied by Mr. Braddock's actions and words.

Honesty as a variable of leadership. Specifically, honesty was discussed by Dr. Fernandez, Pat Tornillo, and Alan Olkes as a key component of effective leadership:

Joseph Fernandez: First of all, honesty is very critical. I think that you have to be honest to yourself and to the system in the sense that you stand for the things you feel are right. You may be wrong! But you still stand for the things you feel are right. You gather the data. Analyze the data. Based on good solid data, you make decisions and you try to convince people as to why these are the right decisions.

Pat Tornillo: You are honest about what you believe in even though that may be contrary to what they believe in.

Alan Olkes: Honesty. Honesty and integrity. Those two go together. 
From these comments and the preceding analysis, honesty can be viewed as an essential quality of leadership whereby objective assessment and a truthful nature can compel a person to act with integrity.

Janet McAliley also noted honesty as being a key element of an effective school board member:

I think first of all we should be very much the advocates of children. And they have to be honest, because the public so loses confidence in the institution that they operate if they perceive that they are some how involved in doing things for their own personal gain or favoring their friends or other people unjustifiably. The public loses confidence in the institution-in this case the school systemand they are not as supportive either on referendums that are needed for funding of different things in the school district or they are not supportive by enrolling their own children in public schools.

Here, Mrs. McAliley uses honesty in the context of integrity. She believes that a school board member should have enough integrity to be honest and base decisions in the public interest.

Honesty as a personal quality. When describing Mr. Braddock and his career, honesty and forthrightness on the issues were the first words used by Alan Olkes and Octavio Visiedo:

Alan Olkes: Honest. Forthright. One thing that you could always rely on with Holmes, as a school administrator, was that he was going to tell you whatever it was he believed in whether you liked it or not. There were times when Holmes and I did not agree on things, and ah, he was always willing to listen to your other side, but he made it very clear that he felt strongly about certain things.

Octavio Visiedo: Ah, my impression of him was very similar to Alan's. Incredible forthrightness at the expense of his own-creating problems for himself which is something that I shared and was sort of my practice too.

On the issue of school desegregation, a Miami Herald article said of Mr.

Braddock, "He took no polls, tested no winds, and instead relied only on old-fashioned truth when he spoke. It was an exercise in that vanishing quality of responsible political 
leadership, rather than the more frequent scramble of the politician to guess the direction of the crowd and run to be in front" (Miami Herald, 1970).

This article acknowledges the importance of honesty in political leadership and describes Mr. Braddock as an honest leader.

Another Herald article stated, "The voters should appreciate Mr. Braddock's candor and realism" (Miami Herald, 1970).

Mr. Braddock's personal letters also illustrate the significance of his honest position on the issues. In response to his public challenge of Governor Claude Kirk and his segregationist position, Mr. Braddock received mail from across the country. School Board President, Grace Bader, from the Hewlett-Woodmere Public Schools in New York wrote, "The straightforward, forthright and honest comments I read gave me real hope that these different problems were being competently handled by top-level Board people."

A telegram from local Black leader, Thelma Green, also intertwined honesty with those qualities already previously noted, "Honesty, integrity, courage and conviction spell G. Holmes Braddock. We love you all to victory.

In support of his re-election bid, the Herald acknowledged, "Mr. Braddock's record of forthrightness on controversial issues such as desegregation bespeaks his intellectual honesty" (Miami Herald, 1978).

In each of these excerpts, honesty was integrally tied to courage and conviction, other variables of his perspective. However, in the comments expressed by the Miami Herald, honesty is also tied to intellect. It seems that this attribute again reflects an 
objective and fair mind, another observation that was made of Mr. Braddock's decisionmaking.

Honesty as a variable of policy making. In later years, Mr. Braddock spoke out honestly on the issue of school overcrowding. No fan of complaining parents, he was quoted in the Miami Herald. "It's no secret that schools in the West Dade are overcrowded and that we have to build more. We just can't keep up with the rapid growth in that area. It takes time to build new schools. And people should have realized that before they moved in. All they had to do was look around and they could see there were no schools in their neighborhoods." (Miami Herald, 1978)

When asked about how he thought he would be remembered, Mr. Braddock noted:

I guess I like to think that people will think that I always tried to be fair and honest. I wasn't on the board for personal gain and all those kinds of things, see. I was fair and honest and did take a stand when I thought-in other words, I didn't take stands that were necessarily popular. I didn't take stands to be unpopular.

Perhaps honesty is the variable that best describes Mr. Braddock's objectivity. As such, it is this variable that interacted with his sense of fairness that allowed him to make the tough and courageous decisions that exemplified his integrity.

\section{Situational Context}

Unlike the preceding analysis of the variables of Mr. Braddock's perspective, the fifth variable, situational context, is not related to internal personal qualities. Rather, this variable was related to external factors of time and place.

Situational context as a variable of leadership. Throughout the interviews with Mr. Braddock, the situational context of the issue was referenced as being an important 
contributor to the success or failure of a decision or policy. Mr. Braddock shared his own belief about why certain people succeed at a certain time:

In the Methodist church-I happen to be a Methodist-we recognize that very few people have all of these attributes. And I don't know what your religion is, but Methodists change their ministers... We can recommend to what we call district superintendent. He tells the bishop what kind of person we'd like to have. Then, the conference will determine who that person fits that. For example, we may find out that we need to build a new church. And let's just say that the minister that we have is not a good fund raiser. He may be a good pastor, maybe a good administrator, but he can't raise money... We've got to build a new church. So we need a minister who can go out and raise money. Everybody can't do that. I'm a good example. So that in this instance, they would send someone to us who is really strong in raising money. He might be here two, three, four years to raise the money. That doesn't mean he won't preach and do the other things. His forte is going to be raising money. And quite often, after three or four years has come and he's worn out his welcome because that type of person can wear on some people. And so, and usually he realizes this and there's a conference. Now, the conference will move him some place else and move in here now someone who can go back to pastoring. Maybe he's good in the pulpit or maybe he's what we call a pastor who can call on the people and keep his flock happy and so forth. And those kind of things. So they recognize that very few people can do the fund raising, the pastoring, and the preaching. Some people can do two, but are not a good preacher from the pulpit. We can't have a person too long who can't preach. So in other words... he'll just move someplace else where they need the talents he has.

In this example, Mr. Braddock acknowledged the factors that contribute to

successful leadership and how those factors may change over time thereby causing a

change in leadership. Mr. Braddock went on to equate this example of situational context

in the church with situational context in the school system.

I think the superintendents are in the same thing in a sense. Sometimes you need a very strong educational leader at a given time. A real strong educational leader. Another time you might need someone who is a good strong organization person. Strong organization. And then you find out you may need somebody who can just inspire the troops so to speak. 
Mr. Braddock suggests that understanding the external forces at work within and outside the organization often dictates the leadership style that is needed in a superintendent.

In relation to his own career, Mr. Braddock saw the situational context as an influential external variable. He used his selection as chairman of the board to illustrate this point:

In '70, '69, I guess I was elected to chair in '69, we were just going through desegregation then. So that was a heavy hard time. That was probably without any question the hardest period of time the chair has ever served, that three or four year period there... but ' 69 until mid-seventies, that was probably the most difficult time and I was chair then. The board thought, I guess, that I was the one to have it during that period of time. In ' 82 some of the older board members came to me... The board had gotten kind of loosey-goosey,... meetings were starting late. A one $o$ 'clock meeting might get started at one twenty or one thirty. And the executive sessions that were called for ten might get started at ten thirty. And that's not my style. So they said, Holmes will you take the chairmanship. And I said, Well if you get the fourth vote, I'll take it. I'm not going to go out and get the fourth vote. I'll obviously vote for myself. If you get the fourth vote, I'll take it. And they said, Okay. So they went and got the fourth vote, so I took again. And that was mainly to bring structure back to the board... And I'm old-fashioned. If you call something for 1:00 it starts at 1:00. If you want to start at five after, why didn't you call it for five after one. If you want to start at 1:15, you call it for $1: 15$. So that was the reason then, and then one other time they wanted me to be chair and I-well one other time I kind of made a play for it and didn't have the votes. I thought I was probably the person for it at that time, but I didn't have the votes which means probably I wasn't the person for it.

In this example, Mr. Braddock further illustrates the influence of the situational context on determining the school board chairmanship. In the instance where the situation dictated the need for a structured person as chair, he prevailed. Whereas in another time and place, he did not.

Situational context as a variable of state leadership. The situational context was also referenced by Mr. Braddock as a key contributor to his success as president of the 
Florida School Boards Association. As previously noted in the analysis of fairness as a variable, Mr. Braddock was cited as being influential in mending the rift that once existed between the small and large districts in Florida:

Well, a lot of people give me credit for bringing the two sides together... To many of them, there are three kinds of people in Dade County. Yankees, Cubans and Jews. And not necessarily in that order. But to many of them that's who all lives in Dade County... And they aren't any of those. To them, they don't fit in any of those categories. They were always amazed that I could get elected down here being a Florida Cracker. How was it that I could come to Dade County and get elected and stay elected when I didn't fit any of those profiles. But I guessthe only thing that I could figure, the fact that I was from Dade County, but I was not brought up here and I understood what it was to live in a small county... I didn't fit the profile, so evidently I was able to bridge the gap there because we had a pretty tough division there... Well, anyway when I got the presidency, and again, maybe I was the person for the time. Again, I think sometimes now here's a person for the time. Maybe I was the person for the time in that job... But at that particular time the division was there. It seemed to come together under my term... People-both sides-people down here trusted me and the other big counties trusted me. And for some reason, I think because I was kind of one of them albeit forty years ago or fifty years ago, all those small county people seemed to trust me because I didn't fit the mold of a Dade County person, see... They seemed to like me, one. But of course you can like a lot of people. But I think the biggest thing was they did seem to trust me. Some of these guys from small counties-some of these counties across this country have got board members who have very little education. Not as many now as years ago, but I came on the school board thirty-seven years ago. You've got guys there with a ninth or tenth grade education on school boards from some of these little small town across the south or in the midwest or someplace. The real small towns. Farmers who went to high school and dropped out in the tenth grade and started working on the farm and now are school board members. I mean there were a lot of them around then. We still had some in Florida in those days, although not many. I doubt we have any around now. But years ago when I came on we still had some. But I've always been able to relate to people no matter what their station in life or whether they are rich or poor or black or white, I've always been able to relate to people like that... It was nothing I ever tried to cultivate or anything. And I happened to be president. You get in the chairs and you go through the chairs, I'm sure that when they asked me to get in the chair that they did not envision that two years later it would be my turn to be president that the situation would arise. So I don't know, I just think that I happened to be in that place at that time and had the personality or something to... Maybe I was the person for the time in that job. 
The situational context alluded to in this excerpt was clearly a function of time, place and person. Had Mr. Braddock served at a time when "bridging the gap" was not an issue, his leadership may not have been significant. Likewise, had another person ascended to the presidency at that time who did not have the ability to understand both sides, the results of negotiation may not have been successful.

Situational context as a variable of bilingual education. Mr. Braddock also recognized that the effects of the situational context contributed to his unsuccessful attempts to initiate certain policies. One example that he gave was related to the element of bilingual education and his unsuccessful attempt to create a bilingual school system for all children.

Another thing I tried to do, and I knew I would never get the votes but I tried, I wanted to make us a bilingual school system... Maybe if it were the best thing to happen, it would've happened.

In the transcripts relating this event, Mr. Braddock acknowledges the public opinion that was being expressed against this policy at the time. As was presented in the earlier discussion of bilingual education, the failure of this initiative was a result of the anti-Hispanic feelings held by many in the community.

Situational context as a variable of desegregation. Another example of the negative impact of the situational context on Mr. Braddock's successful leadership was his attempt to fully desegregate every school in Miami-Dade County. He recalls this example:

I wish we had desegregated every school in the county like they did in Hillsborough. I had the votes at one time and lost them. The court order came down and integrated or desegregated-I guess they're not quite the same - all but either 28 or 29 schools. There were 28 or 29 that were left either all white or all black, let's put it like that. All the rest of them had some measure of integration. 
After that, I got the board, at least the majority of the board, to approve directing the superintendent to draft a plan that would integrate every school in the county Leave no school all white or all black. And so staff did... And then we started having hearings around the county... Some of those that weren't in the desegregation just went ape. Absolutely wild! So, I think we were down to about a four-three, maybe five-two, I can't remember... I think had we done that then, I think we'd have been a far better off system... There would be no need for parents to move then. Moving wouldn't do them any good... That was probably the most disappointing thing that we didn't do.

But with Mr. Braddock's pragmatic approach, he viewed these failures in an optimistic light:

Of course sometimes bad things happen to cause good things to happen later on, see. And we all know that.

Situational context as a variable of policy making. Mr. Braddock's acute sense of the context of the situation has led him to take a backdoor approach on many recent school board issues. Recognizing the shift in power and influence on the board since the move to single member districts, he noted:

There may be some rear guard actions. I maybe slowed some things down that would have moved full speed ahead. I think sometimes no matter where you are-if you're in an elected position and a minority position, sometimes what you gain is what you stopped. In other words you got passed. Minority members in Congress get very few things passed. They stop some bad stuff from being passed or they slow it down or they get it watered down or changed or something. Certainly there's no question that I'm the minority member on the board for two reasons. One reason I'm a minority in that I'm an Anglo. I'm a minority in that I'm a liberal although the board may be more liberal than it will appear on paper... What have I gotten passed or done or been part of, I don't know. I think I've slowed down some. There's no question that I've slowed by bringing it to the attention of the board some of the board's expenditures. The question about bringing that up because Stinson got-and a bunch of them got mad at me, but it stopped it because it got out to the public. And there have been two or three things that I know which are not big things publicly but it did get some things stopped that would have been done if I hadn't exposed it and put such a strong stand on it. 
This example clearly articulates Mr. Braddock's recognition of his role on the school board during his final years of service. Further, he acknowledges an understanding of his leadership ability give the current board composition. Although obviously frustrated by this board and the conspiring situational factors that have worked against him, Mr. Braddock was not deterred from his obligations as a public official and continued to speak out honestly with integrity.

Situational context as a variable of faith. In other comments, Mr. Braddock clearly believed in God's role in selecting the right person for the right place at the right time. In reflecting on his role during the desegration movement in Dade County, he remarked:

I do think God puts people - certain people-in certain jobs, or in certain places at a certain time. That at a different time, would he fall on his face whereas one time, he doesn't? I think probably, I was put in the job of chairman at that time maybe for that reason. That's looking back.

He used a narrative to further illustrate his point:

I'll never forget, I was just out of the Army. And I was still in Jersey. I was married the first time and I was in Jersey with who was now my ex-wife. She had gone two years to Syracuse. And she had gone into service also. She was a chaplain's assistant in the WAC. So, I was hitchhiking, hitchhiking from New Jersey up to Syracuse.. And I hitchhiked up to Syracuse and put my application in and looked over the campus some, and I started hitchhiking back. We didn't have any money. I could have gotten a ticket, I guess. But hitchhiking then was safe... And I had my uniform on... And I came out of Syracuse and got down to a little town of Cortland. And I couldn't get a ride. All of a sudden a milk truck comes along and said he'd pick me up. It was one of those big long tanker milk trucks. And he starts down through the countryside out to a town called Green. I said holy God, did I make a dumb mistake here! He's taken me off the beaten path. I'll never get a ride. So he dumps me out in this little town of Green, New York. I'll never forget it. I was standing on the corner there, and there's nobody there! This is a town with nobody! And a car comes by though, and I'm hitchhiking now to Binghampton which is a pretty good size town... and so a guy picks me up and says he'll take me to Binghampton. He takes me to the main highway, and I get out of the car. And he's not out of sight and a car comes along and of 
screeches to a halt. I've got my thumb out, see. It was a family. There were two I said to New York or New Jersey, I can't remey said where are you going? And all the way down, 200 miles down, right remember. Anyway, they were going York City. Holy cow! So I took it downt down to the city. Right down to New Lord knew what he was doing. I got ther.. And I said to the lady, you know, the milk truck down into Green and Iendere actually quicker by taking that damn with a family that bought my lunch and up then getting one solid 200-mile ride king. And took me right to Penn Stationerything. They treated me like I was a home in no time. And so that's why I sanere I caught the train... And I was strange ways.

Perhaps Mr. Braddock's strong faith was a contributing factor of his leadership.

Perhaps his honesty and forthrightness were born from a religious foundation that valued the fair and equitable treatment of all people to the extent that he was continually compelled to make courageous decisions. Whatever the essence of Mr. Braddock's variables, it has been the force of these variables that have interacted with the situational context to determine his success or failure on the issues that constitute the elements of his perspective.

\section{Summary of the Chapter}

In summary, through the presentation and analysis of transcript data, five elements and five variables were identified as being reflective of Mr. Braddock's perspective on his school board career. These elements and variables constituted the key events and/or the underlying influences that were significant during his tenure.

\section{Elements of His Perspective}

Five key elements were identified in the data. Four of these, teacher professionalization, desegregation, bilingual education, and athletics were important policy issues during the thirty-eight years of Mr. Braddock's board service. These issues were significant not only because of Mr. Braddock's strong support for each, but also 
because of their broad historical implications. A fifth element, Mr. Braddock's comprehensive leadership role, was derived from his significant record of leadership at local, state, and national levels.

\section{Teacher Professionalization}

From the data, it was apparent that Mr. Braddock's strong support of teacher professionalization was originally derived from his mother's forty-one years of teaching experience. Having grown up as a schoolteacher's son, he was acutely aware of the need for unions and collective bargaining in order to ensure fair salaries, academic freedom and adequate facilities. This position of support was only deepened during his tenure. Desegregation

On the issue of desegregation, Mr. Braddock cited many influences in his transformation from a Southern Segregationist to a Desegregationist. Noting the graduate work of his ex-wife, the contradictions of segregation in the south, and the flagrant disregard for Federal Law as significant contributors to his strong position for the desegregation of the Miami-Dade County Public Schools, Mr. Braddock threw political considerations to the wind in his stand for what he believed was right.

\section{Bilingual Education}

Perhaps his most visionary but unsuccessful policy proposal, bilingual education was an element of Mr. Braddock's perspective that never came to fruition. His vision of a bilingual community that would ensure equal job opportunities and access for all residents received limited support when first proposed. Recently, this same initiative has been suggested again by others as part of the One Community One Goal initiative of Metro-Dade County Mayor, Alex Penelas 


\section{Athletics}

A more subtle element of his perspective, school athletics was nonetheless a very important policy issue for Mr. Braddock. From the need for increased financial support for school athletic programs to equal funding and access for female athletes, $\mathrm{Mr}$.

Braddock was a staunch supporter of athletics throughout his tenure Comprehensive Leadership Role

Mr. Braddock's comprehensive leadership role reveals the incredible depth of his leadership at the local, state, and national levels. Having held every major office for every major organization in the country, Mr. Braddock has demonstrated an acute ability to identify the issues, communicate effectively, and initiate those changes necessary to achieve ongoing support for public education. An analysis of this element also reveals the variables of his perspective.

For each of the five elements of Mr. Braddock's perspective, secondary interview data, media sources, and documents from his own personal effects substantiated the narrative and corroborated his recollections.

Variables of His Perspective

In addition to the five elements revealed in the analysis of the transcript data, five variables were also identified. Four of these variables, fairness, integrity, courage, and honesty were related to $\mathrm{Mr}$. Braddock's character and value system and it was apparent that the elements of Mr. Braddock's perspective were a direct reflection of his strong belief in these variables. In addition, the fifth variable of situational context illustrated the importance of time, place and person in determining the success or failure of a particular action. 


\section{Fairness}

Perhaps the most pervasive variable identified in the data, Mr. Braddock's concern for a fair and equitable treatment of individuals was reflected in essentially all of his school board policy and decision-making. Whether it was the need for a desegregated school system, or fair salaries for teachers, or equal opportunities for athletic participation or equal access to the economic community for non-Spanish speakers, Mr. Braddock's position continually pivoted on issues of equity and fair treatment for all Integrity

Integrity was a quality that was identified as a personal trait that Mr. Braddock admired in others and one that others suggested that he himself possessed. It was a trait that was especially valued in the realm of educational politics since children were the ultimate recipients of any board policy. Throughout the data, Mr. Braddock's integrity was the variable that enabled him to do the "right" thing instead of the "politically correct" thing.

Courage

Perhaps the most remarkable variable of Mr. Braddock's perspective was courage. While it often takes courage to stand up for what you believe in and to do the right thing, not many individuals have demonstrated the personal courage that Mr. Braddock demonstrated when he put himself, his family and his professional career on the line for school desegregation. As was noted in the historical evidence and in the review of the literature, this was a dangerous time for those individuals, like Mr. Braddock, who supported Civil Rights and school desegregation. 
Speaking the truth even when no one wanted to hear it was another hallmark of Mr. Braddock's board service. His "tell it like it is" approach to every issue reassured his constituents of his honesty, even if they did not agree with his position. According to $\mathrm{Mr}$. Braddock, this honesty and forthrightness was a major contributor to his longevity on the Miami-Dade County School Board.

\section{Situational Context}

The final variable of Mr. Braddock's perspective was related to the situational context of time and place. Mr. Braddock himself acknowledged the importance of time, place and person in determining the success or failure of his/her initiatives. Examples from the transcript data, such as Mr. Braddock's role in the desegregation of the MiamiDade County Public Schools and his role as President of the Florida School Boards Association illustrate the positive influence of being the right person for the right job at the right time. Other examples, such as Mr. Braddock's support for bilingual education and his defense against single member districts revealed the negative impact of time, person and place.

As with the analysis of the elements, secondary interview sources, newspaper articles, and personal notes validated the variables of Mr. Braddock's perspective and further enhanced his narrative. 


\section{CHAPTER V}

\section{CONCLUSIONS AND IMPLICATIONS}

In this final chapter, a general discussion of the study provides a context for conclusions that are derived from an assessment and evaluation of the research findings relative to the review of the literature. From this context, implications for future research are suggested.

\section{Discussion}

The purpose of this study was to describe and explain Mr. Braddock's perspective on his thirty-eight year school board career. Qualitative methods for data collection and analysis were selected in order to develop a comprehensive view of his school board service. In this manner, a comprehensive view of his career emerged.

Two key exploratory questions guided the study. They were as follows:

1. What elements constituted Mr. Braddock's perspective?

2. What variables influenced Mr. Braddock's perspective?

Using qualitative research practices, the key exploratory questions were the basis for the indepth interviews with Mr. Braddock and other secondary interview sources. Each of these interviews was recorded and transcribed for later analysis. Ad hoc methods of data analysis revealed several pervasive themes in the data. An organizational framework was developed to organize these themes and to guide the analysis.

In response to the first exploratory question, five elements of Mr. Braddock's perspective were identified in the data and presented. They were as follows: 
1. teacher professionalization

2. desegregation

3. bilingual education

4. athletics

5. comprehensive leadership role

In response to the second exploratory question, five variables of Mr. Braddock's perspective were also identified in the data and presented:

1. fairness

2. integrity

3. courage

4. honesty

5. situational context

The truthfulness and consistency of Mr. Braddock's perspective on his career was essential in order to ensure the validity of this study. Triangulation of the data was attained by presenting and analyzing segments of interview transcripts, media sources and Mr. Braddock's own personal effects related to his school board service.

The findings revealed that Mr. Braddock's comprehensive leadership role at the local, state, and national level was influenced by the variables of his perspective, i.e., fairness, integrity, honesty, courage, and situational context. Furthermore, his comprehensive leadership role was characterized by his support of issues such as teacher professionalization, desegregation, athletics, and bilingual education, which have been identified as the elements of his perspective. 
The inter-relationship of the elements and variables of Mr. Braddock's perspective is further illustrated in Table 1.

Table 1

Inter-relationship of the Elements and Variables of Mr. Braddock's Perspective

\begin{tabular}{|c|c|c|c|c|c|}
\hline $\begin{array}{l}\text { PROFESSIONAL } \\
\text { IZATION }\end{array}$ & bargaining & $\begin{array}{l}\text { Respect as } \\
\text { professional }\end{array}$ & $\begin{array}{l}\text { Support of } \\
\text { teachers' } \\
\text { rights }\end{array}$ & $\begin{array}{l}\text { Retelling of } \\
\text { teacher strike }\end{array}$ & $\begin{array}{c}\text { Role in strike } \\
\text { negotiations }\end{array}$ \\
\hline DESEGREGATION & $\begin{array}{c}\text { Equal } \\
\text { educational } \\
\text { opportunities }\end{array}$ & $\begin{array}{l}\text { Extremely } \\
\text { unpopular } \\
\text { decision }\end{array}$ & $\begin{array}{l}\text { Against } \\
\text { public } \\
\text { opinion }\end{array}$ & $\begin{array}{c}\text { "Lying } \\
\text { Southerners" }\end{array}$ & $\begin{array}{l}\text { Southern borm, } \\
\text { white man } \\
\text { espousing } \\
\text { desegregation }\end{array}$ \\
\hline $\begin{array}{l}\text { BILINGUAL } \\
\text { EDUCATION }\end{array}$ & $\begin{array}{l}\text { Equal access } \\
\text { to community } \\
\text { and } \\
\text { employment }\end{array}$ & $\begin{array}{l}\text { Unpopular } \\
\text { policy }\end{array}$ & $\begin{array}{c}\text { Brought } \\
\text { issue to } \\
\text { board for } \\
\text { consider- } \\
\text { ation } \\
\end{array}$ & $\begin{array}{l}\text { Refusal to } \\
\text { "stack" the } \\
\text { auditorium }\end{array}$ & $\begin{array}{l}\text { Strong anti- } \\
\text { Hispanic } \\
\text { feelings in the } \\
\text { community }\end{array}$ \\
\hline ATHLETICS & $\begin{array}{c}\text { Total } \\
\text { education of } \\
\text { the child }\end{array}$ & Fair play & $\begin{array}{l}\text { Persistence } \\
\text { to bring } \\
\text { about } \\
\text { change }\end{array}$ & $\begin{array}{l}\text { Illustrated the } \\
\text { true level of } \\
\text { district } \\
\text { support }\end{array}$ & $\begin{array}{l}\text { Strong support } \\
\text { of athletic } \\
\text { community }\end{array}$ \\
\hline $\begin{array}{l}\text { COMPREHENSIVE } \\
\text { LEADERSHIP } \\
\text { ROLE }\end{array}$ & $\begin{array}{c}\text { Local } \\
\text { State } \\
\text { National }\end{array}$ & $\begin{array}{l}\text { Objectivity } \\
\text { on issues }\end{array}$ & $\begin{array}{l}\text { Tough } \\
\text { issues }\end{array}$ & $\begin{array}{l}\text { "Tell it like } \\
\text { it is" }\end{array}$ & $\begin{array}{l}\text { Thirty-eight } \\
\text { years of } \\
\text { successful } \\
\text { leadership }\end{array}$ \\
\hline
\end{tabular}

From the table, the pervasive influence of the variables of Mr. Braddock's perspective can be seen in each of the elements of his perspective.

\section{Conclusions}

From the study, it can be concluded that Mr. Braddock's thirty-eight year tenure as a member of the Miami-Dade County School Board was exceptional for both the length and quality of service. As previously indicated, there is no other contemporary board member from a large urban school district in the country with years of service 
equal to Mr. Braddock's. Even more remarkable is the fact that Mr. Braddock's tenure exceeds the average term of service by five and one-half times (American School Board Journal, 1996). Therefore, not only is his longevity significant in itself, but the consistent impact of his leadership on school board policy from 1962 until 2000 is also relevant to this study.

Teacher Professionalization

Throughout this study, Mr. Braddock's leadership on the Miami-Dade County School Board was distinguished for his advocacy on key issues related to public education. The first element of his perspective, teacher professionalization, was the platform from which Mr. Braddock launched his successful career. An issue that reflected his own background as a teacher's son and the influence of fairness as a variable of his perspective, Mr. Braddock's support for teacher professionalization has evolved from a focus on salaries and bargaining rights to a focus on instructional quality and professional growth. This historical perspective was supported by the review of the literature, as were contemporary issues that are relevant for the profession today. Thus, the significance of this element of Mr. Braddock's perspective is grounded in its pervasive implications for public education policy making during his thirty-eight year tenure.

\section{Desegregation}

School desegregation was the second element of Mr. Braddock's perspective. Under his leadership, Miami-Dade County's public schools were reconfigured to comply with federal law and provide an integrated educational setting. A review of the literature on school desegregation provided an historical context for the issue, illustrated the 
positive effects on student achievement and postgraduate employment, and provided insights into the current debate over school desegregation. In addition, the presentation and analysis of the data for this element revealed the variables of Mr. Braddock's perspective that contributed to or influenced his position on the issue. Mr. Braddock's unwavering commitment to the fair treatment of all schoolchildren and his personal integrity on issues of importance gave him the courage to speak out honestly and forthrightly. Further, it was shown that although the community did not support school desegregation, Mr. Braddock's argument was so compelling that he was successfully able to transform the school district and integrate the schools. Therefore, issues related to school desegregation constituted a significant element of Mr. Braddock's perspective throughout his tenure and are significant to public education in general.

\section{Bilingual Education}

As a long time resident of the multicultural community of Miami, Mr. Braddock believed that bilingual education offered an opportunity for all students in the school system to acquire an important skill that would be necessary for employment. $\mathrm{Mr}$. Braddock saw the potential of such an initiative and courageously worked to promote a policy that would establish dual language programs in every school in the district. Although, Mr. Braddock's support of this initiative stemmed from the influence of the variable of fairness, as previously noted the situational context was not conducive to the success of this initiative and it did not succeed. Recent efforts to revisit this initiative and a review of the literature that demonstrates the positive academic benefits, as well as the economic benefits of bilingual education programs, establish this element as a significant school board policy issue. 


\section{Athletics}

School athletics was also found to be a significant element of Mr. Braddock's perspective. As discussed in the review of the literature, issues related to the viability of athletics as part of the school curriculum, the financial support of athletic programs, and students' access and participation in these sport programs were all aspects of this element during Mr. Braddock's career. And as a proponent of athletic programs in Miami-Dade County, Mr. Braddock advocated for fair play, equal access and increased financial support. Again, this position reflected the influence of fairness as a variable of $\mathrm{Mr}$. Braddock's perspective and provided an explanation for his support of these programs. Comprehensive Leadership Role

Mr. Braddock's comprehensive leadership role can be viewed as both an element of his perspective and as a result of the influence of the variables of his perspective on his school board service. A review of his vitae illustrates his record of leadership at local, state, and national levels. A review of significant policy issues for Miami-Dade County Public Schools illustrates his record of leadership in this arena as well. However, it was the review of the literature on leadership that revealed the influence that the variables of his perspective had on his comprehensive leadership role. In the data analysis, $\mathrm{Mr}$. Braddock's leadership was identified as stemming from a commitment to fairness, personal integrity, honesty and courage. These personal beliefs or attributes were identified as four of the variables of his perspective. These qualities of character were assessed in the context of a review of the literature on Trait Leadership Theory. This review identified research that indicates the positive correlation of these traits to effective leadership. Therefore, this study suggests that four variables of Mr. Braddock's 
perspective, i.e., constitute traits that contribute to effective leadership. And if Mr. Braddock's comprehensive leadership role can be defined by both his longevity and his record of service, then the variables of his perspective are significant in relation to his successful leadership.

The fifth variable of Mr. Braddock's perspective, situational context, provides another framework for viewing Mr. Braddock's comprehensive leadership role. A review of the literature, presented Situational Leadership Theory as an another explanation for effective leadership. As was noted previously, the influence of the variables of Mr. Braddock's perspective was evident in the analysis of the elements of his perspective. But while some initiatives such as desegregation were successful, others such as bilingual education were not. This difference in outcomes can be explained by Situational Leadership Theory. Using this theory, results can be understood by an analysis of the interaction between the environmental context of the situation, the individuals involved in the decision making, and the relative influence of the potential leader on the situation. Thus, Mr. Braddock's comprehensive leadership role can be explained as the interaction between person, place and time and provides an understanding of leadership that can be generalized.

Finally, Mr. Braddock's comprehensive leadership role can be assessed as either transactional or transformational. Using Bass and Stodgill's theory of Transactional vs. Transformational Leadership, the other elements of Mr. Braddock's perspective, i.e., teacher professionalization, desegregation, athletics, and bilingual education, provide evidence that Mr. Braddock primarily operated as a transformational leader in his efforts to lead the Miami-Dade Public Schools. With a vision influenced by the variables of his 
perspective, his transformational leadership style was effective in the case of teacher professionalization, desegregation, and athletics. However, compounded by factors related to the situational context, he was not successfully able to lead the bilingual education initiative.

On a secondary level, Mr. Braddock can be viewed as a transactional leader who was well aware of the political realities of the job. As a bureaucrat, he was able to provide effective leadership through daily negotiations with his colleagues on policies of importance. And it was his cognizance of the importance of this aspect of policy making that enabled him to provide effective leadership over the years. Therefore, $\mathrm{Mr}$. Braddock's comprehensive leadership role can be viewed as both transformational and transactional, and it is his ability to successfully negotiate a path between both that makes his leadership both interesting and remarkable.

In summary, the findings of this research were supported by the review of the literature and are significant from a holistic perspective. If one ascribes to the belief that effective leadership stems from personal traits, then the variables of Mr. Braddock's perspective illustrate the importance of fairness, honesty, integrity and courage. However, if one ascribes to the belief that leadership is the result of the interaction of person, place and time, then situational context as a variable of Mr. Braddock's perspective is significant. And finally, if one ascribes to the belief that leadership can be defined as either transformational or transactional, then Mr. Braddock's comprehensive leadership role provides evidence of both.

The significance of these research findings extend beyond Mr. Braddock's experiences with the Miami-Dade County Public Schools. From the analysis of data, the 
study of Mr. Braddock's perspective on his school board career contributes to a general understanding of public education. Using this study, it can be posited that qualities of character, and individual values and beliefs do substantially influence school board policy and educational outcomes. From the example of school desegregation, it was apparent that personal qualities such as fairness, honesty, integrity and courage contributed to the effective leadership that ultimately transformed the Miami-Dade County Public Schools. Additionally, these same personal qualities were cited as contributing to an exceptional term of service. Thus, it can be generalized that effective leadership stems from those variables of Mr. Braddock's perspective identified and discussed in this study. And although this research is particular to the career of one individual, G. Holmes Braddock, the findings suggest that his perspective illuminates a variety of implications for educational leadership that extend beyond the idiosyncratic.

\section{Implications}

While a description of Mr. Braddock's perspective on his school board career is unique to him, the explanation of his perspective can be generalized to other individuals and other settings. Additional research may illustrate this point and several suggestions are listed here:

1. Since Mr. Braddock's longevity was significant in his comprehensive leadership role and distinguished him as being unique in terms of his school board service, it would be interesting to compare him with other urban school board members with long terms of service or contrast these results with a study of other urban school board members with relatively short terms of service. 
2. Several of the elements of Mr. Braddock's perspective represent significant issues of public education policy. Additional research to identify individuals in other urban settings who have played significant leadership roles on some of these same issues would provide additional data to support or refute the influence of the variables of Mr. Braddock's perspective.

3. In this study, several of the secondary sources were former Miami-Dade County school superintendents. It would be interesting to conduct additional research on the role of the superintendency using the same exploratory questions to identify the elements and variables of their perspectives on the superintendency.

4. Using ethnicity as a variable, research on the perspectives of Black or Hispanic school board members on their careers might illustrate the extent of the generalizations that can be made from this study.

5. Since Mr. Braddock and others acknowledged the importance of his participation in state and national school board associations, research on the role that these organizations play in developing or contributing to effective local leadership might prove interesting.

6. As a result of his longevity on the board, Mr. Braddock was able to provide a consistent perspective and exert a constant influence on policy issues. However, many elected officials do not have this opportunity due to term limits. Research on the impact of term limits might offer important insights to public policy outcomes. 
In addition to the implications for future research, other implications for effective leadership in public education can be identified. These implications are listed below:

1. The theme of fairness was an influential variable throughout Mr. Braddock's perspective. This variable is particularly relevant in the realm of public education where an emphasis is placed on providing equal access to educational opportunities for all students. In today's urban school districts, where minority student representation is the majority, school board members should staunchly support initiatives that promote fair and equal access to a quality education.

2. While not clearly evident in this study, there was evidence that the practice of electing school board members from single member districts did not necessarily provide more equitable representation. Rather, some of the evidence suggested that this practice had politicized policy making to a point where there was little regard for the whole district. Additionally, it was suggested that single member districts limited the minority community's influence on policy making. Therefore, it is suggested that the impact of single member districts should be assessed in relation to providing effective public school stewardship.

3. In this study, Mr. Braddock often cited a vision for the future as a critical component of effective school board leadership. Therefore, school boards should regularly engage in visioning activities that transcend the political aspects of the job. 
4. Courage was a word that was often used by others to describe Mr. Braddock, and as illustrated in this study, Mr. Braddock's role in the desegregation of the Miami-Dade County public schools was both courageous and politically suicidal. However, as history demonstrated in this instance, when a course of action is so compelling because it supports some fundamental principle, courage is matter of integrity and honesty. And when faced with the truth of these principles, the political ramifications take care of themselves. Thus, more school board leaders should have the courage of their convictions to do the right thing, rather than doing the thing that will get them re-elected.

5. Mr. Braddock's long school board service illustrated the significance of the personal variables of honesty and integrity. While many politicians are known to tailor their remarks to fit the audience, Mr. Braddock was known to say the same thing to everyone, whether it was popular or not. And even when he was least expected to win another election, he did. This suggests that Mr. Braddock's constituents may not have always agreed with him, but they seemed to have respected his honesty and integrity to "tell it like it is." More politicians should practice this!

6. As pointed out in this study, the line of demarcation between policy and administration was established so that policy makers could establish policy in an environment that was unrelated to its implementation. Recently, this line has become blurred and many school board members are attempting to administer policy rather than develop it. School board members and other 
such policy makers should be reminded of their role as elected public policy officials.

In conclusion, the implications of this study suggest areas for future research and effective public school leadership. And while not inclusive of all potential implications of this research, those discussed here reflect the most salient aspects derived from this study. 


\section{List of References}

Acosta, V. \& Carpenter, L. (2000). Women in intercollegiate sport. A longitudinal study - twenty three year update, 1977-2000. (ERIC Document Reproduction Services No. ED 446 029).

AFT: About AFT. (n.d.). Retrieved May 28, 2001, from http://aft.org/about.

Atkinson, R. (1998). The life story interview. Thousand Oaks, California: Sage Publications.

Bardwick, J. (1996). Peacetime management and wartime leadership. In F. Hesselbein, M., M. Goldsmith, \& R. Beckhard (Eds.), The leader of the future (pp.131-140). San Francisco, California: Jossey-Bass Publishers.

Bass, B. (1990). Bass \& Stogdill's handbook of leadership: theory, research, \& managerial applications $\left(3^{\text {rd }}\right.$ ed.). New York: The Free Press.

Baum, W. (1977). Transcribing and editing oral history. Nashville, Tennessee: American Association for State and Local History.

Berg, B. (1998). Qualitative research methods for the social sciences $\left(3^{\text {rd }}\right.$ ed.). Needham Heights, Massachusetts: Allyn \& Bacon.

Berger, E. (1971, September 20). Braddock: Profile of a man hated... and respected. The Miami News, p. A1, p. A8.

Bialystok, E. (May/June 1999). Cognitive complexity and attentional control in the bilingual mind. Child Development, 70, 636-644.

Black, S. (April 2000). Evaluation for growth. American School Board Journal, 58-61.

Blanchard, L. (1973, December 3). Braddock wants fair guidelines. The Miami News.

Braddock, H. (1973, August 19). Let's complete integration of our schools. The Miami Herald.

Braddock: Some secrecy vital. (1971, February 10). The Miami Herald, p. C7.

Bressan, E. (1980). Multivariate considerations in children's physical education: Social interaction. (ERIC Document Reproduction Services No. ED 177 115).

Brown v. Board of Education. 347 U.S. 483 (U.S.S.C. 1954). 

Brown v. Board of Education of Topeka: 40 years later (June 1993). Woodstock Report.
34, 3-10.

Chase, B. (February 1998). NEA's role. Educational Leadership, p18, p.20.

Contreras, R. \& Stephens, J. (1997). Forty years after Brown: The impact of immigration policy on desegregation. Education and Urban Society, 29, (2) 182-191.

Dahl, R. (1976) Modern political analysis. Englewood Cliffs, New Jersey: Prentice-Hall.

Danzberger, J., Kirst, M., \& Usdan, M., (1996). Governing public schools: New times, new requirements. The Institute for Educational Leadership.

Day, C. (April 2000). Beyond transformational leadership. Educational Leadership, 5659.

Decrane, Jr., A. C. (1996). A constitutional model of leadership. In F. Hesselbein, M., M. Goldsmith, \& R. Beckhard (Eds.), The leader of the future (pp.249-256). San Francisco, California: Jossey-Bass Publishers.

Dentler, R. (1997). Past, present, and future in school desegregation: A review. Equity \& Excellence, 30, (3) 8-12.

Dobosz, R. \& Beaty, L. (1999). The relationship between athletic participation and high school students' leadership ability. Adolescence, 34, (133) 215-220.

Dunaway, D. \& Baum, W. (1996). Oral history: an interdisciplinary anthology. Walnut Creek, California: Altamira Press.

Dutton, S., Singer, J. \& Devlin, A. (1998). Racial identity of children in integrated, predominantly white, and black schools. The Journal of Social Psychology, 138, (1), 41-53.

Eisner, E. (1998). The enlightened eye: Qualitative inquiry and the enhancement of educational practice. Englewood Cliffs, New Jersey: Prentice-Hall.

Farrell, J. M. (1998, November 18). Confusion reigns at school vote. The Miami Herald, A1, A20.

Farren, C. \& Kaye, B. (1996). New skills for new leadership roles. In F. Hesselbein, M., M. Goldsmith, \& R. Beckhard (Eds.), The leader of the future (pp.175-188). San Francisco, California: Jossey-Bass Publishers.

Feldman, S. (1998). AFT's role: Bringing vitality to teaching. Educational Leadership, 19-20. 
Fiedler, T. \& deHaven, L. (1998). The Florida Institute of Government almanac of Florida politics 1998. Iowa: Kendall-Hunt Publishing.

Feiler, R., Heritage, M. \& Gallimore, R. (April 2000). Teachers leading teachers. Educational Leadership, 66-69.

Fritch, W. (1999). An overlooked role of high school athletics: the formation of social capital through parent involvement. (ERIC Document Reproduction Services No. ED 430 290).

Garcia, J. (1981). Field theory in organizational psychology: An analysis of theoretical approaches in leadership. (ERIC Document Reproduction Services No. ED 217 335).

Goodman, F. (1972). Bilingual bicultural education in the Compton Unified School District and its relevance to a multi-ethnic community. (ERIC Document Reproduction Services No. ED 060 705).

Greater Miami Chamber of Commerce. (1997). One community, one goal: Creating jobs for the $21^{\text {st }}$ century - blueprint. Miami, FL.

Greene, K. (January 1990). School board members' responsiveness to constituents. Urban Education, 24, 363-375.

Grodzins, M. (1966). The American system. Illinois: Rand McNally.

Hamilton, N. W. (May-June 1997). Peer review: The linchpin of academic freedom and tenure. Academe, 15-19.

Handy, C. (1996). The new language of organizing and its implications for leaders. In F. Hesselbein, M., M. Goldsmith, \& R. Beckhard (Eds.), The leader of the future (pp.3-10). San Francisco, California: Jossey-Bass Publishers.

Harris, J., Russo, C. \& Brown, F. (1997). The curious case of "Missouri v. Jenkins": The end of the road for court-ordered desegregation? Journal of Negro Education, 66, (1), 43-55.

Hess, G.A. (1998). Un-separate and still unequal? Three books about American education and race at the end of the liberal century. Anthropology \& Education Quarterly, 29, (2) 245-253.

Hesselbein, F., Goldsmith, M. \& Beckhard, R. (1996). The leader of the future. San Francisco, California: Jossey-Bass Publishers.

History of UTD. (n.d.). Retrieved May 27, 2001 from http://utd.org/utdhstry.html. 
Hodgkinson, C. (1991). Educational leadership: the moral art. Albany, NY: State University of New York Press.

Hoffman, A. (1974). Reliability and validity in oral history. In D. Dunaway \& W. Baum (Eds.), Oral history: an interdisciplinary anthology (pp.87-93). Walnut Creek, California: Altamira Press.

Janesick, V. (1998). "Stretching" exercises for qualitative researchers. Thousand Oaks, California: Sage Publications.

Jones, D. (March/April 1998). Bridging the gap between academics \& athletics. Strategies, 9-12.

Joyner, C. (1979). Oral history as a communicative event. In D. Dunaway \& W. Baum (Eds.), Oral history: An interdisciplinary anthology (pp.292-297). California: Altamira Press.

Kerchner, C., Koppich, J. \& Weeres, J. (1998). "New and improved" teacher unionism: But will it wash? Educational Leadership, 21-24.

Kissell, T. (1998, October 22-28). The naming game. Miami New Times, pp. 24-25, pp. $27-28$, p. 31, p. 33 , p. 35, p. 37 , p. 37.

Kouzes, J. \& Posner, B. (1995). Seven lessons for leading the voyage to the future. In F. Hesselbein, M., M. Goldsmith, \& R. Beckhard (Eds.), The leader of the future (pp.99-110). San Francisco: Jossey-Bass Publishers.

Kvale, S. (1996). Interviews: An introduction to qualitative research interviewing. Thousand Oaks, California: Sage Publications.

Leadership: statistics show strength and stability at the helm. (December 1997). American School Board Journal, A15.

Locke, L., Spirduso, W.W. \& Silverman, S. (1993). Proposals that work $\left(3^{\text {rd }}\right.$ ed. $)$. Thousand Oaks, California: Sage Publications.

Marcos, K. \& Peyton, J. (April 2000). Promoting a language proficient society: what you can do. ERIC Digest, 3-4 (ERIC Document Reproduction Services No. ED 441 349).

Margonis, F. \& Parker, L. (1999). Choice: the route to community control? Theory Into Practice, 38, (4) 203-208.

Marshall, C. \& Rossman, G. (1995). Designing qualitative research $\left(2^{\text {nd }}\right.$ ed.). Thousand Oaks, California: Sage Publications. 
Miami-Dade County Public Schools Statistical Highlights. (June 2001). Retrieved June 3,2001 , from http://www.dade.k12.fl.us/9020eema/Highlights\%202000/hilites2000.htm.

Miller, M. (1996). Shared authority in professional education governance: roles and desires of full-time faculty. (ERIC Document Reproduction Services No. ED 409 775.

Mills, C.W. (1959). The sociological imagination. In G. Massey (Ed.), Readings for sociology (pp.13-18). New York: W. W. Norton.

Mintz, S. (1979). The anthropological interview and the life history. In D. Dunaway \& W. Baum (Eds.), Oral history: an interdisciplinary anthology (pp.298-305). Walnut Creek, California: Altamira Press.

Mr. Braddock's lump of truth. (1970, January 22). The Miami Herald.

Mr. Braddock's realism. (1970, September 4). The Miami Herald.

Montone, C. \& Loeb, M., (2000). Implementing two-way immersion programs in secondary schools. Washington D.C.: Center for Applied Linguistics. (ERIC Document Reproduction Services No. ED 439 616).

Nazareno, A. (1999, December 8). Braddock won't seek reelection. The Miami Herald, pp. A1-2.

Nusser, J. (1996). Gender's contribution to the rise and fall of the Progressive Education Association, 1919-1955. (ERIC Document Reproduction Services No. ED 399 340).

Orfield, G. (1997). Does desegregation help close the gap? (Testimony of Gary Orfield, March 22, 1996). Journal of Negro Education, 66, (3) 241-254.

Orfield, G., Arenson, J., Jackson, T., Bohrer, C., Gavin, D. \& Kalejs, E. (1998).

Summary of "city-suburban desegregation: Parent and student perspectives in metropolitan Boston," a report by the Harvard Civil Rights Project. Equity \& Excellence, 31, (3) 6-12.

Orfield, G., Bachmeier, M., James, D. \& Eitle, T. (1997). Deepening segregation in American public schools: A special report from the Harvard Project on School Desegregation. Equity \& Excellence, 30, (2) 5-24.

Pate v. School Board of Miami-Dade County, Florida, 69-1020-CIV (S. D. Fla. 2001). Race, Hispanic or latino, and age: 2000. (2000). Retrieved June 3, 2001 from http://factfinder.census.gov/bf. 
Rasmussen, K. (December 1999/January 2000). The changing sports scene. Educational Leadership, 26-29.

Rubin, H. \& Rubin, I. (1995). Qualitative interviewing: The art of hearing data. Thousand Oaks, California: Sage Publications.

Russo, C. \& Delon, F. (November 1999). Teachers, school boards, and the curriculum: Who is in control? NASSP Bulletin, 22-29.

Saucedo, L. (1997). Parents' attitudes towards dual language immersion programs. (ERIC Document Reproduction Service No. ED 405 730).

School board at turning point. (1978, September 9). The Miami Herald.

School leaders: Board members and superintendents alike feel the pressure of public scrutiny. (December 1996). American School Board Journal, A19-A21.

Scriber, J. \& Layton, D. (1995). The study of educational politics. Washington, D.C.: Falmer Press.

Second language makes sense. (1975, May 2) The Miami News, p. A10.

Seigenthaler, K. L. (1997). Health benefits of leisure. Parks \& Recreation,_24-31.

Senge, P. (1995). Leading learning organizations: the bold, the powerful and the invisible. In F. Hesselbein, M., M. Goldsmith, \& R. Beckhard (Eds.), The leader of the future (pp.41-58). San Francisco, California: Jossey-Bass Publishers.

Silliker, S. A. \& Quirk, J. T. (1997). The effect of extracurricular activity participation on the academic performance of male and female high school students. The School Counselor, 44, 288-293.

Simons, H., Van Rheenen, D. \& Covington, M. (1999). Academic motivation and the student athlete. Journal of College Student Development, 40, (2), 151-162.

Sockett, H. (May 1996). Teachers for the $21^{\text {st }}$ century: redefining professionalism. NASSP Bulletin, 80, 22-29.

Southerner says busing opponents are liars. (1970, January 22). Education Daily, 3, (14), p.2.

Starr, L. (1977). Oral history. In D. Dunaway \& W. Baum (Eds.), Oral history: an interdisciplinary anthology (pp.39-61). Walnut Creek, California: Altamira Press. 
Stevens, L. (1997). Conventional wisdom and school desegregation. Equity \& Excellence, 30, (3) 5-7.

Stichler, R. (May-June 1997). Academic freedom and faculty responsibility in disciplinary procedures. Academe, 20-22.

Strope, J. (November 1999). Academic freedom: In our minds, the legal myth dies slowly! NASSP Bulletin, 14-21.

Sullivan, K., Lantz, P. \& Sirkel, P. (2000). Leveling the playing field or leveling the players? The Journal of Special Education, 33, (4) 258-267.

Torriero, E.A. (1978, July 23). It's no secret West Kendall schools overcrowded. The Miami Herald, p. 16-18.

Trent, W. (1997). Outcomes of school desegregation: findings from longitudinal research. Journal of Negro Education, 66, (3) 255-257.

Tucker, R. (August 1999). A global perspective on bilingualism and bilingual education. ERIC Digest, 2-4 (ERIC Document Reproduction Services No. ED 435 168).

Webster's new collegiate dictionary. (1976). Springfield, MA: Merriam-Webster.

Webster's II new riverside dictionary. (1984). New York: Houghton Mifflin.

Weiler, J. (April 1998). Recent changes in school desegregation. ERIC Clearinghouse on Urban Education, 3-6.

Willie, C. (January 1999). Integration: speaking the painful truth. Black Issues in Higher Education, 24-25.

Wirt, F. \& Kirst, M. (1992). The political dynamics of American education. California: McCutchan Publishing.

Wolcott, H. (1994). Transforming qualitative data: description, analysis, and interpretation. California: Sage Publications.

Work, J. (1996). Leading a diverse work force. In F. Hesselbein, M., M. Goldsmith, \& R. Beckhard (Eds.), The leader of the future (pp.71-80). San Francisco, California: Jossey-Bass Publishers.

Wright, C. (1969, September 5). Man on the hottest seat in town. The Miami News, p. A1, Al3. 
Yon, M., Nesbit, C. \& Algozzine, B. (1998). Racial and social class isolation in magnet schools. Journal of Research in Childhood Education, 13, (1) 77-84.

Yow, V. (1994). Recording oral history: a practical guide for social scientists. Thousand Oaks, California: Sage Publications.

Zaugg, H. (1998). Academic comparison of athletes and non-athletes in a rural high school. NASSP Bulletin, 82, (599), 63-72. 
Appendix 1 - Biography of G. Holmes Braddock 


\section{G. Holmes Braddock}

5029 S.W. 151 Place

Miami, Florida 33185

\section{$\underline{\text { School Board Service }}$}

Member of the Miami-Dade County School Board for thirty-eight years. First elected in 1962, re-elected 9 times and retired in 2000.

Served as Chairman of the board seven times

Served as Vice-Chairman of the board six times

Member of the Council of Great City Schools Executive Committee and filled the various offices becoming President in 1990-91.

Elected to the Board of Directors, National School Boards Association for two terms, 1990-1996.

Member of the National School Boards Association Nominating Committee, 1985 and 1988.

Member of the Florida School Boards Association and filled the various offices becoming President in 1985-86.

Chairman, 1972-73, of the Council of Urban Boards of Education of National School Boards Association.

\section{Educational Consulting}

Apple Computer, Restructuring

Union Carbide, Restructuring

Education Commission of the States, Restructuring Task Force

Chicago Public Schools, Restructuring and Board Statesmanship

Benton Harbor Public Schools (Michigan), Desegregation

National Conference of State Legislatures, Restructuring 


\section{Professional Background}

Chartered Life Underwriter

Qualifying Member, Million Dollar Round Table

Resident Manager, Jefferson-Pilot Life Insurance Company

General Agent, Midland Mutual Life Insurance Company

Assistant General Agent, Massachusetts Mutual Life Insurance Company

Manager, Miami Shores Country Club

Assistant to Director of Admissions, University of Miami

Manager, Student Union, University of Miami

\section{Education}

Vero Beach High School, Vero Beach, Florida

Bachelor of Arts Degree, University of Miami

Master of Education, Human Relations, University of Miami

\section{Civic Membership and Activities}

Member Kendall United Methodist Church

Touchdown Club of Miami (past president and former member of Board of Directors). Presently serving as an ex-officio member of the Board.

University of Miami Sports Hall of Fame committee

Coached Khoury League baseball, Optimist football, and American Legion Baseball

\section{$\underline{\text { Honors }}$}

Whitney M. Young, Jr. Memorial Humanitarian Award, Greater Miami Urban League

Outstanding Service Award, Omega Psi Phi Fraternity

Man of the Year Award for Service to Education, Phi Delta Kappa

School Bell Award, Outstanding Citizen of Florida, Florida Education Association

Award for Outstanding Contributions to Education, Dade County School Administrators Association

National Committee for Middle East Studies in Secondary Education

Sara T. Maddox Support of Art Award 
Commission for Bilingual Education Award

Florida Commissioner of Education's Study Tour of Japan

“The President's Award: Outstanding School Board Member" Florida School Boards Association

G. Holmes Braddock Scholar, College Assistance Program

Distinguished American Award, Miami Chapter, National Football Foundation

Richard R. Green Award for "Contributions to Urban Education," Council of Great City Schools

Certified School Board Member, Florida School Boards Association

G. Holmes Braddock Annual Scholarship Award, Council of Great City Schools

Also during tenure on the School Board testified before the Senate Select Sub-committee on Equal Education Opportunity and the House Sub-committee on Education. Also served as chairman and/or panelist on many clinics held during National School Boards Association conventions.

Born in Forsyth, Georgia and lived entire life in Florida. Served in World War II on Army hospital ship the Frances Y. Slanger.

Married, wife's name is Virginia. Has four grown children from former marriage and seven grandchildren. 
Appendix 2 - Interview Guide 


\section{INTERVIEW GUIDE}

\section{PERSONAL ATTRIBUTES, INFLUENCES AND/OR CONTRIBUTIONS}

What prompted you to become involved in school board politics?

What are the motivating factors that have influenced your career on the school board?

What have been your most significant contributions?

What have been your failures?

How do you want to be remembered?

What is it like to have a high school named after you?

How do you measure success?

\section{RESPONSIBILITIES AND ROLE OF A SCHOOL BOARD MEMBER}

What is a typical day like?

How many hours a week do you spend on school board business? Does it vary? Why?

What types of personal costs have you experienced as a result of your public office?

Tell me about your years as chairman.

How do you perceive your role as a school board member?

Who do you answer to?

How do you handle personal requests from parents and other constituents?

How do you make decisions? What do you consider? Who do you consider? How do you ensure that your decisions are acted upon?

Tell me about the agenda and policy making process.

What have been some of the most significant policies initiated during your tenure?

What are important issues for you presently?

What is the role of the superintendent? 
How has the role of the superintendent changed?

\section{POLITICAL ASPECTS}

How do you become a school board member?

How is campaigning different today than it was at the beginning of your career?

How often were you contested? Did this change your method of campaigning?

How have things changed politically during your tenure?

What do you think of the new board composition and single member districts?

\section{LEADERSHIP}

What qualities make a good leader?

What attributes are most important to effective leadership?

Whom do you view as an effective leader? Why?

Having said that about others, do you see yourself as a leader? Why?

What qualities do you possess that enhance your leadership abilities?

When have you demonstrated leadership?

When would others say that you have demonstrated leadership?

Who has been the most effective leader involved with the school system in your time? Why?

Describe the superintendents during your tenure. What have been their greatest achievements? What do you think made them successful or not?

Who have been the most effective board members during your tenure? Why?

What school board employees, board members, or affiliates would have personal knowledge of your involvement with Dade County and would be willing to speak with me? 
Appendix 3 - Consent Form 
CONSENT FORM

I, G. Holmes Braddock, agree to participate in this study with Elizabeth Ferreira-Alves. I realize that no harm will come to me and that this information will be used for educational purposes. I understand that I may withdraw from the study at any time.
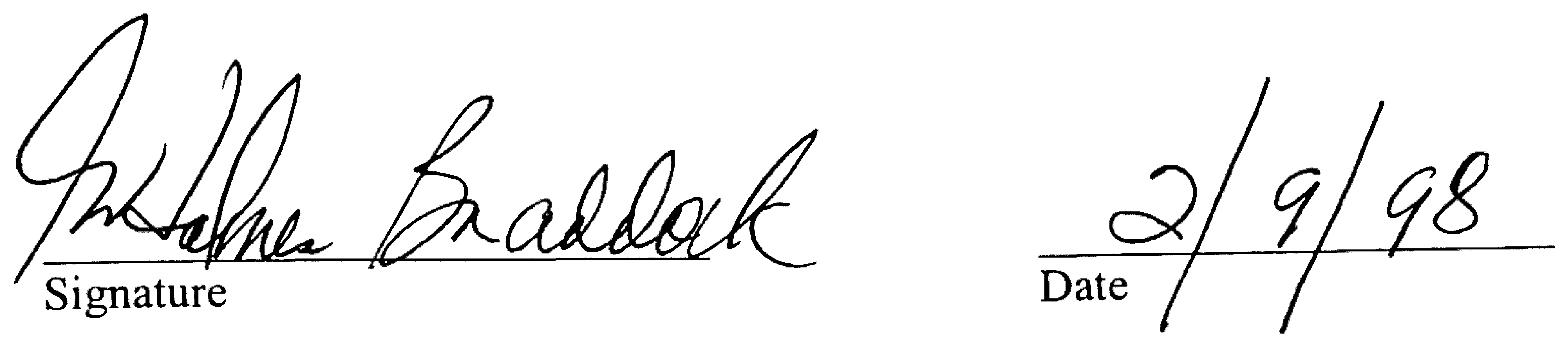

175 
Appendix 4-Affirmation of Intent 


\section{AFFIRMATION OF INTENT}

I, Elizabeth Ferreira-Alves, am conducting a dissertation study that seeks to describe and explain Mr. G. Holmes Braddock's perspective on his career as a Miami-Dade School Board member. This study is for educational purposes only and all interview data will be presented as accurately as possible. You have the right to withdraw from this study at any time.

Signed

Date 


\section{VITA}

\section{ELIZABETH ANN FERREIRA-ALVES}

October 11, 1960

2000-present

$1997-2000$

1996-1997

1991-1995

1989-1996

1989-1991

1988-1989

1985-1989
Born, Washington, D.C.

Principal

Cutler Ridge Middle School

Miami, Florida

Assistant Principal

Coral Reef High School

Miami, Florida

Assistant Principal

Mays Middle School

Miami, Florida

Adjunct Professor

Miami-Dade Community College

Miami, Florida

English Teacher

Mays Middle School

Miami, Florida

M.S., English Education

University of Miami

Coral Gables, Florida

English Teacher

Redland Middle School

Miami, Florida

B.A., English

Florida International University

Miami, Florida

\section{PRESENTATIONS}

Orlando, Florida, Southern Association of Colleges and Schools, "How Do You

Dance When the Music Stops?" 
Orlando, Florida, Florida Association of School Administrators State Conference, "The ABC's of Becoming an A-Rated High School"

Orlando, Florida, Southern Association of Colleges and Schools, "Lessons Learned"

Orlando, Florida, Southern Association of Colleges and Schools, "Building a School Community from the Ground Up"

Orlando, Florida, National Council of Teachers of English, "Reflections: A Multicultural Oral History"

Miami, Florida, Dade County Council of Teachers of English, "Reflections: A Multicultural Oral History"

Key Largo, Florida, Billy Birnie and Associates, "Interdisciplinary Teaching in the Middle School"

Vail, Colorado, Association of Supervision and Curriculum Development, "A Model for Interdisciplinary Teaching and Learning" 